UNIVERSIDADE DE SÃO PAULO

FACULDADE DE FILOSOFIA, LETRAS E CIÊNCIAS HUMANAS DEPARTAMENTO DE GEOGRAFIA

PROGRAMA DE PÓS-GRADUAÇÃO EM GEOGRAFIA URBANA

Adailton Isidro de Deus

A BERRINI NA CENTRALIDADE DE SÃO PAULO

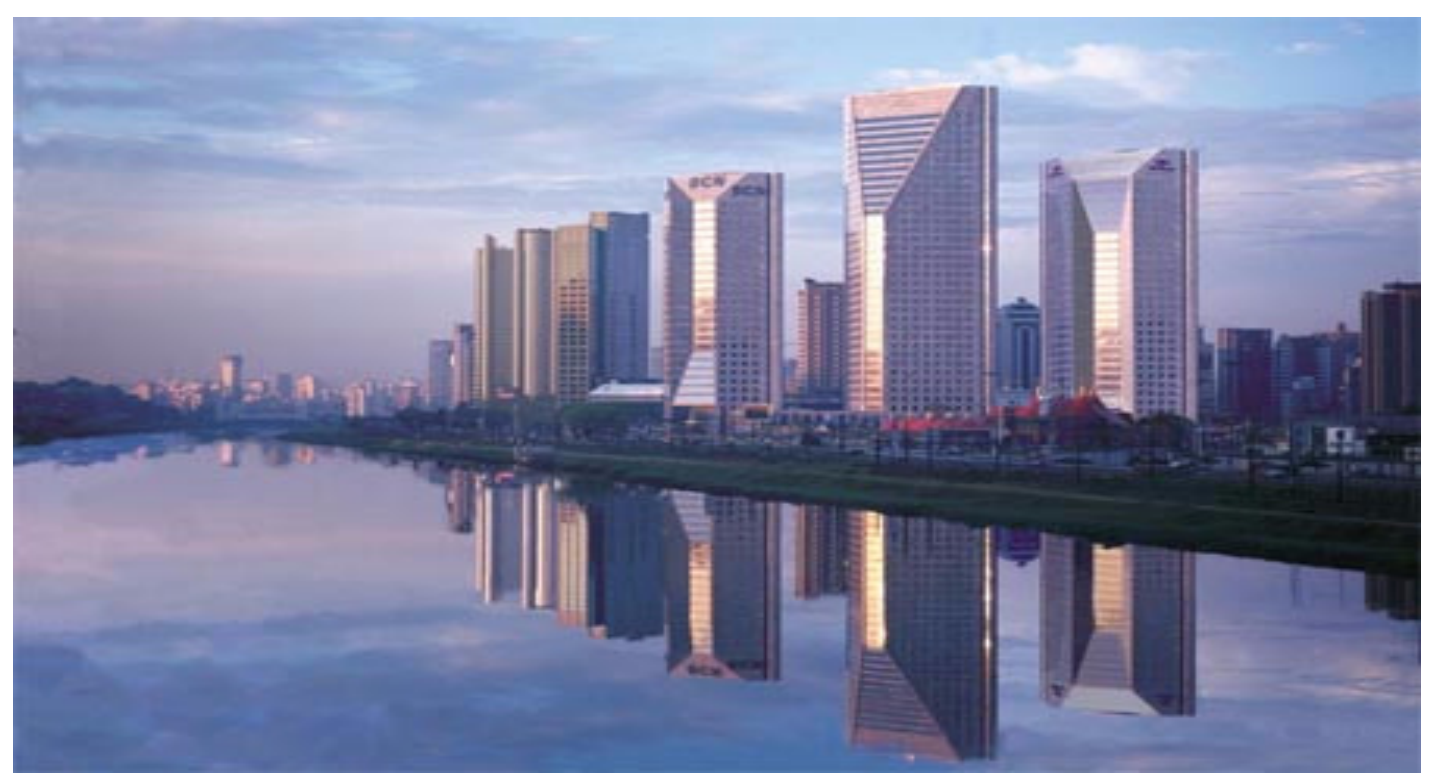

São Paulo 2007 


\author{
UNIVERSIDADE DE SÃO PAULO \\ FACULDADE DE FILOSOFIA, LETRAS E CIÊNCIAS HUMANAS \\ DEPARTAMENTO DE GEOGRAFIA \\ PROGRAMA DE PÓS-GRADUAÇÃO EM GEOGRAFIA URBANA
}

\title{
A BERRINI NA CENTRALIDADE DE SÃO PAULO
}

Adailton Isidro de Deus

Dissertação de Mestrado apresentada ao Departa mento de Geografia da Faculdade de Filosofia, Le tras e Ciências Humanas da Universidade de São Paulo, para obtenção do título de Mestre em Geografia

Orientadora: Profa. Dra. Glória da Anunciação Alves

São Paulo 2007 


\section{RESUMO}

Esta dissertação procurou localizar, identificando e analisando por meio do espaço, como a espacialização da globalização econômica (setor financeiro e de serviços) na cidade de São Paulo, especificamente no centro Berrini, contribuiu para fragmentar ou para desdobrar a centralidade de São Paulo.

Nosso objeto de pesquisa foram as possíveis relações e os impactos que o Centro Berrini considerado como uma área das mais recentes na cidade de São Paulo a concentrar um significativo afluxo de investimentos para escritórios de empresas transnacionais, "um centro de negócios mundial", estabeleceu e desencadeou provocando ou não transformações em relação ao Centro e a centralidade da Cidade de São Paulo.

A globalização da economia influenciou em várias cidades mundiais a formação ou criação de centros com as chamadas atividades do Terciário Moderno (setor de serviços e financeiro) de forma muito semelhante ao que ocorre no Centro Berrini. No entanto, mesmo com o afluxo de investimentos globais, sua gênese não pode ser entendida sem a articulação com o processo de crescimento e expansão urbana da cidade, o desdobramento de sua centralidade que continua a acontecer, de tal forma, que a centralidade expande alcançando áreas que antes eram consideradas como fazendo parte da periferia.

O resultado é um novo conflito sócio - espacial induzido por um modelo de produção em que a centralidade econômica ocupa espaços antes periféricos. $\mathrm{E}$, de forma contraditória e desigual, nesses espaços parcelas da população tenta resistir e às vezes incorporando ações e valores do próprio modelo que a produziu.

\section{PALAVRAS-CHAVE}

Globalização; Espacialização; Centro; Centralidade; Desdobramento; Periferia. 


\begin{abstract}
This dissertation is centred upon identifying and analysing through the space idea how the economic and global spaciousness (financial and trade centres) at São Paulo city, specifically at Berrini center, had been contributing to fragment or increase São Paulo's centrality.

Our research's object focus the possibles relations and impacts that the Berrini centre, considered as the newest area in the city of São Paulo that concentrates a significative investment affluences to world-wide business offices, "a world business center", had established and incremented by causing or not transformations between the Centre itself and the centrality of São Paulo.

The economic globalization had influenced on many cities of the world the formation or creation of centers whose activities is kown as Modern Third (trade and financial sectors) in the same way that occurs at Berrini centre. Otherwise even with the global investments affluences its genesis can't be understand without the articulation with the growing process and the urban expansion of the city, the improvement of its centrality that's still being done in such a way that the centrality increases reaching out areas that former were considered as being part of periphery.

So the consequence is a new spacious and social conflict induced by a production model where the economic centrality occurs in spaces before considered peripheral. And in a contradictory and unequal way on these spaces some kind of the population intends to resist by incorporating sometimes moral principles and actions of the same model that had created it.
\end{abstract}

\title{
WORD-KEYS
}

Globalization, Spacialization, Centre, Centrality, Increasing, Periphery 


\section{AGRADECIMENTOS}

A realização desta dissertação só foi possível devido à colaboração de muitas pessoas que, por caminhos diversos, com argumentos, ou afetivamente acompanharam passo a passo e de maneira crítica minha pesquisa. São fundamentais a Profa. Dra. Glória da Anunciação Alves que tornou viável o suporte intelectual e possibilitou a vivência com meus colegas de colóquios: Ana, Sandra, Nanci, Aglaé, Neide, Maria Ângela, Emerson, Wilson, Kleber, Sandro, Michel e Nedir.

Faço uma dedicação especial à minha companheira Nilza e às minhas filhas Luísa e Marina pacientes e compreensivas nas minhas ausências.

Minha gratidão aos meus pais e agradeço com muito carinho à minha irmã Eloaine que nos momentos finais esteve presente e companheira.

A todos os professores que contribuíram em minha formação.

Em memória de Eliana Sergia de Andrade 
Nome do arquivo: UNIVERSIDADE DE SÃO PAULO

Pasta:

C:IDocuments and Settings\Adailton\Meus documentos

Modelo:

C:IDocuments and Settings\Adailton\Dados de aplicativos $\backslash$ Microsoft $\backslash$ Modelos $\backslash$ Normal.dot

Título:

UNIVERSIDADE DE DÃO PAULO

Assunto:

Autor:

Adailton Isidro de Deus

Palavras-chave:

Comentários:

Data de criação:

$19 / 6 / 200718: 29$

Número de alterações:8

Última gravação: $\quad$ 28/6/2007 08:17

Gravado por: $\quad$ Adailton Isidro de Deus

Tempo total de edição: $\quad 73$ Minutos

Última impressão: 28/6/2007 08:18

Como a última impressão

Número de páginas: 5

Número de palavras: 742 (aprox.)

Número de caracteres: 4.230 (aprox.) 


\section{Sumário}

Índice de mapas

02

Introdução

03

A Berrini: A globalização da várzea

Da Capela Jesuíta à Centralidade São Paulo.

Os agentes hegemônicos.

Os agentes não hegemônicos: resistência ou inserção na mesma lógica de produção?

Considerações Finais

Referências bibliográficas 


\section{Índice de Mapas}

Mapa 1 - Origem de investimentos anunciados Brasil 1997/2003

Mapa 2 - Produto Interno Bruto Unidades da Federação e Região Metropolitana de São Paulo 2003.

Mapa 3 - Subprefeituras e Distritos do Município de São Paulo - Localização do Centro e da Berrini.

Mapa 4 - Operação Urbana Água Espraiada - localização da Berrini.

Mapa 5 - Estabelecimentos, segundo setores de atividades - Distrito do Município de São Paulo.

Mapa 6 - Lançamentos Comerciais no Mercado Imobiliário - Município de São Paulo.

Mapa 7 - Salas de Teatro, Shows e Concertos - Município de São Paulo.

Mapa 8 - São Paulo - Centro - em 1824 e 2004

52

Mapa 9 - Butantã - Uso e Ocupação do Solo - Localização Favela da Mandioca Zona Especial de Interesse Social.

Mapa 10 - localização do Projeto Casulo, EMEI Pero Neto e Favela da Mandioca / Real Parque/Morumbi. 


\section{A Berrini na Centralidade de São Paulo.}

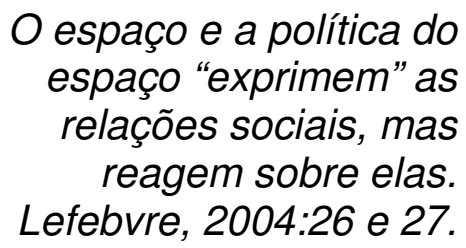

\section{Introdução}

Estamos partindo, neste estudo, da hipótese de que a espacialização da globalização produziu e está produzindo transformações na metrópole de São Paulo contribuindo para que esta centralidade, no caso a cidade de São Paulo, seja o que é atualmente, a denominada "cidade dos negócios" e "cidade mundial", reforçando sua importância como Centro regional e mundial.

Os mapas 1 e 2 demonstram que São Paulo recebe afluxos de investimentos de todos os continentes, com destaque para os investimentos norte-americanos e europeus, no entanto, a concentração dos investimentos externos combinados com os índices do PIB demonstra uma polarização do município e de sua região metropolitana, na medida em que o Produto Interno Bruto - PIB do município de São Paulo supera o de alguns estados.

Esta condição de centralidade produziu em São Paulo uma metrópole na qual a complexidade engloba desde formas precárias de moradias que compõem suas inúmeras favelas, passando por luxuosos condomínios residenciais até os modernos edifícios tecnológicos, em uma paisagem que possui tanto o catador de latinhas de alumínio/papelão ou sucata, com sua carroça, disputando espaço ao lado de automóveis importados de última geração, quanto o pedinte na calçada, o alto executivo de uma multinacional que sobrevoa a cidade nos helicópteros, a vendedora de cachorro quente, o motoboy, o operário, o desempregado, o político, o consumidor...

Tal é a complexidade da metrópole São Paulo que não temos como capturar sua totalidade, mas podemos dizer que nesta centralidade (a cidade como centro) aconteceu intensa concentração de riqueza e pobreza que não pôde ficar restrita em um único centro inserido na cidade, ou seja, ao centro, que no 
Mapa 1.

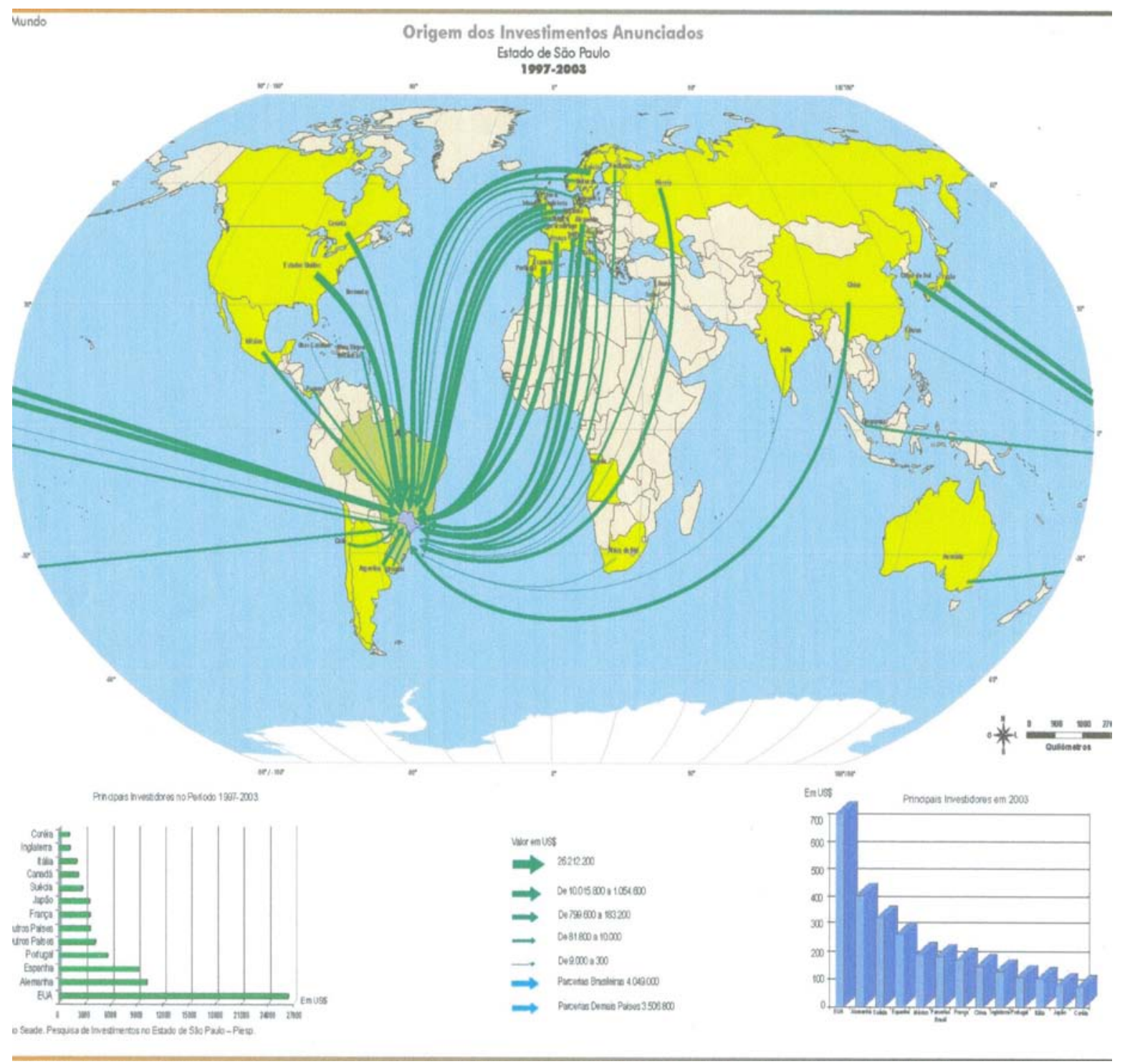


Mapa 2.

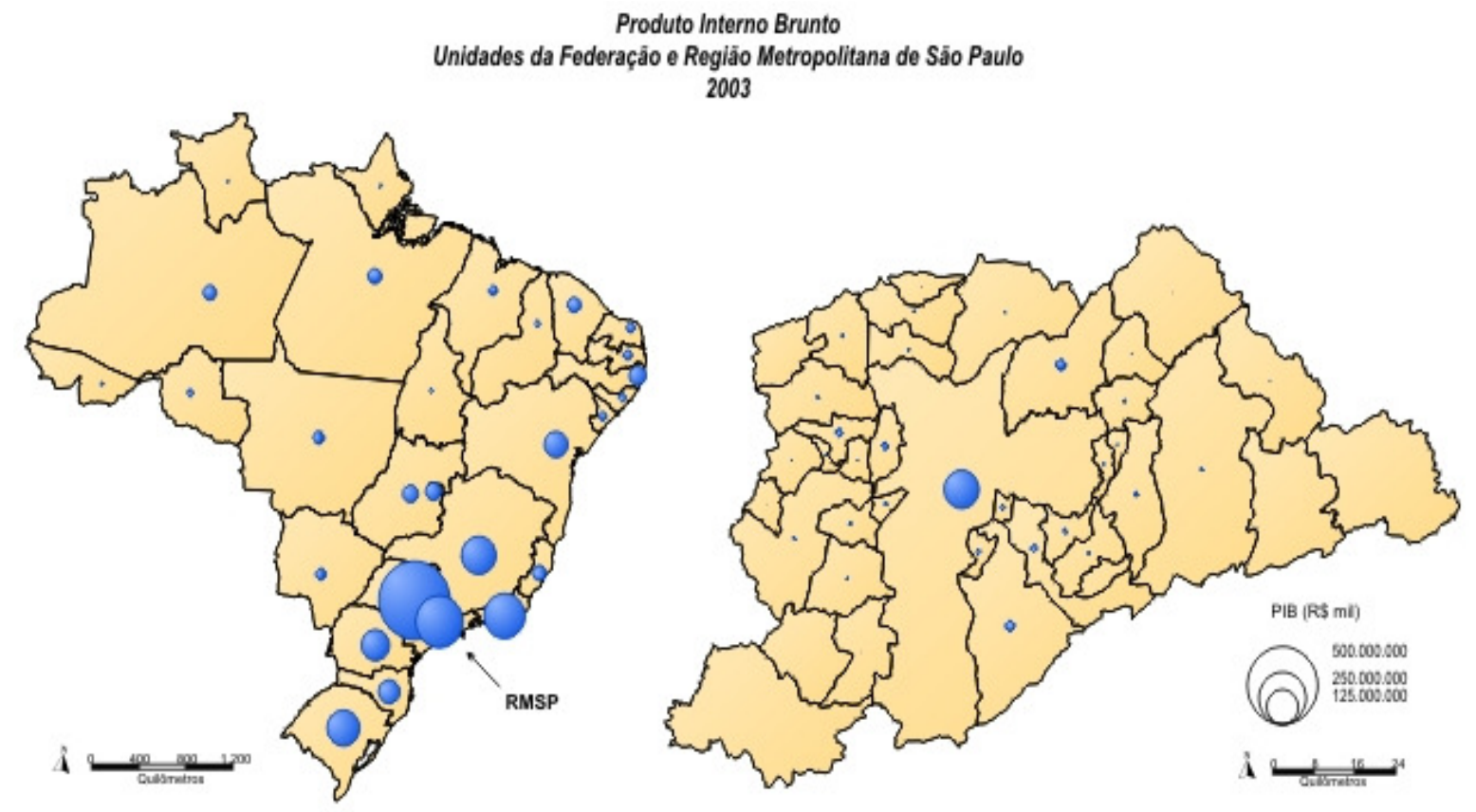


caso de São Paulo, correspondia ao que hoje se denomina de centro histórico ${ }^{1}$ (denominado de antigo para alguns e velho para outros). Já há algum tempo este centro se saturou, com 0 acúmulo de atividades, trocas, objetos, pessoas, relações diversas num mesmo lugar, o que provocou, em um primeiro momento, seu desdobramento quando houve a necessidade de:

adaptação do Centro às novas determinações exigidas pelas condições econômicas, ideológicas e políticas do estágio industrial pelo qual a cidade passou no período aproximado de 1920 a 1950. Assim, quando nos referimos a um " processo de desdobramento", queremos dizer que a cidade para se adaptar à nova economia de produção necessitou de um novo espaço para albergar suas construções representativas e funcionais fora das áreas congestionadas dos centros velhos que ficaram pouco atraentes aos olhos de alguns setores sociais". (TOURINHO, 2004: 338)

Destacamos que o desdobramento do Centro foi parte de um contexto induzido por um processo industrial, na medida em que "a cidade para se adaptar à nova economia de produção necessitou de um novo espaço". Posteriormente ao desdobramento em centro antigo e centro novo, o adensamento do Centro (denominamos Centro - com a inicial maiúscula - deste momento em diante ao espaço constituído pelo centro velho e o centro novo) continuou em ritmo maior, fazendo com que o congestionamento das atividades, dos serviços e da circulação se tornasse um problema, como que implodindo o Centro, inviabilizando a concentração de algumas atividades - assim parte destas atividades e serviços se espalharam (estilhaçadas) ${ }^{2}$ pela cidade - como se explodindo em novas áreas de centralidade. Para alguns autores como Helena Cordeiro, houve o desdobramento e tresdobramento da nucleação do Centro Metropolitano de São Paulo ${ }^{3}$.

\footnotetext{
${ }^{1}$ que englobava espaços como Praça da Sé, Pátio do Colégio, Largo São Francisco, Praça João Mendes, Largo da Memória, Largo São Bento, ruas XV de Novembro, Direita, Florêncio de Abreu e São Bento denominado de triângulo histórico.

${ }^{2}$ Estilhaçadas porque são fragmentos, uma parte da mesma atividade/serviço originária do Centro que foi espacializada em outro lugar (nova área de centralidade), mas mantém/necessita de uma ligação/relação com o Centro.

3 Helena Khon Cordeiro. A "cidade mundial" de São Paulo e o complexo corporativo de seu centro metropolitano. Neste texto a autora expõe o tresdobramento da nucleação do Centro Metropolitano de São Paulo, daí os termos: centro Principal (ou Tradicional), centro Paulista e centro Berrini que considero como as partes que formam a centralidade São Paulo.
} 
Concordando inicialmente com Cordeiro, reconhecemos que ocorreu em um primeiro momento o desdobramento do Centro de São Paulo em um processo, que destacamos, foi induzido pela industrialização. No entanto, em um segundo momento, não é o Centro que se desdobra, mas sim sua centralidade com o estilhaçamento de algumas atividades e serviços que estavam condensadas no Centro. Nossa segunda hipótese é a de que a flexibilização produtiva da economia induziu o processo que fez estilhaçar algumas atividades e serviços concentrados no Centro produzindo o desdobramento em novas áreas de centralidade econômica, contribuindo para a policentralidade da metrópole.

Contudo, essas novas áreas de centralidade econômica que resultam do desdobramento do setor terciário, não são, ainda, centralidades plenas como o Centro que "supõe e propõe a concentração de tudo o que existe no mundo, na natureza, no cosmos: frutos da terra, produtos da indústria, obras humanas, objetos e instrumentos, atos ou situações, signos e símbolos" (LEFEBVRE, 2004:46). No processo urbano, consideramos que as novas áreas de centralidade econômica são, por enquanto, centralidades relativas em formação.

$E$, para explicitarmos o estilhaçamento e desdobramento de algumas atividades do Centro, nossa análise precisa referenciar que estamos fazendo uso do termo - espacialização - porque entendemos que seja de fundamental importância para tratar do processo de produção da centralidade em São Paulo. Aceitando que a centralidade urbana proveio do que:

os estudiosos chamam há algum tempo de divisão social do espaço. Quer dizer, à medida que há distintas atividades e distintos níveis sociais ligados a estas atividades, esta divisão se espacializa e, ao espacializar-se, tem, a um só tempo, elementos de diferenciação, tanto a nível social como espacial (CASTELLS apud SPOSITO: 1991:7).

Podemos entender, então, que no contexto da divisão social do espaço, a produção de uma nova área de centralidade refere-se, portanto, ao processo como as diferentes atividades decorrentes dos diferentes níveis sociais são configuradas concretamente no território, quer dizer são espacializadas e, assim, "descobrimos o essencial do fenômeno urbano na centralidade. Mas na 
centralidade considerada com o movimento dialético que a constitui e a destrói, que a cria ou a estilhaça" (LEFEBVRE, 2004:110).

É ao movimento dialético que cria e estilhaça a centralidade que nos referenciamos para contextualizar o processo urbano na cidade de São Paulo, porque em seu Centro, subcentros e "novos centros"4 as atividades e serviços continuam sendo produzidos e reproduzidos em um ritmo crescente e acumulativo neste espaço e, desse modo, deverá causar a saturação e posterior estilhaçamento da centralidade produzindo seu desdobramento em novas espacializações territoriais, ao mesmo tempo, requerendo um Centro como referência, apoio e identidade. Nesse movimento, do fenômeno urbano, apontamos a hipótese de que os "novos centros" necessitam do Centro e reforçam sua centralidade estabelecendo uma relação contraditória de competição e complementaridade simultâneas.

Como as atividades são espacializadas no território, podemos inferir que existem os agentes indutores da produção de mercadorias tradicionalmente reconhecidos como ligados às atividades industriais, e outros, como os agentes imobiliários e financeiros que atuam no processo de espacialização ao interferir no processo produtivo, impondo novas formas espaciais. Assim o capital por meio dos vários agentes indutores realiza a todo o momento ações planejadas em relação ao uso do espaço com o intuito de reprodução do capital na produção do espaço urbano.

O reconhecimento da existência dos agentes indutores na reorganização do espaço permite a colocação de que a expansão do capital em escala global, ao penetrar nos territórios nacionais também interfere na produção e reprodução desta centralidade e a modifica, causando a transformação de função, ou sua transição, onde a coexistência de uma nova função junto às anteriores que serão substituídas e/ou alterada, traz como conseqüência a criação ou reprodução de formas (arquiteturais e/ou urbanísticas) em sua morfologia prático-sensível imediata: a realidade presente, que se pode ver, sentir e tocar.

\footnotetext{
${ }^{4}$ Utilizamos o termo para diferenciar do Centro e subcentros porque estes novos centros não são agregadores, ainda, de múltiplas funções e relações, são centros relativos em formação.
} 
É possível que na Metrópole de São Paulo esteja acontecendo a espacialização da globalização (considerada para alguns autores, como Sassen, uma cidade mundial), mais especificamente na sua centralidade, na qual, destacamos o Centro, o centro Paulista, o centro Faria Lima e o centro Berrini onde a implantação de um modelo de produção flexível centrado em atividades do terciário moderno está substituindo o modelo fordista de base industrial ${ }^{5}$. Aqui reafirmamos nossa segunda hipótese de que o centro Berrini pode ser um desdobramento da centralidade de São Paulo, tendo sido resultado da indução da flexibilização produtiva, ou seja, trata-se de um tipo de desdobramento que não requer a contigüidade física, na medida em que os avanços tecnológicos e de transporte permitem as proximidades necessárias. Para Lencioni:

Nesse processo em que a metrópole de São Paulo conhece uma desindustrialização relativa, afirma-se, cada vez mais, a cidade de São Paulo como centro de serviços, informação, gestão, coordenação e controle do capital (2004:161)

A afirmação de São Paulo como centro de serviços, informação, gestão, coordenação e controle do capital impõe um outro ritmo e organização produtiva requerendo outros arranjos espaciais diferentes do modelo industrial e é nesse sentido que destacamos a importância em entender este processo através da análise das transformações urbanas que são produzidas e reproduzidas na centralidade de São Paulo podendo contribuir para revelar a nova concepção de sociedade que se reproduz, se levarmos em conta que:

... a cidade é obra, a ser associada mais com a obra de arte do que com o simples produto material. Se há uma produção da cidade, e das relações sociais na cidade, é uma produção e reprodução de seres humanos por seres humanos, mais do que uma produção de objetos... (LEFEBVRE, 2001:46 e 47)

Assim, concordamos com Lefebvre, a cidade é mais do que um simples artefato ou um objeto. Está mais próxima da obra de arte enquanto uma produção

\footnotetext{
${ }^{5}$ David Harvey. Condição pós-moderna. A acumulação flexível (...)se apóia na flexibilidade dos processos de trabalho, dos mercados de trabalho, dos produtos e padrões de consumo. Caracteriza-se pelo surgimento de setores de produção inteiramente novos, novas maneiras de fornecimento de serviços financeiros, novos mercados e, sobretudo taxas altamente intensificadas de inovação comercial, tecnológica e organizacional. A acumulação flexível envolve rápidas mudanças dos padrões do desenvolvimento desigual tanto entre setores como entre regiões geográficas, criando, por exemplo, um vasto movimento no emprego no chamado "setor de serviços"...p.140
} 
da sociedade que se reproduz espacialmente e, mesmo que nos dê a impressão de espelho, a cidade não se repete: além do concebido - projetado, calculado, enquadrado -, existe o vivido, as relações diárias nos vários níveis sociais que podem romper o enquadramento. Por isso, propomos estudar a centralidade de São Paulo buscando perceber o movimento de reprodução mundial do capital que interfere em sua produção e reprodução. Contribui, nesse sentido, o entendimento de que a globalização se refere:

às mudanças decorrentes dos processos produtivos que, ao se realizarem, em seu processo de expansão, derrubam barreiras e fronteiras nacionais ligando, ao mercado, os 'lugares do mundo'... (CARLOS, 2004:48)

E, como os processos produtivos possuem essa dinâmica que impõe a derrubada de barreiras e fronteiras nacionais, o processo atual de globalização produtiva torna-se relevante em relação ao espaço porque ao mesmo tempo em que requer toda uma infra-estrutura local (circulação, comunicação, etc.), também impõe a implantação de novas formas - instrumentos (edifícios inteligentes) modificando a centralidade, criando formas concretas visíveis na sua arquitetura e traçado urbano. Nesse sentido a espacialização da globalização em São Paulo fragmenta ou concentra sua centralidade?

É no contexto de que "as relações sociais de produção são formadoras e contingentes ao espaço"6 que retomamos as categorias de produção e reprodução do capital como fundamentais para explicar a atual centralidade urbana em São Paulo, porque:

Ninguna sociedad puede dejar de consumir, ni puede tampoco, por tanto, dejar de producir. Por consiguiente, todo proceso social de producción considerado en sus constantes vínculos y en el flujo ininterrumpido de su renovación es, al mismo tiempo un proceso de reproducción. (MARX, 1999: $52)^{7}$

\footnotetext{
${ }^{6}$ Edward Soja. Geografias pós-modernas “A noção fundamental introduzida por Lefebvre (...) de que as relações sociais e espaciais são dialeticamente inter-reativas, interdependentes; que as relações sociais de produção são formadoras do espaço e contingentes ao espaço". p. 103

7 Tradução do autor: Nenhuma sociedade pode deixar de consumir, nem pode tão pouco, portanto, deixar de produzir. Por conseguinte, todo processo social de produção considerado em seus constantes vínculos e no fluxo ininterrupto de sua renovação é, ao mesmo tempo, um processo de reprodução.
} 
Ao considerarmos que as centralidades urbanas são parte do movimento das relações sociais de produção e reprodução, ao mesmo tempo em que essas relações são contingentes ao espaço produzido, posicionamos o objetivo nesta pesquisa em analisar e entender como a espacialização da globalização econômica (setor financeiro e de serviços), na cidade de São Paulo, especificamente no centro Berrini, pode estar contribuindo para fragmentar ou para expandir e concentrar a centralidade de São Paulo.

É a partir das transformações, em especial das que estão sendo produzidas/reproduzidas e das que permanecem na centralidade de São Paulo que pretendemos por meio das relações entre o mundial e o local e, entre o local e o entorno (intra-urbano), apontar a necessidade de se repensar a cidade, porque:

Na morfologia, encontramos as marcas daquilo que resiste e daquilo que traz a marca da transformação, marcas da mudança radical feitas pelas operações cirúrgicas impostas pelo planejamento funcionalista, que visa a realização da acumulação continuada, uma sincronia quebrada por rupturas que aparecem nas formas que revelam as estratégias as mais diversas dos agentes que produzem a cidade - voltadas a reprodução das frações do capital (CARLOS, 2004: 81)

$E$, assim, certos de que as morfologias que compõem a centralidade urbana carregam em si as marcas da atividade produtora, suas relações de produção, bem como as relações sociais é que pretendemos localizar os agentes que movimentam a transformação da cidade, que atuam nesta centralidade, para desvelar seu processo de produção e suas possíveis relações, ou não, com o Centro de São Paulo e os demais Centros mundiais.

Como a totalidade da centralidade São Paulo não seria possível de ser estudada nesta pesquisa, optamos por um estudo de caso a partir do centro Berrini que reproduz esse processo de produção e reprodução da centralidade urbana na cidade de São Paulo. O centro Berrini é considerado como uma área das mais recentes na centralidade de São Paulo, concentrando a maioria dos edifícios "inteligentes" e se apresenta como um local de afluxo de investimentos para escritórios de empresas transnacionais e assim nos aponta um dos principais 
agentes sobre este espaço que é o capital hegemônico mundial - que também atua em outras áreas da centralidade, como por exemplo, no Centro com as "parcerias" públicas - privadas no programa de "revitalização" do centro.

Por outro lado, existe o interesse do capital local que, associado ou não ao mundial, também realiza sua ação sobre toda a centralidade, notoriamente o setor imobiliário, em que localizamos um dos agentes hegemônicos.

Podemos considerar que tais ações mundiais e locais economicamente hegemônicas precisam do amparo legislativo e jurídico para se espacializar, então, localizamos outro agente que é o poder público - o Estado. Temos três grandes ações hegemônicas atuando sobre esta centralidade e interferindo diretamente sobre sua transformação.

Não podemos esquecer a existência de outras forças, ou agentes, os que vivem neste espaço, ainda que considerados não hegemônicos: moradores e trabalhadores, principalmente os das áreas precárias do entorno - a periferia imediata $^{8}$. Será que eles, ao fazerem parte, não agem e reagem, produzindo / reproduzindo parte desta espacialização da globalização que, ao ser transformada em ações concretas, cria uma nova morfologia, formas visíveis em sua arquitetura?

O período desta pesquisa será limitado a partir da década de 70 , momento de mudanças no modo de produção, onde a produção predominantemente fordista começa a compartilhar de um modelo flexível de produção. Este período coincide com os avanços técnicos que possibilitaram a globalização. Cabe saber, em que medida, estas mudanças interferiram na produção e reprodução social na centralidade de São Paulo.

Para respondermos a questão em pauta de analisar e entender como a espacialização da globalização está contribuindo na fragmentação ou na expansão e concentração da centralidade de São Paulo, iremos inicialmente, localizar, descrevendo o centro Berrini e o processo de formação da sua centralidade; em seguida faremos uma breve descrição da formação do Centro de

\footnotetext{
${ }^{8}$ Henri Lefebvre. O direito à cidade. Para se referir ao momento que segue a 1848 na França em que a burguesia está solidamente assentada sobre a cidade e cercada pela classe operária, enquanto os camponeses afluem, instalam-se ao redor das 'barreiras', das portas, na periferia imediata (2004:15)
} 
São Paulo, seu desdobramento e expansão da centralidade buscando focalizar, nesse processo, o surgimento e desenvolvimento da Berrini; no desenvolvimento apontamos e analisamos os agentes que produzem e reproduzem este centro, para entender como se dão, ou não, as relações com os demais centros mundiais e o Centro de São Paulo. Assim, pretendemos analisar e entender como a sociedade se reproduz reproduzindo o espaço no atual processo de globalização econômica.

Deste modo estruturamos nossa pesquisa da seguinte maneira:

No primeiro capítulo em - Berrini: A globalização da várzea - iniciamos contextualizando a região da Berrini nosso objeto de estudo para a compreensão de como se dá a espacialização da globalização no centro Berrini. Iremos neste capítulo localizar e descrever a região da Berrini realizando uma análise de seu processo de produção, de como aconteceram suas primeiras ocupações junto à várzea do Rio Pinheiros e do Córrego Águas Espraiadas chegando as atuais ocupações que dão origem a um conjunto que simboliza uma área de "modernidade", um centro global na centralidade da Cidade de São Paulo.

No segundo capítulo - Da Capela Jesuíta à Centralidade São Paulo realizamos um breve histórico da Cidade de São Paulo para descrever e analisar o processo que a originou desde a formação do Centro e seu desdobramento.

Demonstramos como o Centro se desdobrou e, posteriormente como a sua centralidade continua a se desdobrar a ponto de alcançar a periferia. Identificamos os agentes que produzem a Cidade e a espacialização da globalização econômica em sua centralidade. Acompanhamos o desdobramento da sua centralidade na expansão urbana para entender como a Berrini se insere neste contexto.

No terceiro capítulo - Os agentes hegemônicos - Procuramos demonstrar a relação de interdependência entre o local e o mundial na produção e reprodução social do espaço. Abordamos primeiro uma relação do local com o mundial via globalização enquanto um fenômeno concreto de expansão do capitalismo, assim, localizamos centros - pólos - dentro da cidade mundial que é São Paulo. 
Expomos que a globalização necessita para acontecer de ancoragens espaciais criando, no espaço mundial, centros que são, nesse caso, lugares reproduzidos com a intenção de responder à reprodução do capital - daí essa busca em se tentar homogeneizar os lugares, dotando-os de um aspecto, uma morfologia (materialidade) no espaço que a distingue dos demais.

Desvelamos como se deu o processo político engendrado pelo capital para se espacializar e como politicamente se espacializa a necessidade de espaços de "modernidade" e, se o centro Berrini fragmenta a centralidade de São Paulo ou a reforça requerendo a "revitalização" do Centro.

No quarto capítulo - Os agentes não hegemônicos - pesquisamos uma periferia imediata ao centro Berrini que é a favela da Mandioca. Por meio da sua localização no plano diretor da cidade e de entrevistas com seus moradores, expomos e analisamos como as pessoas e trabalhadores desta região participam desse processo urbano que desponta, também, como parte da espacialização da globalização na centralidade de São Paulo.

Apontamos que mesmo na resistência ao processo de produção que faz desdobrar a centralidade sobre a periferia, os moradores que fazem parte do chamamos agentes não hegemônicos da favela da Mandioca fazem uso de expedientes do mesmo modelo produtivo dos agentes hegemônicos. É o caso da especulação imobiliária no interior da favela que está sendo possível devido ao adensamento da favela com a construção de casas de alvenaria e, também, das construções de garagens junto ao Conjunto Cingapura que são do ponto de vista legal, irregulares, para obter a renda do aluguel. Após isso, tecemos as considerações finais. 


\section{A Berrini: A globalização da várzea.}

"Começo a conhecer-me. Não existo.

Sou o intervalo entre o que desejo ser e os outros me fizeram..." Fernando Pessoa (1985:117)

A região sudoeste da Cidade de São Paulo junto à Marginal do Rio Pinheiros, entre os Viadutos Engenheiro Ary Torres/Bandeirantes e Caio Pompeu de Toledo/Morumbi (ver mapas 3 e 4), apresenta uma paisagem que impressiona quem a olha a partir da Marginal, foto $n^{\circ} 1$.

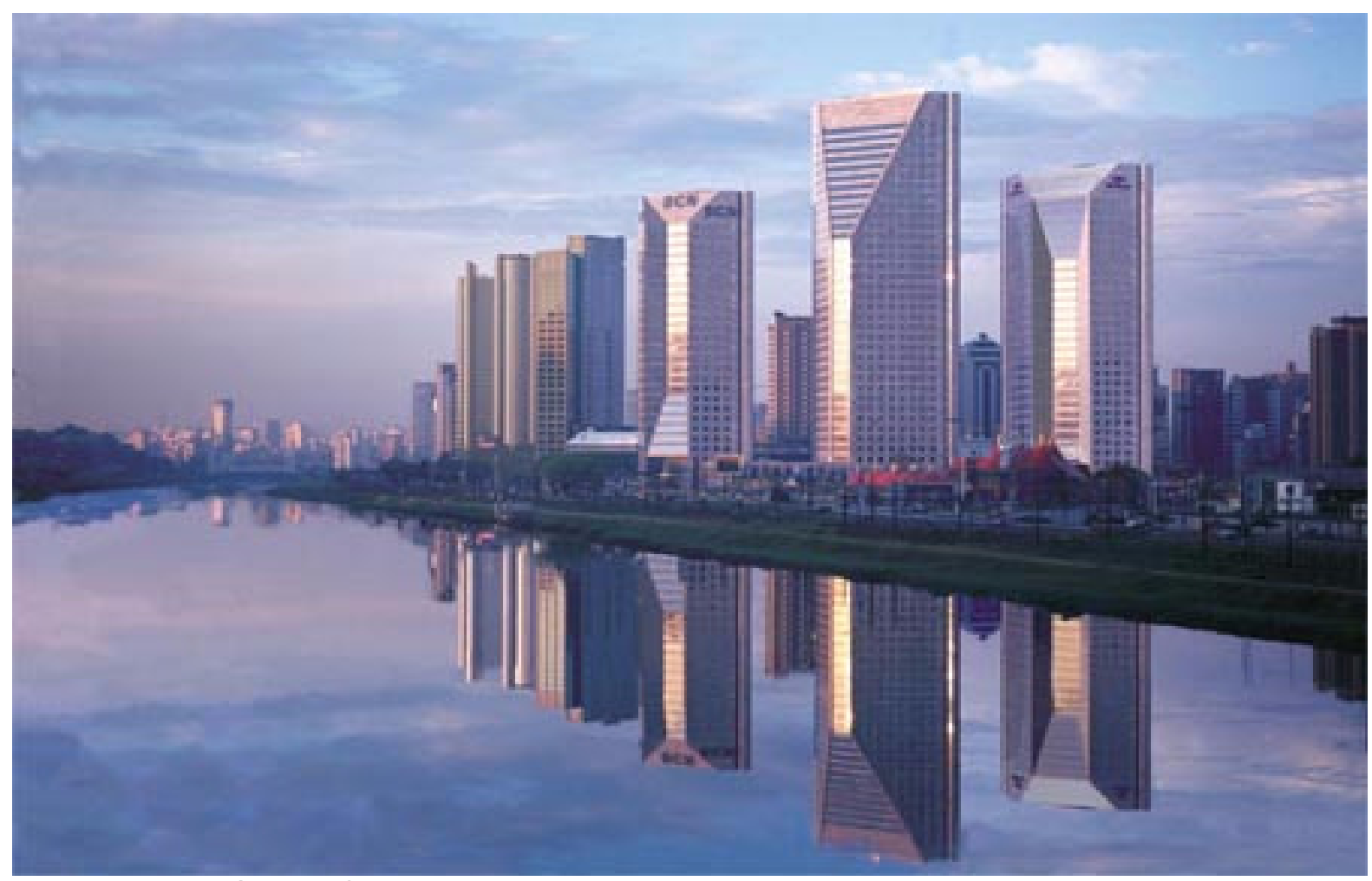

fonte: Bolsa de Imóveis de São Paulo in www.bolsadeimoveis.com.br

Um conjunto imponente de edifícios espelhados que, ao mesmo tempo em que refletem o sol, a água, o céu, os carros, as pessoas etc., é refletido nas águas escuras e poluídas do Rio Pinheiros. É uma paisagem que encanta, reflete ou ilude? O que temos à nossa vista é mais uma das centralidades de São Paulo - é o centro Berrini. Uma visão tão fantástica que chega a ser confundida com a literatura de Calvino quando escreve que: 
Mapa 3.

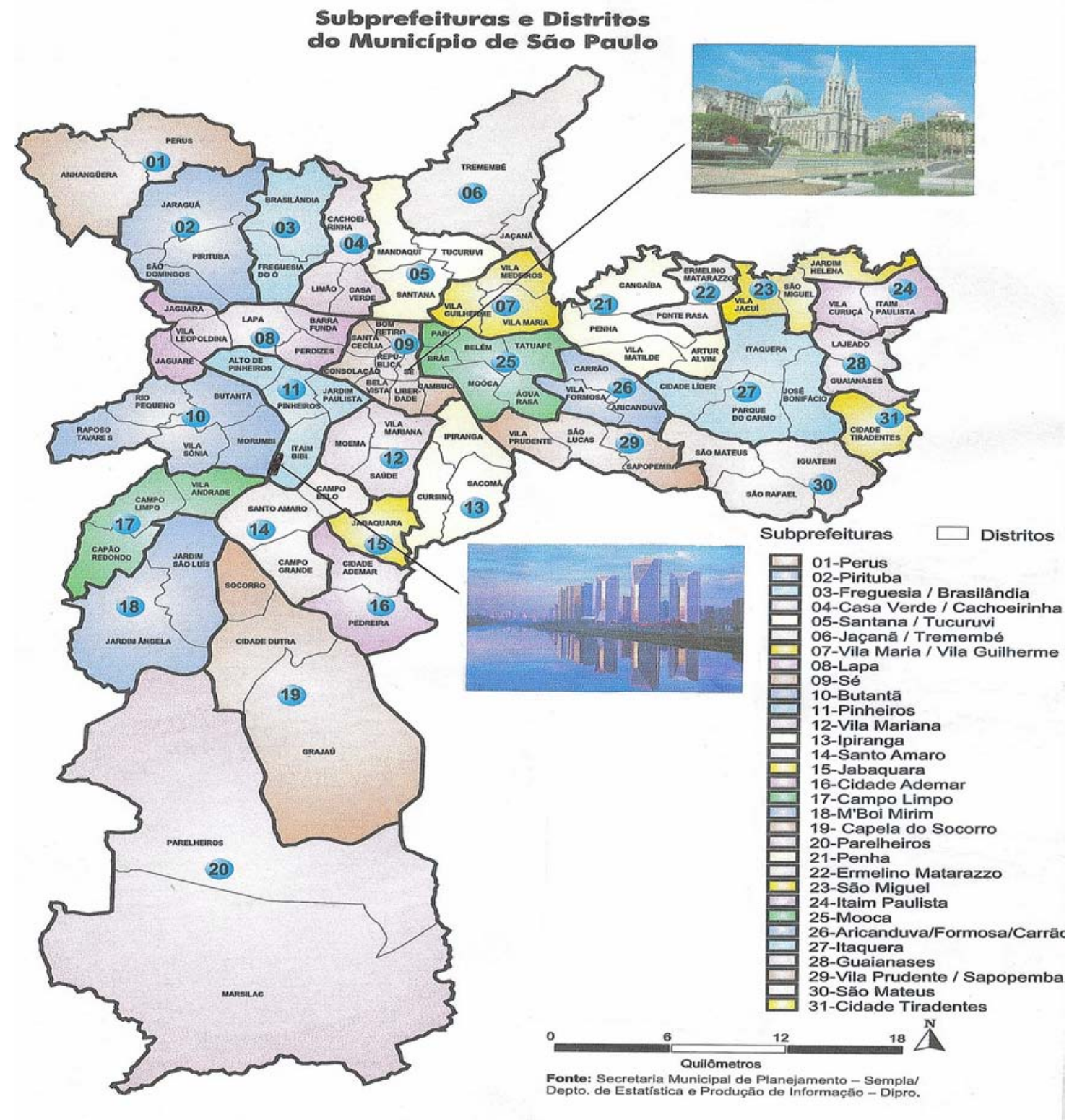


Mapa 4.

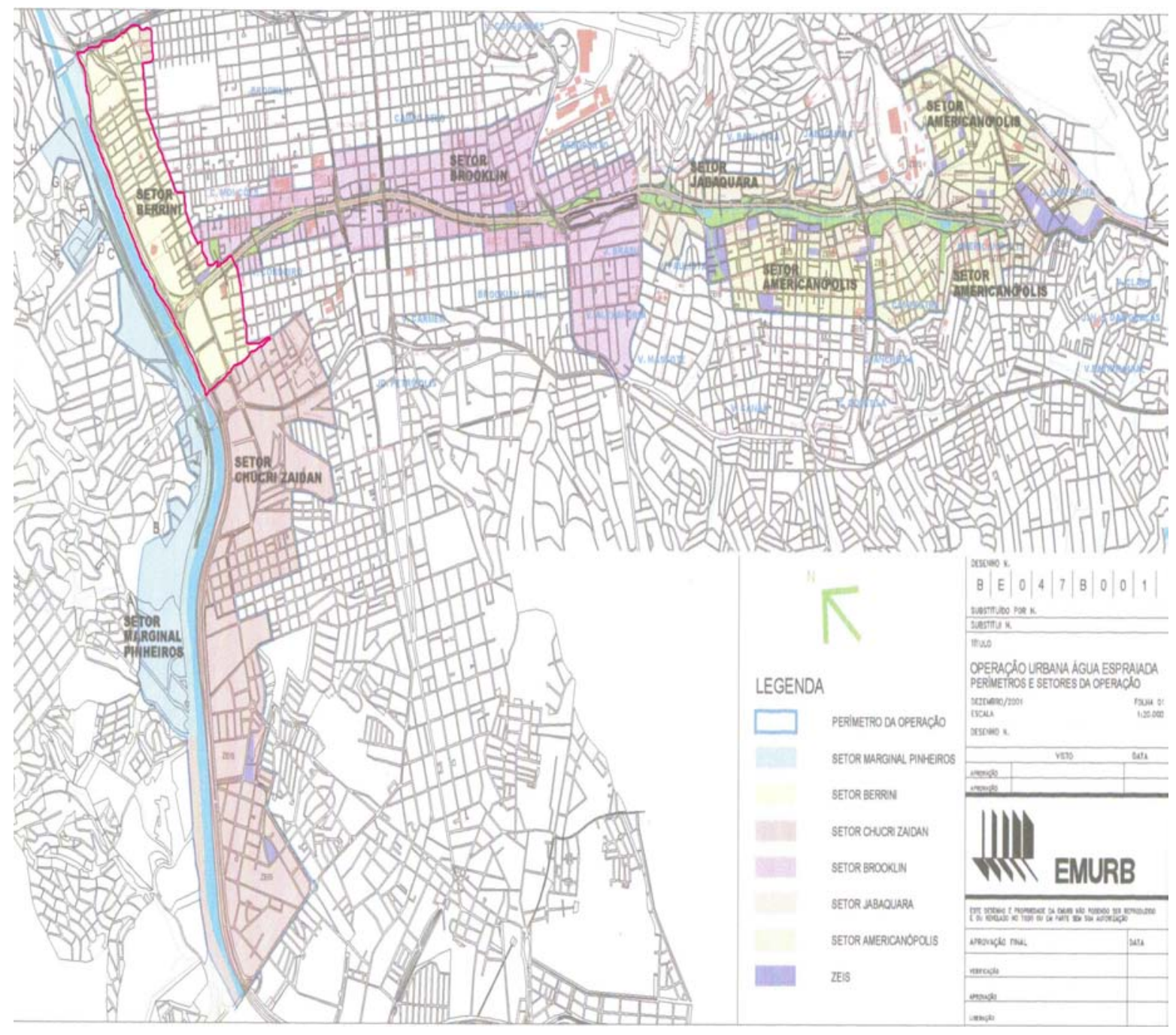


Os antigos construíram Valdrada à beira do lago com casas de varandas sobrepostas e com ruas suspensas sobre a água desembocando em parapeitos balaustrados. Deste modo, o viajante ao chegar depara-se com duas cidades: uma perpendicular sobre o lago e a outra refletida de cabeça para baixo... (2003:53)

O que podemos perceber entre o real e a fiç̧ão é o fato de que as duas paisagens apresentam características que aproximam a Berrini de Valdrada e nos são particularmente interessantes para a pesquisa: a primeira é a de que ambas são construções sociais, lembrando que todas as cidades o são e Valdrada, nos informa Calvino, remete à sociedade dos antepassados, foram os antigos que a construíram. Falta saber quem construiu a Berrini. A segunda semelhança é tratarem-se de duas paisagens que estão refletidas, onde Valdrada é refletida de modo invertido, como sabemos. E a Berrini é refletida de que modo, ou é reflexo de quê, se não é ficção? Lefebvre nos lembra que há um:

... jogo de espelhos: plenitudes e decepções (...) As ondas do visual e da claridade quebram sobre o que se sente e se toca (...) O espaço sensorial-visual não constitui senão uma camada/inscrição, um sedimento que persiste na sedimentação, na compenetração dos espaços sociais (...) nos produtos, objeto ou espaço, apaga-se tanto quanto possível os traços da atividade produtora (1974: 178 e 179)

Instigados para avançar e ir além do espelho e do seu reflexo, buscaremos restituir os traços da atividade produtora do espaço no centro Berrini. Iniciamos esse caminho descrevendo que a região da Berrini apresenta, atualmente, aproximadamente cem edifícios comerciais, centralizando boa parte das atividades do setor terciário moderno, sendo que alguns se destacam como o World Trade Center, o Hotel Meliá, o Hilton, o Shopping D e D, as instalações da Rede Globo, a sede do Bank Boston, o Hotel Hyatt entre outros e, como já vinha sendo anunciado:

... a região em torno da avenida Luís Carlos Berrini se mantém como área propícia ao estabelecimento de novos prédios de escritórios, apresentando curva ascendente de crescimento desde a década de 1980 em função da quantidade de área passível de ser incorporada e que foi 
aumentada em 1997, com a abertura da avenida Águas Espraiadas... (CARLOS, 2001:145).

A tendência apontada acima da concentração de prédios de escritórios e valorização da região está sendo realizada com a concretização da avenida Água Espraiada ${ }^{9}$ (renomeada como avenida Jornalista Roberto Marinho) e a construção das alças de acesso à marginal Pinheiros que, "segundo especialistas, a expectativa de melhorias devido à operação urbana Água Espraiada já resultou em valorização real média de cerca de 10\% no valor dos terrenos" (Folha São Paulo, 30/10/2004).

Com a valorização crescente da região estão sendo criadas oportunidades imobiliárias, foto $\mathrm{n}^{\circ} 2$, para o segmento de moradias que atendam aos interesses do mercado e dos trabalhadores de alto nível que atuam neste centro, "... depois de uma década de supremacia dos imponentes prédios comerciais, a região da Avenida Engenheiro Luís Carlos Berrini, no Brooklin, zona sul, inicia um novo processo de transformação. Desta vez, para virar também reduto de modernos edifícios residenciais."( Estado de São Paulo,12/10/2005)

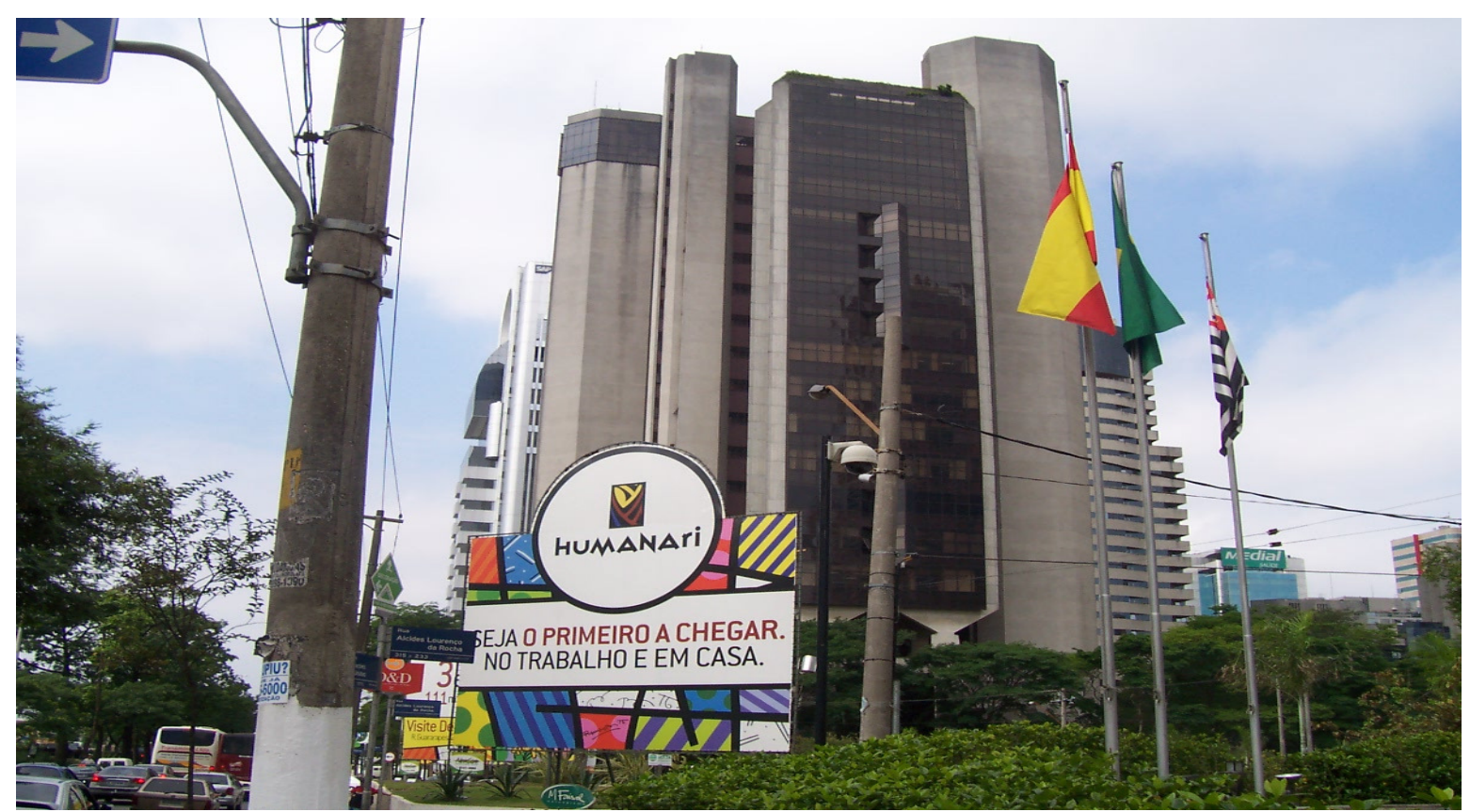

Foto do autor 2. outubro 2005 - Avenida Nações Unidas - oferta de imóveis residenciais

\footnotetext{
${ }^{9}$ A grafia do nome Água Espraiada embora seja utilizada em algumas citações no plural, em todos os documentos oficiais (Diário Oficial e site da PMSP) é utilizada no singular, grafia que passamos a utilizar tanto para a Avenida, o Córrego e a Operação Urbana.
} 
Mas, como podemos observar na foto $n^{\circ} 3$, a região do centro Berrini possui em seu entorno, uma periferia imediata, formada por alguns pólos: a favela que acompanha a atual Avenida Jornalista Roberto Marinho que, preferimos continuar a denominar de Água Espraiada, já que boa parte da favela atual, Jardim Edith II, é resultado do espraiamento da antiga favela do Jardim Edith removida por um consórcio de empresas da Berrini (FIX, 2001) e, foto $n^{\circ} 4$, também a favela da Mandioca, no Real Parque Morumbi, localizada no lado oposto da Marginal Pinheiros e parcialmente encoberta pelo supermercado Pão de Açúcar, A Leroy Merlin, o equipamento público-privado do Projeto Casulo e a EMEI Pero Neto e o conjunto de apartamentos do Projeto Cingapura.

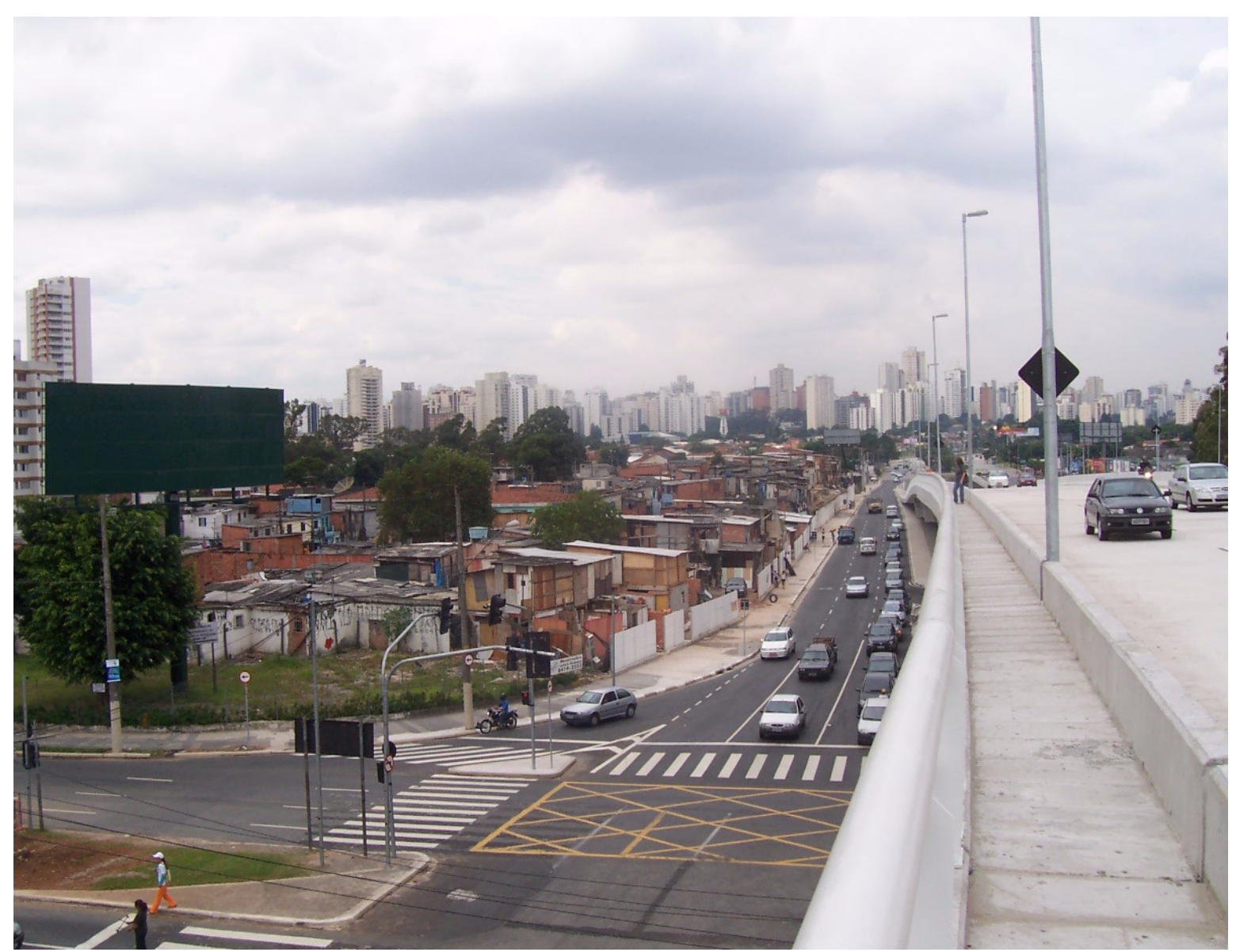

foto do autor 3. Cruzamento da Água Espraiada com a Avenida Engenheiro Luís Carlos Berrini /abril 2006 


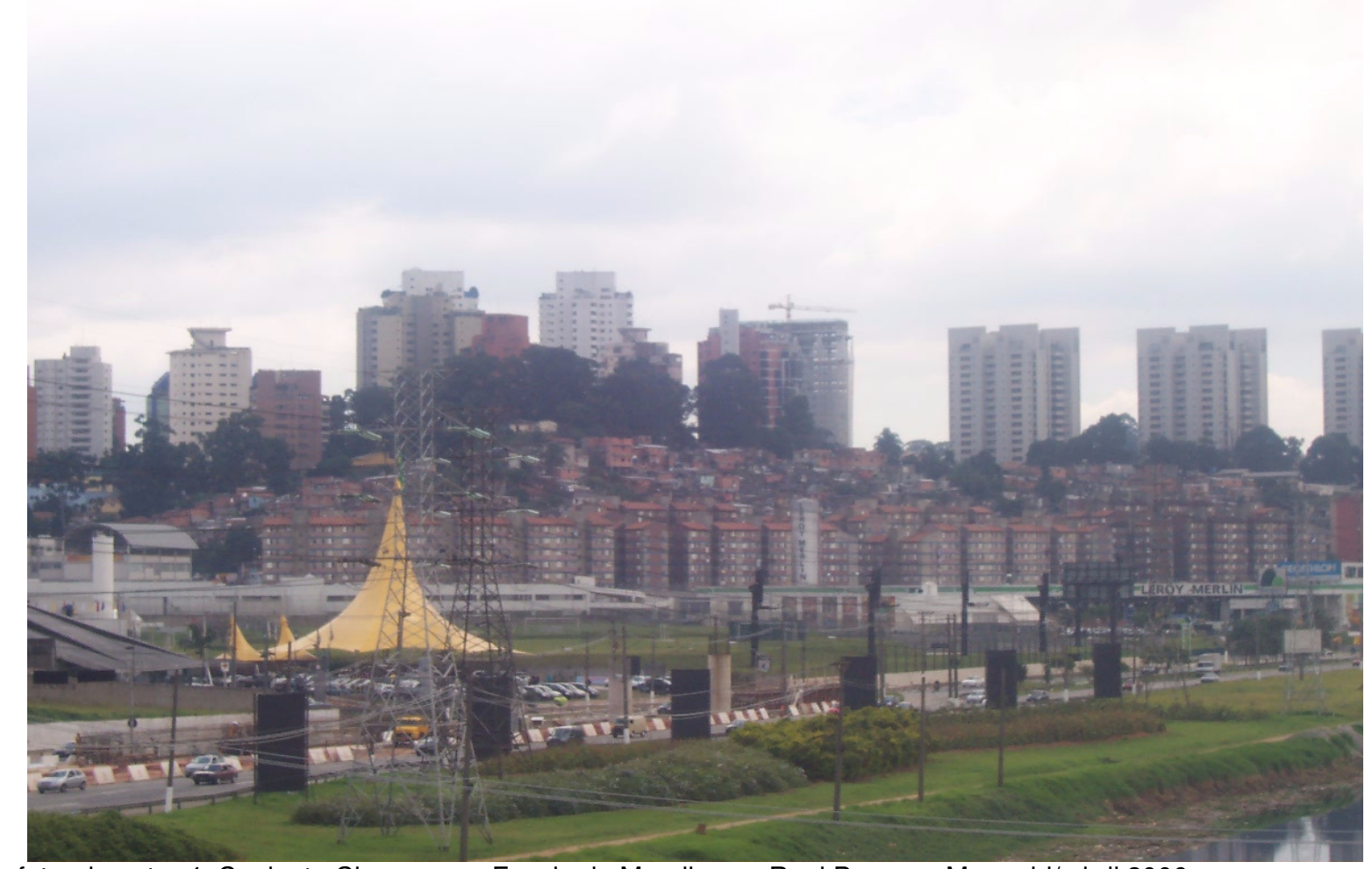

foto do autor 4. Conjunto Cingapura e Favela da Mandioca - Real Parque - Morumbi/ abril 2006

Nesta primeira descrição do centro Berrini e de suas periferias imediatas, destaca-se na paisagem a contradição do espaço social: um pólo "moderno" e rico junto aos pólos "simples" e pobres. Esta aproximação por meio da localização começa a desvelar que o espaço produzido comporta as diferentes classes sociais e as relações de poder entre elas, sendo que para BOURDIEU:

A estrutura do espaço social se manifesta, assim, nos contextos mais diversos, sob a forma de oposições espaciais, o espaço habitado (ou apropriado) funcionando como uma espécie de simbolização espontânea do espaço social. Não há espaço, em uma sociedade hierarquizada, que não seja hierarquizado e que não exprima as hierarquias e as distâncias sociais, sob uma forma (mais ou menos) deformada e, sobretudo, dissimulada pelo efeito de naturalização que a inscrição durável das realidades sociais no mundo acarreta: diferenças produzidas pela lógica histórica podem, assim, parecer surgidas da natureza das coisas... (1999: 160). 
O espaço habitado (ou apropriado) na região da Berrini pode tanto atuar "naturalizando" ações e reorganizações das relações sociais através dos espaços (espaços para ricos, classe-média, pobres, sem-nada), dando a impressão de que essas diferenças sempre existiram, porque estão colocadas lado a lado no mesmo espaço; como, por outro lado, podem denunciar as desigualdades e injustiças sociais, desvelando o processo histórico que as produziram (condomínios de alto padrão cercados por favelas) que demonstram as relações desiguais e de exploração entre as pessoas em seu cotidiano, como podemos observar na foto $n^{\circ} 5$.

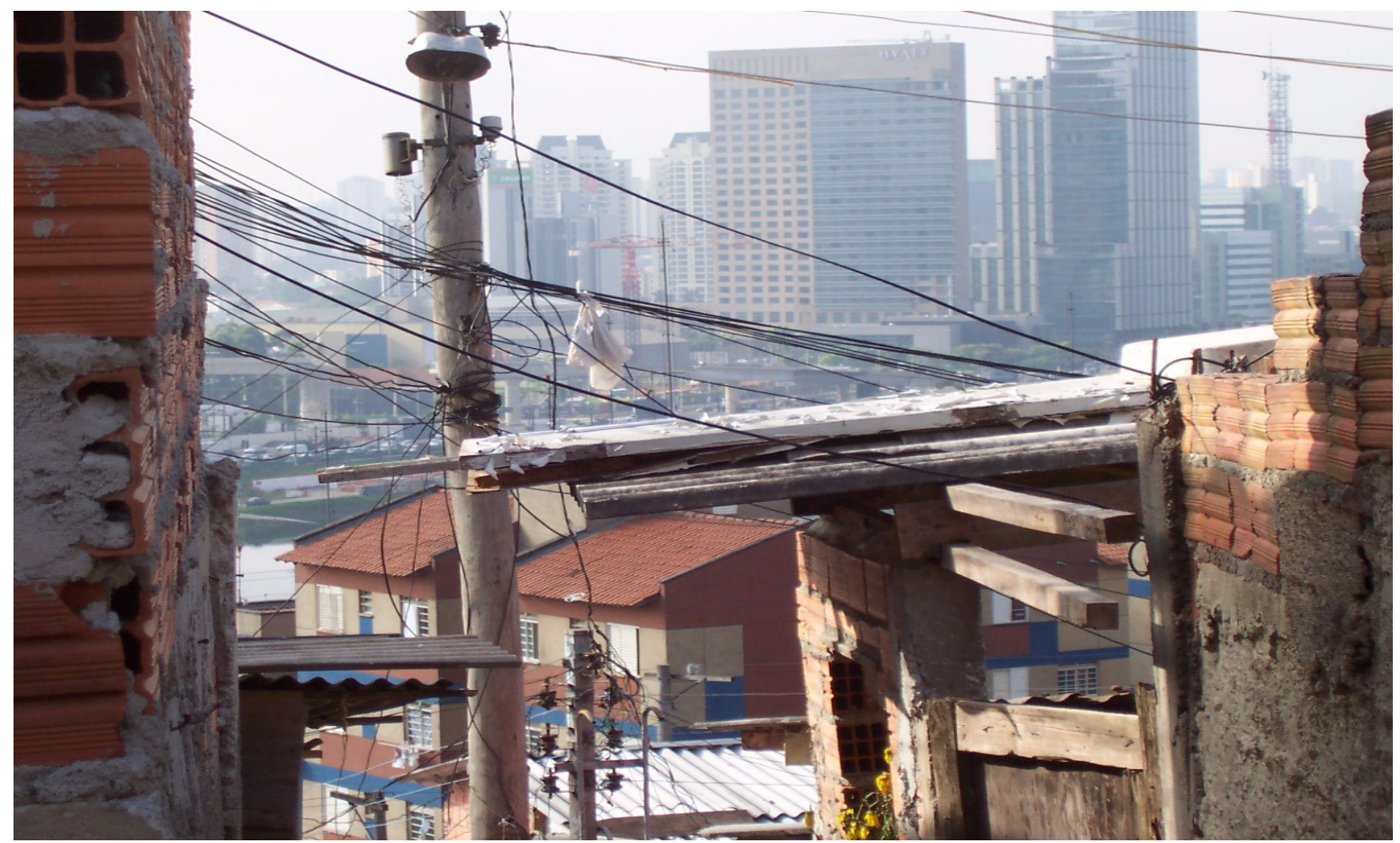

Foto 5. Vista do interior da favela da Mandioca - foto do autor/ fevereiro 2006.

Esses contrastes, a riqueza e a pobreza, o moderno e o arcaico, fazem parte de um processo maior de desenvolvimento urbano da metrópole ou é particularidade da Berrini? A Berrini representa a espacialização da globalização econômica? Da mesma forma, este "novo centro" Berrini reproduz o movimento de produção da centralidade de São Paulo ou trata-se de um centro vinculado a outros centros internacionais?

Para nos orientarmos nessa centralidade tão complexa e refazer o caminho da atividade produtiva que o engendrou, passamos a utilizar como referência 
espacial para entender a produção do espaço no centro Berrini - o córrego e a avenida Água Espraiada - que têm sido um dos elementos que permanecem mediante as reorganizações espaciais da região, sofrendo intensamente tanto ações públicas quanto privadas desde a origem da avenida Luís Carlos Berrini.

Uma das ações públicas específicas em relação ao córrego Água Espraiada ocorreu em 1964, quando o prefeito Prestes Maia (1961-1964), promulgou:

uma lei de melhoramento urbano que definia uma faixa de desapropriação ao longo do córrego Água Espraiada, destinada à construção de uma avenida com 60 metros de largura e 7 mil metros de extensão, iniciando-se na Marginal Pinheiros e finalizando no Bairro Jabaquara, na avenida Conceição.

No início dos anos 70 , o projeto foi reformulado pelo DER (Departamento Estadual de Estradas de Rodagem), para que essa "avenida de fundo de vale" fizesse parte do minianel viário metropolitano. Seria construída uma via expressa ligando a Marginal à Rodovia dos Imigrantes. As desapropriações para a execução dessas propostas foram iniciadas, mas a Câmara Metropolitana de Transportes modificou as diretrizes, transferindo o traçado do Anel Viário para a avenida Roque Petroni. A grande faixa desapropriada ao longo do córrego foi sendo progressivamente invadida, com a ocupação dos imóveis vazios e a construção de barracos e a formação de inúmeras favelas.

A região ao redor da Berrini era naquele momento ocupada basicamente por residências, e quase $60 \%$ do solo estava vazio (FIX, 2001:87)

Como surgiram os imóveis na região de várzea? Os barracos e a favela surgiram na área de risco, junto à várzea do córrego e do rio Pinheiros, mas e os imóveis vazios?

Conforme a foto $n^{\circ} 6$, podemos perceber que mesmo com a enchente ao longo das margens do rio Pinheiros, havia várias casas e, que certamente, eram pré-existentes à enchente de 1929 e "tudo indica que foi uma inundação e não uma enchente" (SEABRA, 1987:191). 


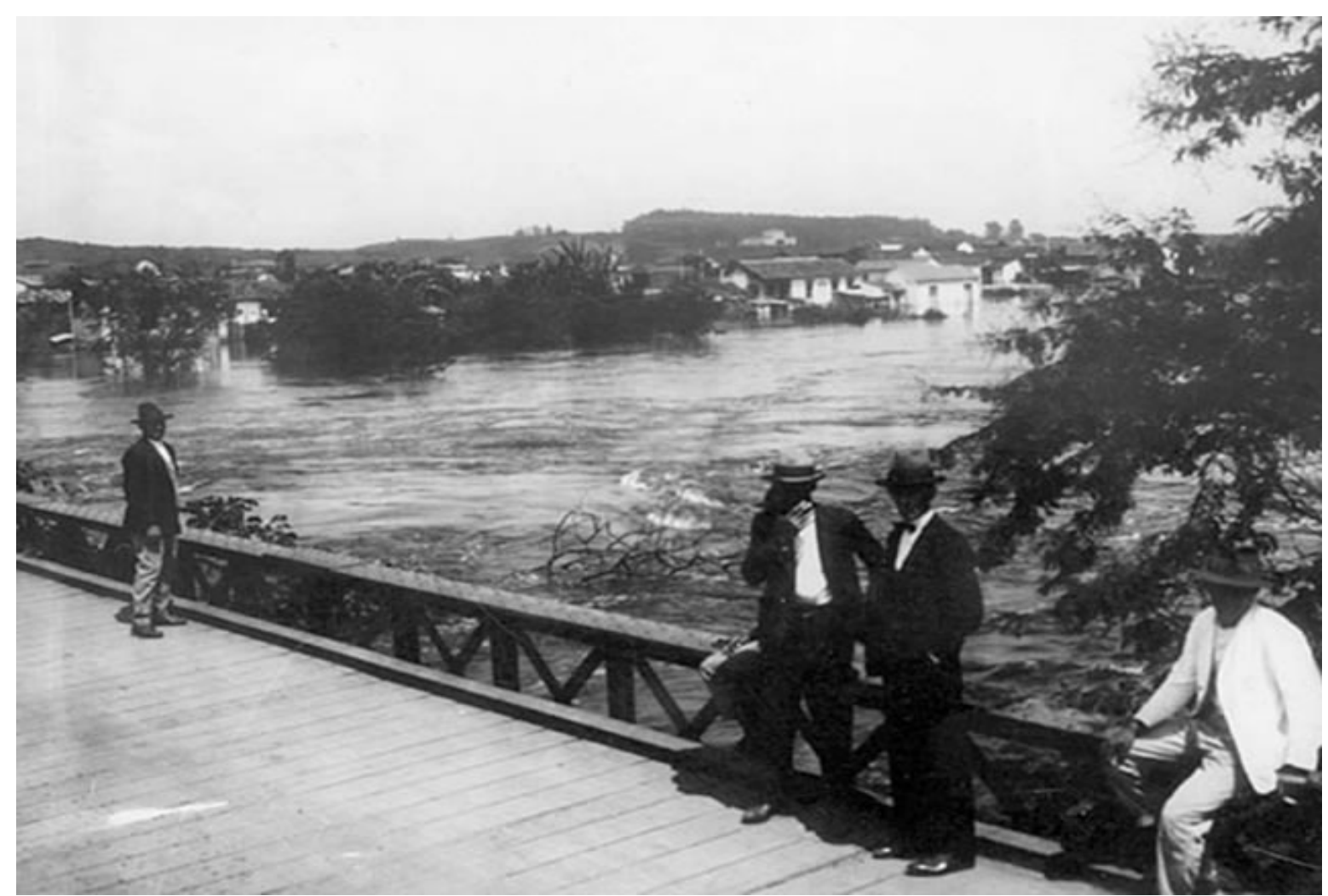

foto 6. fonte: Sempla - Hist. Demográfico Município de São Paulo. Enchente 1929, antiga Ponte de Pinheiros.

A Companhia Light teria contribuído para potencializar a enchente, no caso inundação, com o interesse de se apropriar de uma parcela maior dos terrenos junto à várzea do rio Pinheiros, na medida em que, a enchente foi de tal magnitude que ultrapassou o que geralmente ocorria na região e:

Essa parece ser a questão fundamental; garantir-se de uma superfície do terreno nas várzeas tão ampla quanto possível, sobre a qual exerceria os direitos contidos na Concessão que obtivera (SEABRA, 1987:191)

A Concessão (Decreto 4487 de novembro de 1928) se referia a todos os terrenos localizados abaixo da "linha de enchente" e, assim, a inundação possibilitou que os imóveis fossem "esvaziados" (no sentido de que seus ocupantes foram praticamente expulsos), com a ocupação da várzea do rio Pinheiros em um movimento de reprodução do capital que foi conduzido pelo 
Grupo Light $^{10}$ que controlou todo o processo de desapropriação dessa área, sendo que ao:

longo do rio Pinheiros, existiam áreas de loteamentos, que formavam pequenos bairros e que estavam inseridos abaixo da "linha da enchente", como era o caso de partes de Vila Leopoldina, de Pinheiros, do Itaim, de Vila Olímpia, de Vila Funchal, de Santo Amaro, de Capela do Socorro (...) Existiam também terras do poder público; as propriedades da prefeitura do Município de São Paulo, as do Instituto Butantã, além das terras do velho leito do Pinheiros que, em princípio, também eram públicas (...) A Companhia enfrentou esses proprietários de diferentes formas. O seu objetivo, cabe reiterar, era de tornar-se proprietária para apropriar-se dos benefícios ou do valor dos melhoramentos que realizaria nas terras delimitadas. (SEABRA, 1987:202)

Esta prática de antecipação do valor do solo pelo Grupo Light, não considerou, em momento algum, a existência de famílias que viviam nas várzeas do rio Pinheiros, que foram desalojadas e despejadas, deixando para trás os imóveis vazios. No entanto, necessitamos apontar que:

a Companhia Light no vale era a modernidade que se impôs com uma força avassaladora fundada numa racionalidade muito objetiva garantida de um lado, pelo domínio de conhecimentos técnicos e científicos de outro, pela lógica que preside o processo de produção de mercadorias (...) Ao ganhar condição legal para produzir o canal, tinha consciência plena de que estaria produzindo um espaço da cidade. Por isso mesmo foi expropriando e apropriando-se das terras das várzeas... (SEABRA, 1987: 244)

A consciência da produção de um espaço da cidade e de tornar esse espaço uma vantagem comparativa, fazendo uso da idéia de "modernidade" associada à de "progresso", permitiu escamotear os objetivos de ampliação das possibilidades de reprodução do capital e que induziu as intervenções nesta região. Sendo que uma delas foi a criação da avenida Luís Carlos Berrini quando:

Para inverter o curso do rio, a Light implantou em 1940 a Usina Elevatória de Traição(...) Essa unidade de

\footnotetext{
${ }^{10}$ Para saber mais sobre a ocupação das margens dos rios Tietê e Pinheiros ver Odette Seabra. Os meandros dos rios nos meandros do poder. Tietê e Pinheiros: valorização dos rios e das várzeas na cidade de São Paulo, tese de doutorado, FFLCH-USP, São Paulo, 1987.
} 
bombeamento reversível elevava o nível do rio no trecho em que desaguavam três córregos: Cordeiro, Água Espraiada e Traição. Por isso foi necessária a construção de um dreno que recebesse as águas dos córregos e lançasse-as no Pinheiros, no trecho além da Usina de Traição: o Dreno do Brooklin, implantado nos anos 70. Nas margens do dreno, foram abertas as pistas de uma avenida, posteriormente denominada Luís Carlos Berrini. (FIX, 2001: 85)

Contudo, é no final dos anos 70 que uma nova dinâmica urbana passa a acontecer na região da Berrini, com dois acontecimentos importantes: a desapropriação dos imóveis junto ao córrego Água Espraiada pelo DER, que ficaram abandonados, "desvalorizando" a região, e logo após a inauguração do Centro Empresarial São Paulo em 1977, indicando um novo pólo de expansão.

Esse processo de produção da cidade cria a possibilidade de reprodução do capital que irá sendo retomado constantemente nesta região, promovendo desde a tentativa de remoção da favela do Jardim Edith, que veremos adiante, como a tentativa de criar um centro atrelado à idéia de modernidade e também um marco no espaço da cidade com a construção do Complexo Viário Real Parque e sua enorme Ponte Estaiada.

No intervalo, entre o abandono e o início de revalorização da região e aproveitando as possibilidades da localização e dos preços baixos dos terrenos e casas junto às áreas de várzea na região da Berrini, é que começam a serem construídos os edifícios de escritórios da Bratke Collet que atendiam a uma nova demanda empresarial com os edifícios de até oito pavimentos, projetados para se adequarem às necessidades das grandes empresas. Lajes de planta livre de 500 metros quadrados, equipamento de serviço em bloco próprio destacado e sistema de ar-condicionado central começam a despontar na paisagem, como podemos ver na foto $\mathrm{n}^{\circ} 7$. 

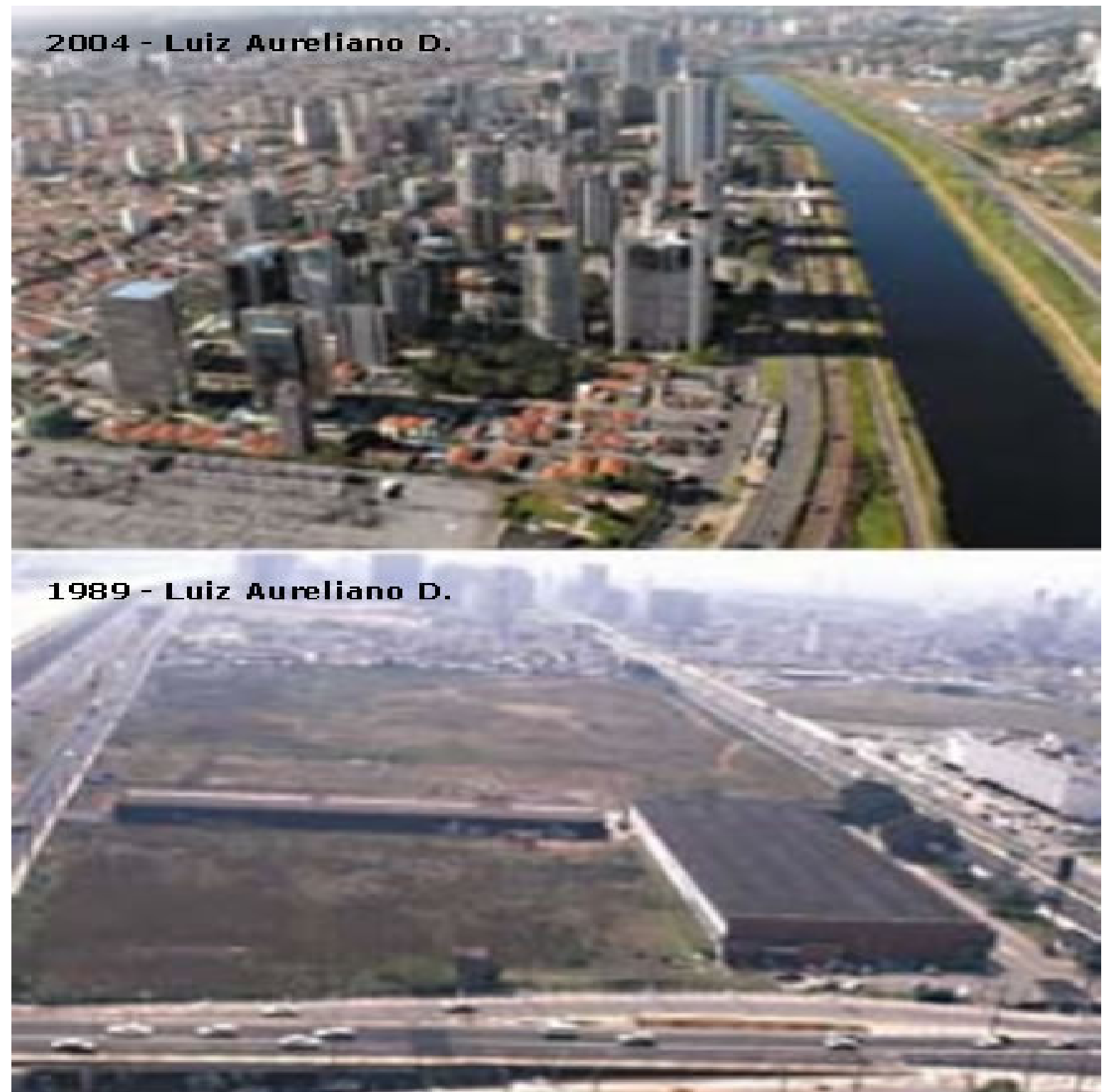

foto 7. fonte: Sempla - Hist. Demográfico Município de São Paulo.

Com o tempo a região foi atraindo cada vez mais estabelecimentos do setor terciário, escritórios de indústrias, comércio e prestação de serviços. A centralidade Berrini foi potencializada com a Operação Urbana Faria Lima:

Criava-se, assim, nova articulação no sistema viário, ligando, de forma imediata, a área da avenida Luís Carlos Berrini aos bairros dos Jardins (Paulista, América) e à avenida Brigadeiro Faria Lima (leito da antiga avenida). Isso melhorou sensivelmente o acesso a ambas as áreas, que antes se fazia por meio de ruas estreitas e tortuosas dos bairros de Vila Olímpia e Itaim, bairros que "estavam no meio do caminho" entre dois pólos econômicos importantes: região da 
avenida Faria Lima, de um lado, e a região da avenida Luís Carlos Berrini, de outro - ambas voltadas para a atividade bancária e de serviços. Por sua vez, a Nova Faria Lima também se articularia, por meio da avenida Juscelino Kubitschek, com a saída do túnel construído sob o leito do rio Pinheiros, que ao sul liga a outra margem do rio Pinheiros aos bairros do Morumbi; ao norte a ligação se faz pela avenida Uberaba até a avenida República do Líbano e com o novo complexo de túneis Ayrton Senna, que permitiria a ligação com o Ibirapuera e Vila Mariana e o aeroporto de Congonhas. Com isso se desenharia o corredor viário sudoeste-centro (CARLOS, 2001, 64 e 65)

A utilização das operações urbanas como instrumentos de interesses particulares, mas fazendo uso do poder público (leis, investimentos e uso do solo), ainda que as estratégias sejam diferentes, demonstra uma aproximação entre a ação realizada pela Companhia Light nos anos 20/30 e as ações que grupos de empresários e o poder público estão realizando atualmente, na mesma região, com as parcerias " público - privadas".

O interesse em reproduzir o capital com o uso e ocupação do solo reproduz a mesma lógica utilizada em vários momentos na região da Berrini, mudando apenas alguns agentes, mas sempre contando com o auxílio do poder público, é o que podemos constatar com o trecho do depoimento de Roberto Bratke concedida a Frúgoli:

Veja, eu e o Unibanco, a Bolsa de Imóveis e o World Trade Center fizemos um trabalho junto à prefeitura, levantamos dinheiro de todos os proprietários de andares para tirar toda a favela (...) Nós conseguimos convencer, vamos dizer, quase todos os investidores daqui, que eles iam pagando um determinado valor, e eles teriam um benefício de valorização sem a favela (...) E houve uma valorização imobiliária? Como é que vocês avaliam isso? Eu acho que isso viabilizou muita coisa, a Globo comprou um terreno lá porque não tinha mais favela... (FRÚGOLI, 2000: 206/207). ${ }^{11}$

De fato, viabilizou muita coisa, permitiu a criação de uma vantagem comparativa na região com a remoção da favela, valorizando o preço dos terrenos

\footnotetext{
${ }^{11}$ Em Parceiros da Exclusão. São Paulo: Boitempo, 2001. Mariana Fix faz o acompanhamento de toda a remoção da favela do Jardim Edith.
} 
e imóveis, ao mesmo tempo impondo uma imagem de poder com um simbólico conjunto de edifícios do "World Trade Center", ao lado de um outro símbolo que é a "rede Globo de Televisão" uma liderança na audiência televisiva e, portanto, formadora de opinião que reforça a imagem de inovação e modernidade na região.

No entanto, a lógica permanece a mesma, o alicerce para a mudança na paisagem e incorporação de valor ao solo, se deu por meio da retirada da favela que, ocupava parte de um espaço público sob domínio do DER, como vimos anteriormente, na desapropriação dos imóveis junto ao córrego Água Espraiada nos anos 70 e o valor social do uso do solo se esvai...

Mesmo com todo o esforço dos empresários em "parceria" com o poder público, boa parte dos moradores do que se denominava favela do Jardim Edith acabaram por resistir e permaneceram na região junto a avenida Água Espraiada (atual Av. Jornalista Roberto Marinho) e a rua Charles Coulomb, dando origem ao que se denomina hoje favela do Jardim Edith II, ou seja, parte da favela se espraiou junto a avenida, surgindo a favela do Jardim Edith II, conforme foto $\mathrm{n}^{\circ} 2$ e, isso, deve-se a razão de que também para os moradores da favela permanecer nesta região é uma vantagem comparativa, não se gasta com transporte, existem escolas e postos de saúde próximos, a oferta de empregos é maior etc.

Atualmente, com a construção dos viadutos de acesso entre a marginal direita do rio Pinheiros "Viadutos José Bonifácio Coutinho Nogueira" à Avenida Jornalista Roberto Marinho no Brooklin, reorganiza-se novamente o espaço da região e, novamente, no caminho temos a favela que precisa, nessa lógica que se tornou "comum" na região, ser removida e, assim:

os barracos do Jardim Edith, mais conhecida como Favela do Buraco Quente, vão ser retirados pela Prefeitura. Hoje eles ocupam uma das calçadas e as margens da avenida Jornalista Roberto Marinho, perto do cruzamento com a Luís Carlos Berrini... (OESP 19/08/2005)

Os moradores da favela, conforme foto $\mathrm{n}^{\circ} 8$, insistem em permanecer no local e pedem que seja realizada a reurbanização da favela e não a sua remoção. 


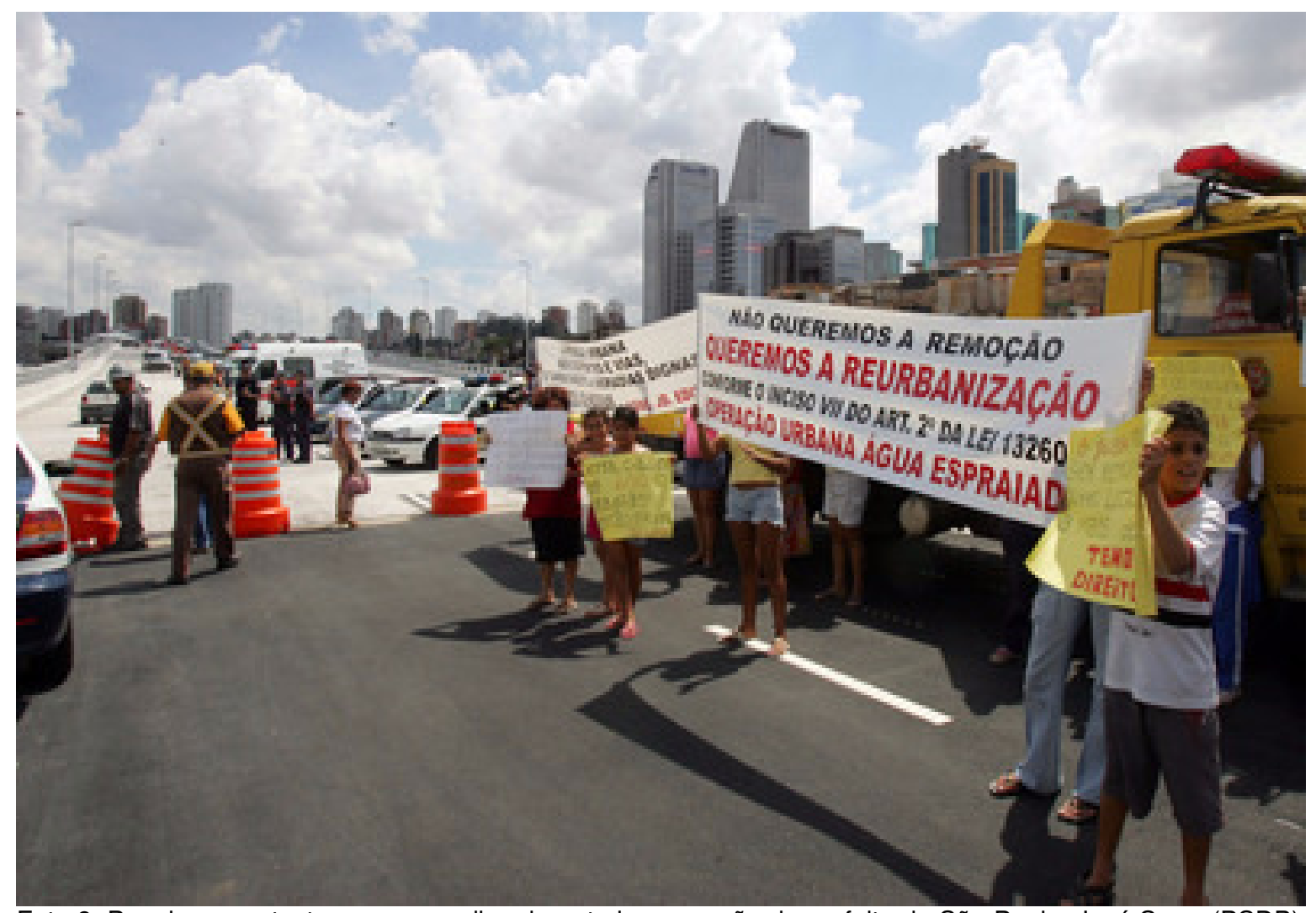

Foto 8. Populares protestam por moradias durante inauguração do prefeito de São Paulo, José Serra (PSDB), do viaduto de acesso da Avenida Jornalista Roberto Marinho, zona sul da cidade, nesta sexta. 24/03/2006 Foto: JOSÉ PATRÍCIO/AGÊNCIA ESTADO/AE

Existe ainda um projeto, que já vem sendo encaminhado na articulação público - privada, intenção de potencializar a Centralidade Berrini, não apenas no contexto nacional, mas principalmente como centralidade mundial, que necessita se afirmar por símbolos, conforme o discurso oficial que diz:

Pouco se percebe que a cidade de São Paulo, embora seja uma das maiores cidades do mundo, não possui um marco arquitetônico que a simbolize internacionalmente, como em Paris (Torre Eiffel), Nova York (Estátua da Liberdade) ou Rio de Janeiro (Cristo Redentor).

Os viadutos que ora são entregues à população são o primeiro passo em direção ao preenchimento dessa lacuna: a ponte que está sendo erguida, ligando as duas margens do Rio Pinheiros será, com certeza, um símbolo de nossa cidade, a ponte terá um mastro de 140 metros de altura, praticamente o mesmo tamanho do atual símbolo da cidade, o Edifício Banespa, no centro da cidade (D.O.C. 25/03/2006) 
Podemos constatar que existe no processo de transformação urbana da centralidade de São Paulo uma correspondência direta entre os interesses políticos associados aos interesses econômicos que se realizam concretamente com a produção da infra-estrutura que privilegia a poucos. Este processo combinado e desigual de produção urbana em São Paulo fica evidenciado, no caso da Berrini, descrito acima, mas também acontece no Centro onde, FRÚGOLI, 2000 , em seus anexos ao analisar a foto $n^{\circ} 9$ diz:

a Estação e Praça Júlio Prestes em 1997 e em 2000 - hoje abrigando uma sala de concertos e a sede da Orquestra Sinfônica do Estado de São Paulo. Uma área popular marcada pela 'cracolândia' e pelo comércio informal, que vem sendo aos poucos destinada ao consumo cultural das classes média e alta.
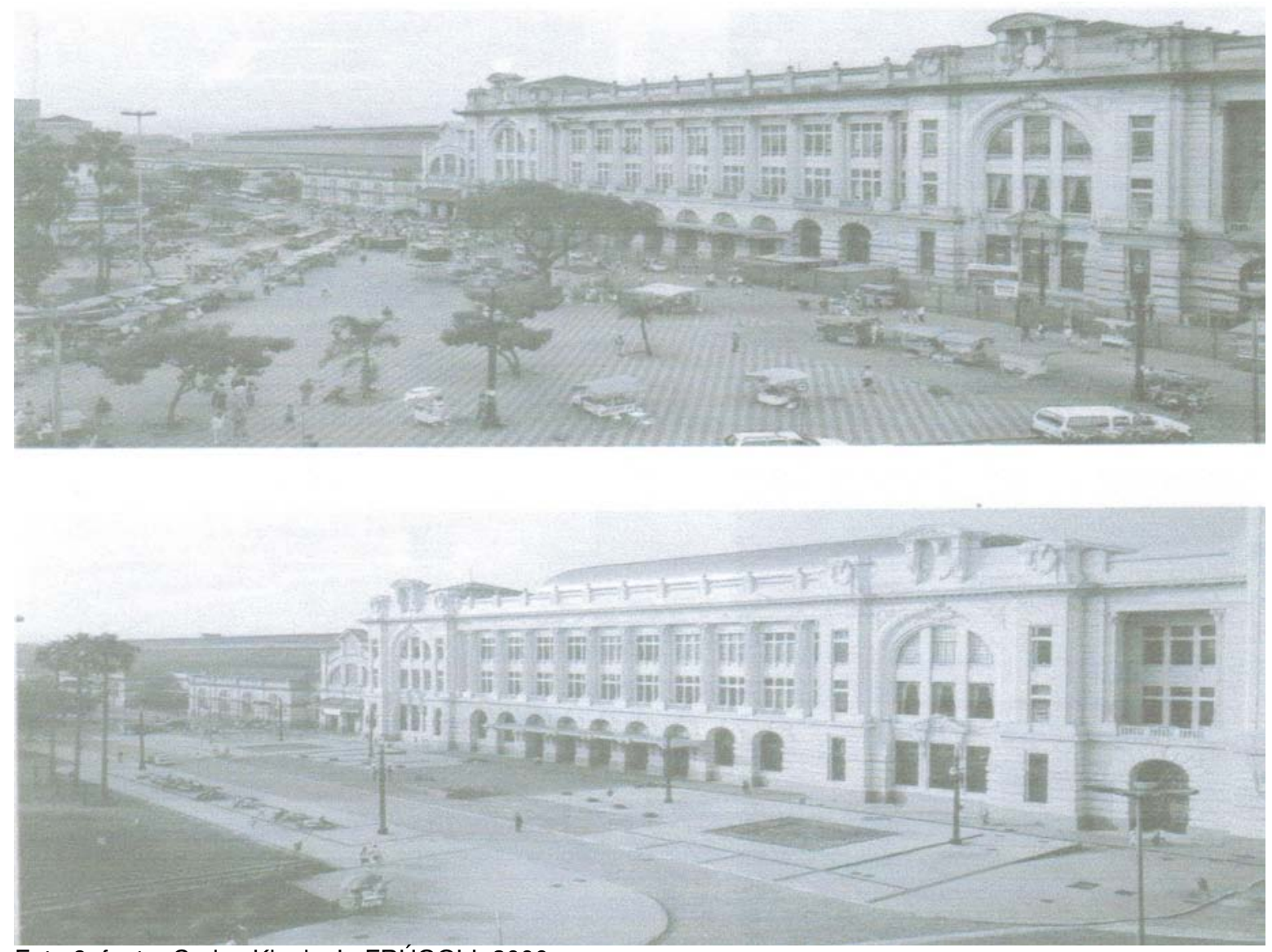

Foto 9. fonte: Carlos Kipnis. In FRÚGOLI, 2000.

Esta política de reorganização do espaço apontada por Frúgoli, continuou na gestão do Prefeito José Serra em 2006, quando a cidade de São Paulo acolheu 
o encontro mundial sobre revitalização urbana, condição que só foi possível porque "a cidade de São Paulo é membro da rede internacional Metropolis (Associação Mundial das Grandes Cidades) Fundada em 1995, com sede em Barcelona".(D.O.C. 25/03/06).

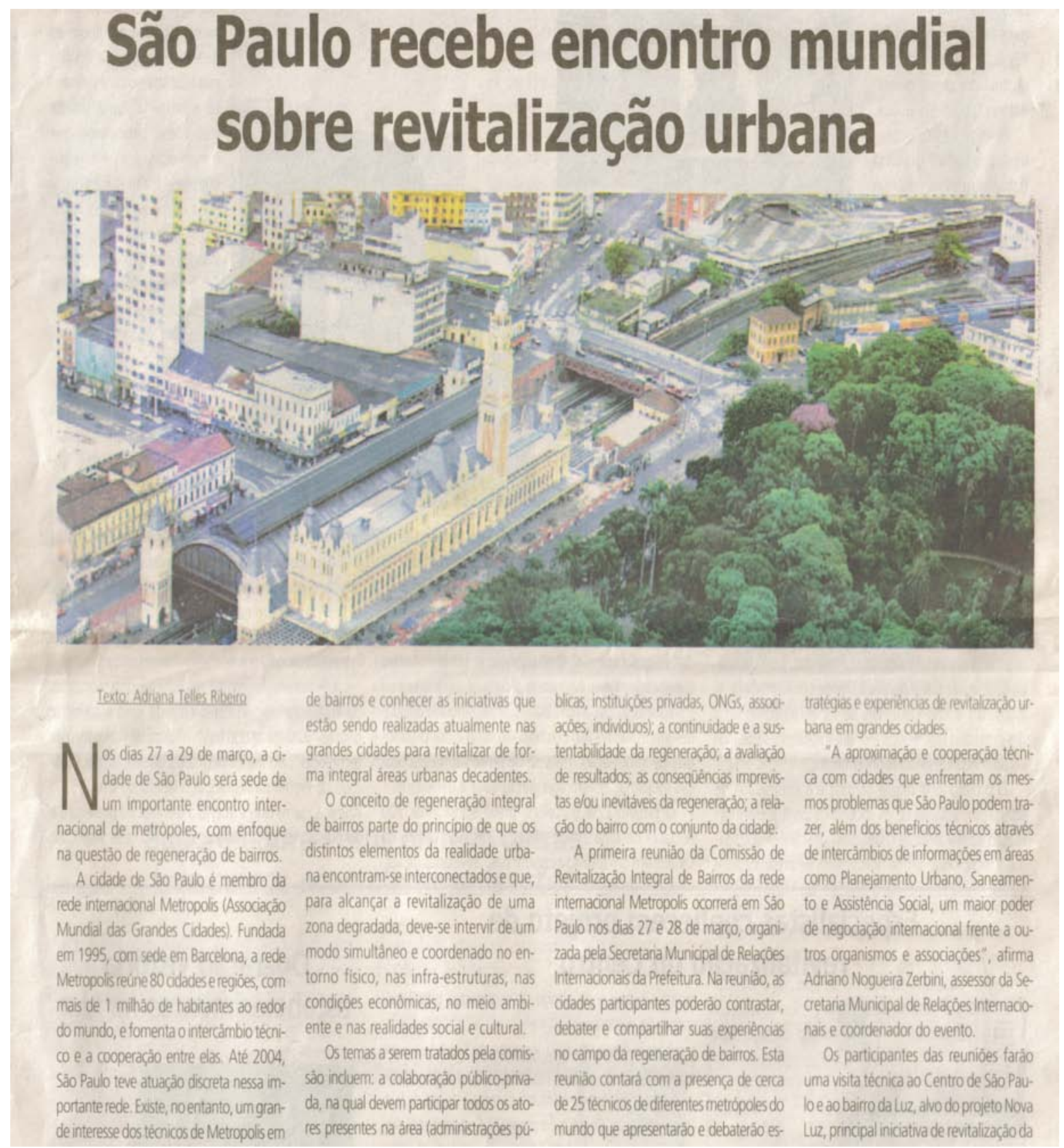

Fonte: Diário Oficial da Cidade de São Paulo 25 de março de 2006

No entanto, para a justificativa desse conjunto de ações, cria-se o discurso do "inevitável" - precisamos ser modernos e globais - utilizando para isso o 
reforço das imagens do espetacular como a que forma a paisagem Berrini voltada para a Marginal do Rio Pinheiros.

A Berrini nos oferece a oportunidade de perceber que a metrópole em sua centralidade é desdobrada e cada vez mais concentrada, à medida que os "novos centros", ligados às atividades do terciário moderno, são interligados ao Centro por canais de comunicação e, principalmente, necessitam do Centro para chancelar uma identidade, uma distinção em relação aos demais centros mundiais.

Neste sentido as operações urbanas: Centro e Água Espraiada servem para confirmar que o poder público, em um processo que se diz democrático, permitindo à sociedade civil através de associações e ongs a participação nas discussões que orientam os instrumentos de intervenção urbana, realiza os interesses econômicos de uma minoria, que recebe os benefícios da infraestrutura disponibilizada em determinada área da cidade, em detrimento de uma maioria que, até aparece nos planos estratégicos, mas são esquecidos como é o caso do projeto da Ponte Estaiada, que podemos ver abaixo na ilustração, onde também se contemplava a produção de um conjunto habitacional para a população local de baixo poder aquisitivo que não está sendo implementado, enquanto as obras da ponte caminham rapidamente, evidenciando que o uso do solo, do espaço urbano, está servindo como possibilidade de reprodução do capital, independente das necessidades sociais e, até mesmo, de uma maior racionalização do crescimento da cidade.

A produção do espaço nessa área está se realizando por meio de ações particulares atendendo a interesses muito pessoais (empresários, políticos e empreiteiras) que produzem pontes, viadutos, edifícios que mais congestionam e agravam os problemas urbanos visto que beneficiam a poucos em detrimento da maioria, no caso, o transporte público e as moradias populares foram abandonados em favor da valorização de uma centralidade financeira, da especulação imobiliária e do transporte individual, dos automóveis. 


\section{Avenida Roberto Marinho \\ segundo projeto da Prefeitura de São Paulo}

Preste atenção, no local hoje ocupado pela favela Jardim Edith, às construções populares.

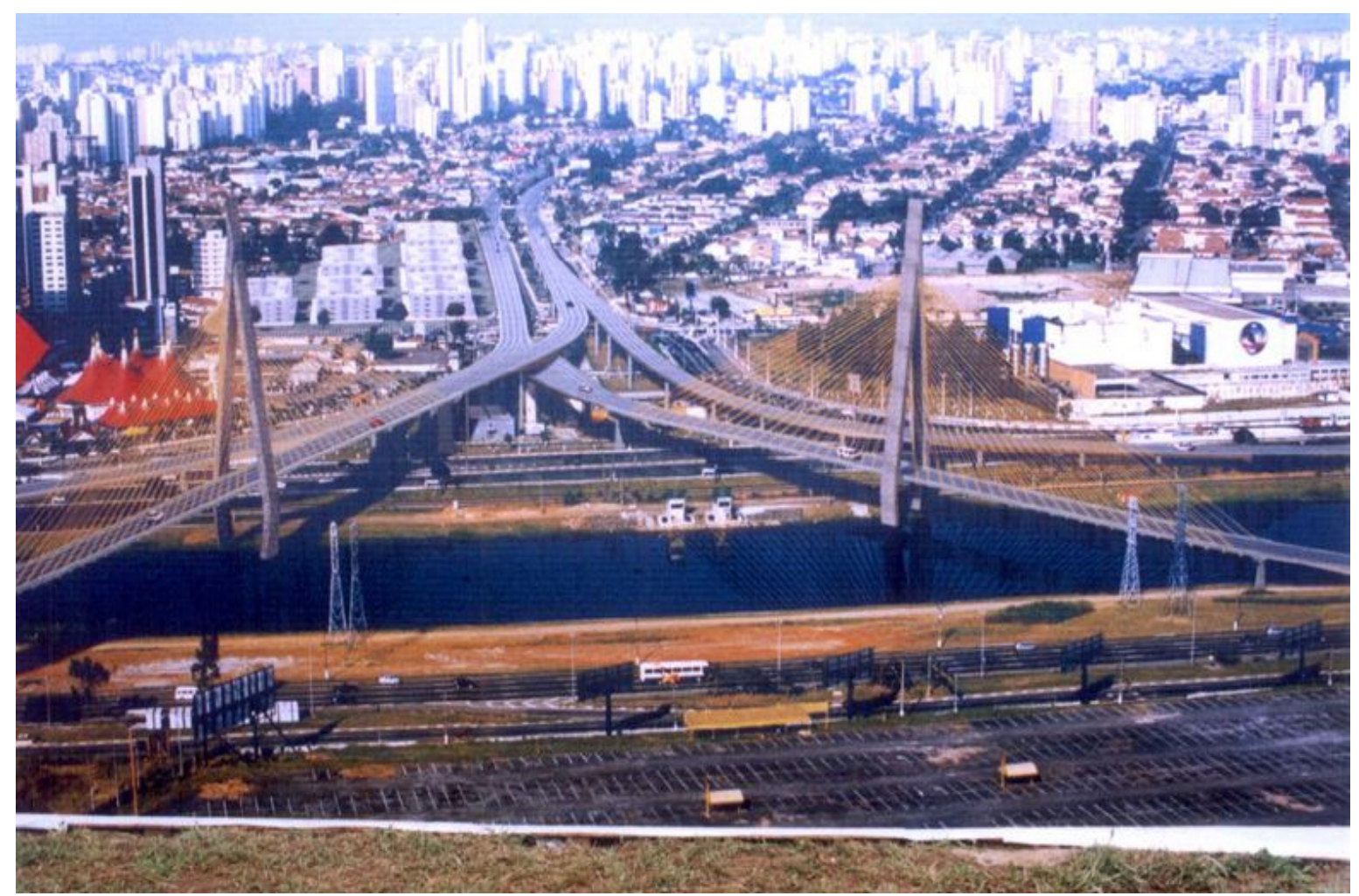

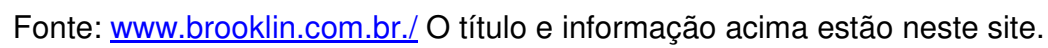

No mesmo local onde deveriam ser construídos os conjuntos habitacionais junto ao lado esquerdo do complexo viário, esquina da Avenida Jornalista Roberto Marinho e Engenheiro Luis Carlos Berrini, na ausência de uma solução do poder público, a população local se vira da seguinte maneira: 


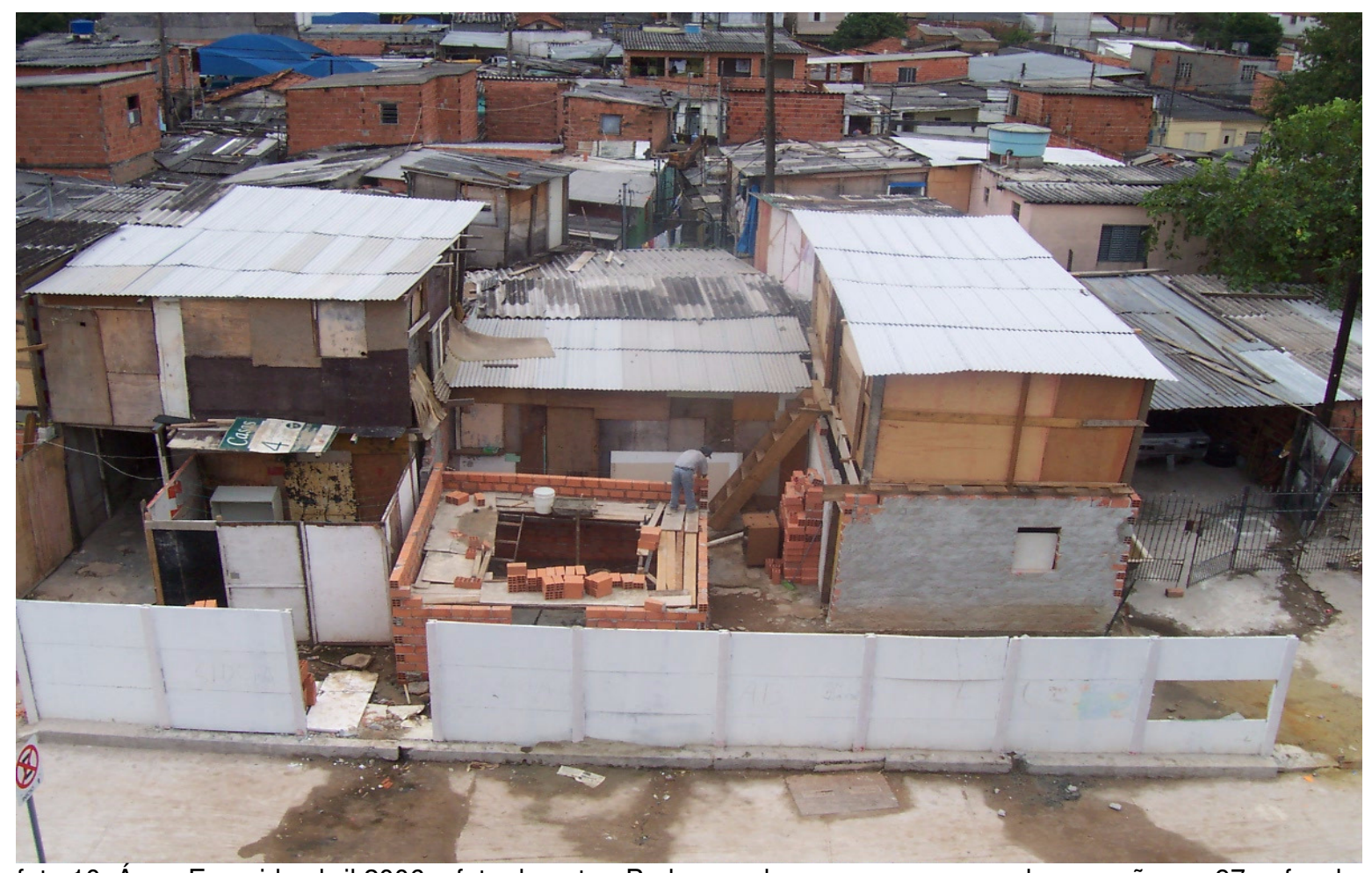

foto 10. Água Espraida abril 2006 - foto do autor. Podemos observar que, apesar da remoção em 97, a favela, não foi toda removida e, ao contrário, continua a ser reconstruída.

Constroem suas habitações com os recursos disponíveis, cada um da sua maneira ergue sua moradia sem nenhuma orientação, aqueles que conhecem o ofício de pedreiro e possuem uma pequena reserva para compra de materiais, como é possível ver na foto acima, fazem casas de alvenaria, enquanto os demais continuam a se equilibrar nos barracos de madeira e papelão.

Esse conjunto tão próximo, em que o poder dos agentes hegemônicos com o auxílio do poder público de um lado constrói mega-projetos e os agentes não hegemônicos de outro lado, sem amparo nenhum, produzem moradias precárias e barracos, é a cidade sendo construída nas relações conflituosas entre o poder hegemônico e o não-hegemônico. 


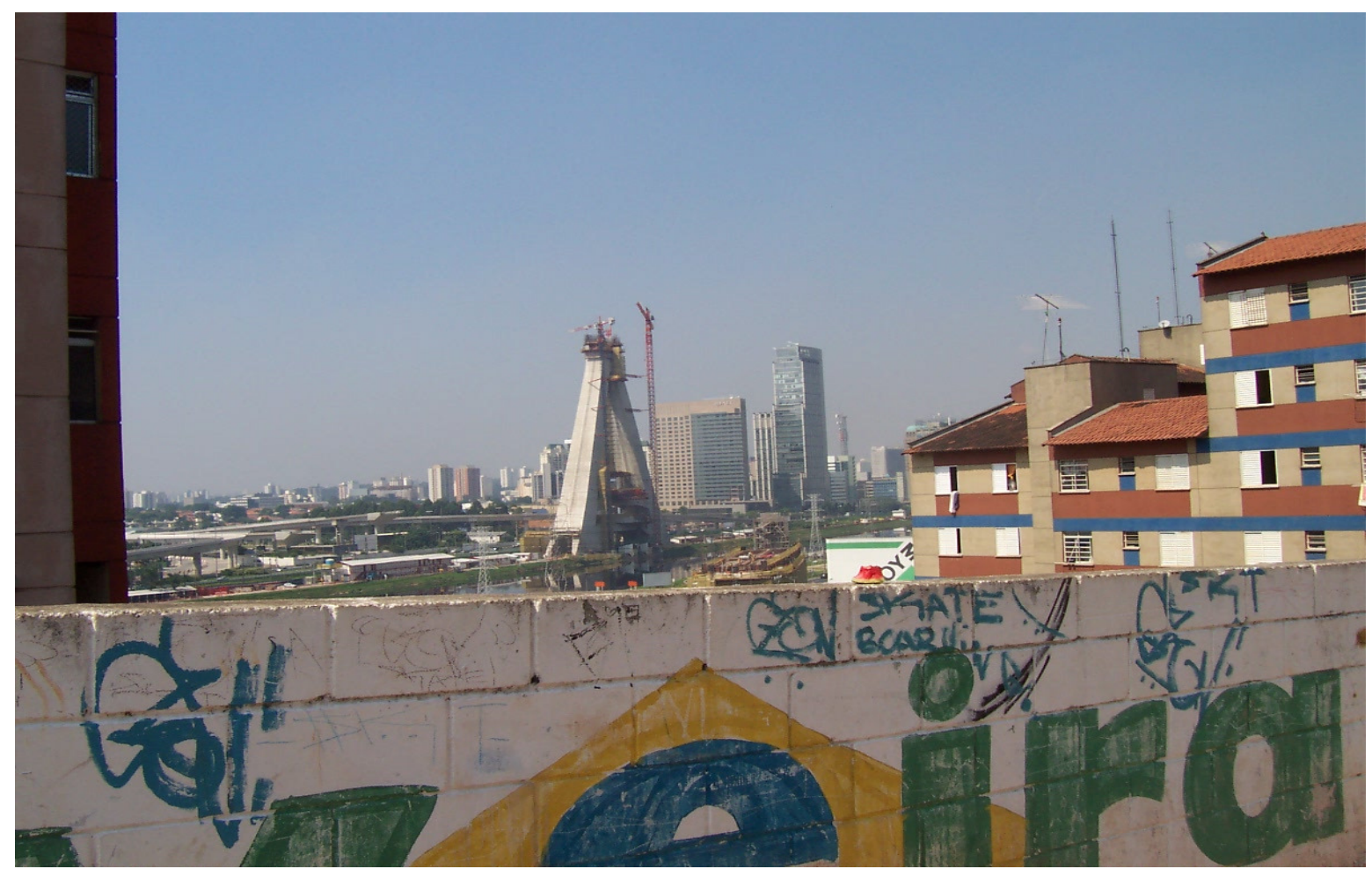

foto 11 - foto do autor abril 2007 - visão da futura Ponte Estaiada a partir da favela da mandioca - Real Parque Morumbi.

Na foto $n^{\circ} 11$ desponta a estrutura da Ponte se impondo sobre o Rio Pinheiros, uma obra de arquitetura notável que prende a atenção, dominando visualmente o espaço. Onde estão os agentes não hegemônicos?

De acordo com a LEI № 13.260 de 28 de dezembro de 2001 que estabelece as diretrizes urbanísticas para a Operação Urbana Água Espraiada, os não hegemônicos estão localizados como segue:

VII - Setor ZEIS, considerado Zona Especial de Interesse Social, tendo como objetivo a consolidação das famílias moradoras e a produção de Habitações de Interesse Social, determinado pelos seguintes perímetros, conforme indicado na Planta n. ${ }^{\circ}$ BE-04-7B-001:

a) inicia-se na Av. Eng. Luis Carlos Berrini, segue até a confluência com a R. Charles Coloumb, deflete à direta, segue até a confluência com a R Georg Ohm, deflete à direita, segue até a confluência com a Av. Água Espraiada, deflete à direita e segue até a confluência com a Av. Eng. Luis Carlos Berrini. (Fonte: SEMPLA)

Os agentes não hegemônicos, que neste caso estamos identificando como sendo as famílias moradoras na Zona Especial de Interesse Social 
(reconhecidas pela Lei $n^{\circ} 13.260$ de 2001), continuam no mesmo lugar e em condições piores. Com a ampliação da Avenida Água Espraiada (atual Roberto Marinho), para a construção das alças de acesso para o Complexo Viário Real Parque, as famílias moradoras do que restou do Jardim Edith, ficaram espremidas com o recuo do muro de proteção da Avenida, sendo obrigados a verticalizar ${ }^{12}$ suas moradias, aumentando a precariedade e o risco em que sobrevivem. Enquanto isso:

O prefeito de São Paulo vistoriou nesta terça-feira (29/05) as obras de construção da Ponte Estaiada sobre o rio Pinheiros, na Zona Sul, e assistiu à colocação do primeiro estai - conjunto de cabos de aço - que dará sustentação ao complexo. Primeira construção em curva e sustentada por hastes da América Latina, a Ponte Estaiada sobre o rio Pinheiros terá 144 estais, que consumirão 500 toneladas de cordoalha de aço, numa extensão de 378 mil metros. (http://www.prefeitura.sp.gov.br/portal/ - 29/05/07).

O Poder Público e os grupos hegemônicos com a disponibilização de recursos por meio da operação urbana consorciada Água Espraiada e o interesse em realizar onde era a várzea e sobre o Rio Pinheiros um Complexo Viário, um novo marco, um símbolo "moderno" na centralidade, promovem a reorganização do espaço em que a várzea vai sendo globalizada junto com sua periferia que, resiste, insiste em ficar no mesmo lugar.

\footnotetext{
${ }^{12}$ Com a diminuição da área disponível para construir um barraco e com o crescimento familiar, os moradores passaram a construir sobre o primeiro barraco, ficando barraco sobre barraco.
} 


\section{Da Capela Jesuíta à Centralidade São Paulo.}

"E a cidade se apresenta centro das ambições Para mendigos ou ricos e outras armações Coletivos, automóveis, motos e metrôs Trabalhadores, patrões, policiais, camelôs A cidade não pára, a cidade só cresce (...)". Chico Science, A cidade.

Como a centralidade de São Paulo, a cidade que não pára, a cidade que só cresce, se desdobrou até o centro Berrini e Marginal Pinheiros?

Será necessário recorrer à história da metrópole para em seu caminho tentar precisar cada termo. Ao dizermos a centralidade de São Paulo, que idéia nos vem? Por certo não é a de uma cidade pequena, mas sim a de uma grande cidade, uma metrópole, movimentada e rica. No entanto, quem pesquisa a origem de São Paulo depara-se com uma capela jesuíta, um tempo lento em que a pobreza era uma marca.

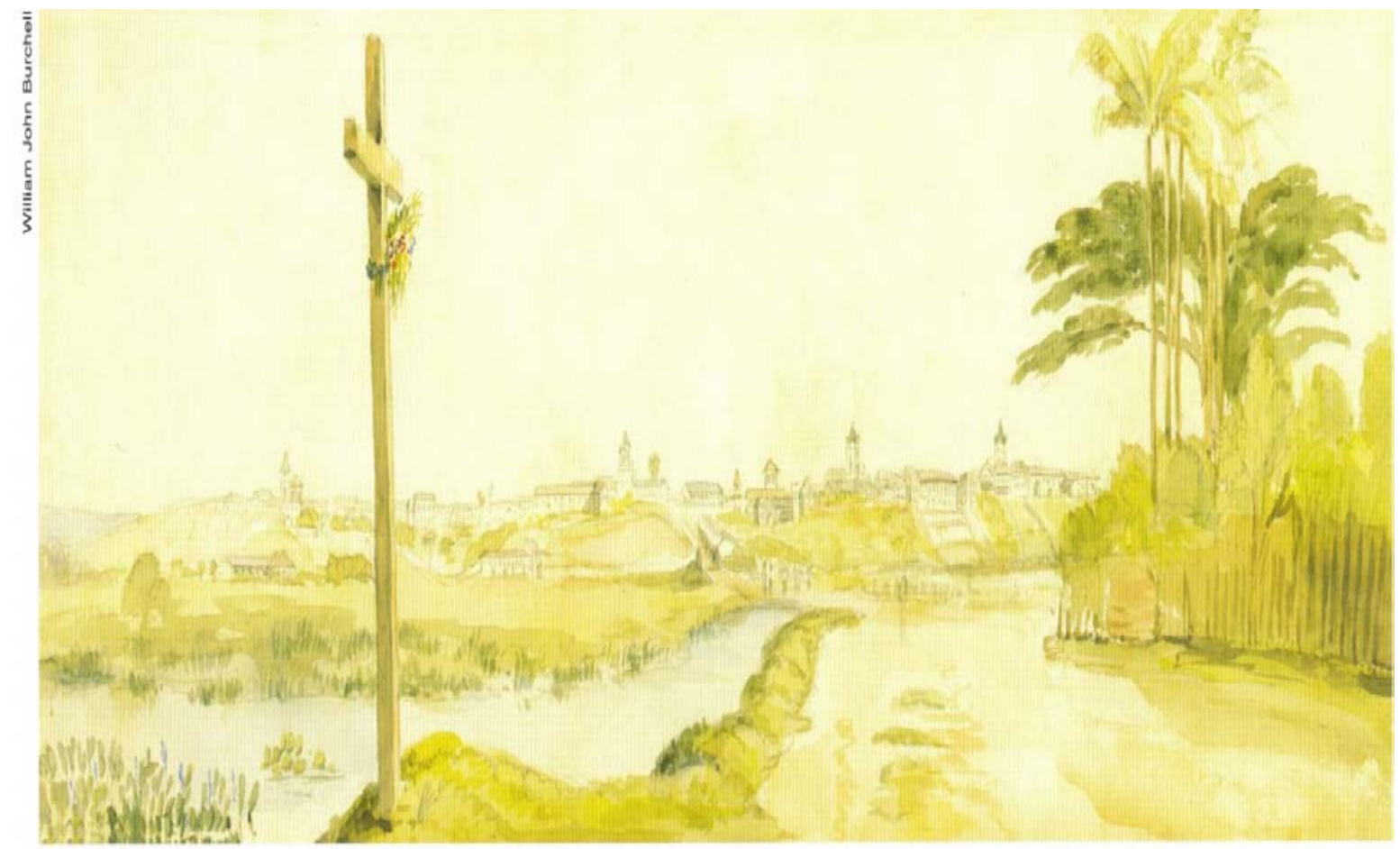

São Paulo vista da Estrada do Rio; no primeiro plano, proximidades do atual Largo do Bráse, ao fundo, da esquerda para a direita, a lgreja da Boa Morte, Convento e Ladeira do Carmo. a Torre do Recolhimento de Santa Teresa e as iareias da Sé e do Colécio (lápis e aquarela, 1827)

Fonte: São Paulo 450 anos: de vila a metrópole. 2004 
A passagem e transformação espacial entre o núcleo em que a capela era uma referência para o que hoje corresponde a área onde encontramos o Pátio do Colégio, mais precisamente, e em seus arredores a atual Praça da Sé, marco zero da cidade, com a suntuosa Catedral que a simboliza, abre a oportunidade de entender a expansão do Centro e o desdobramento de sua Centralidade.

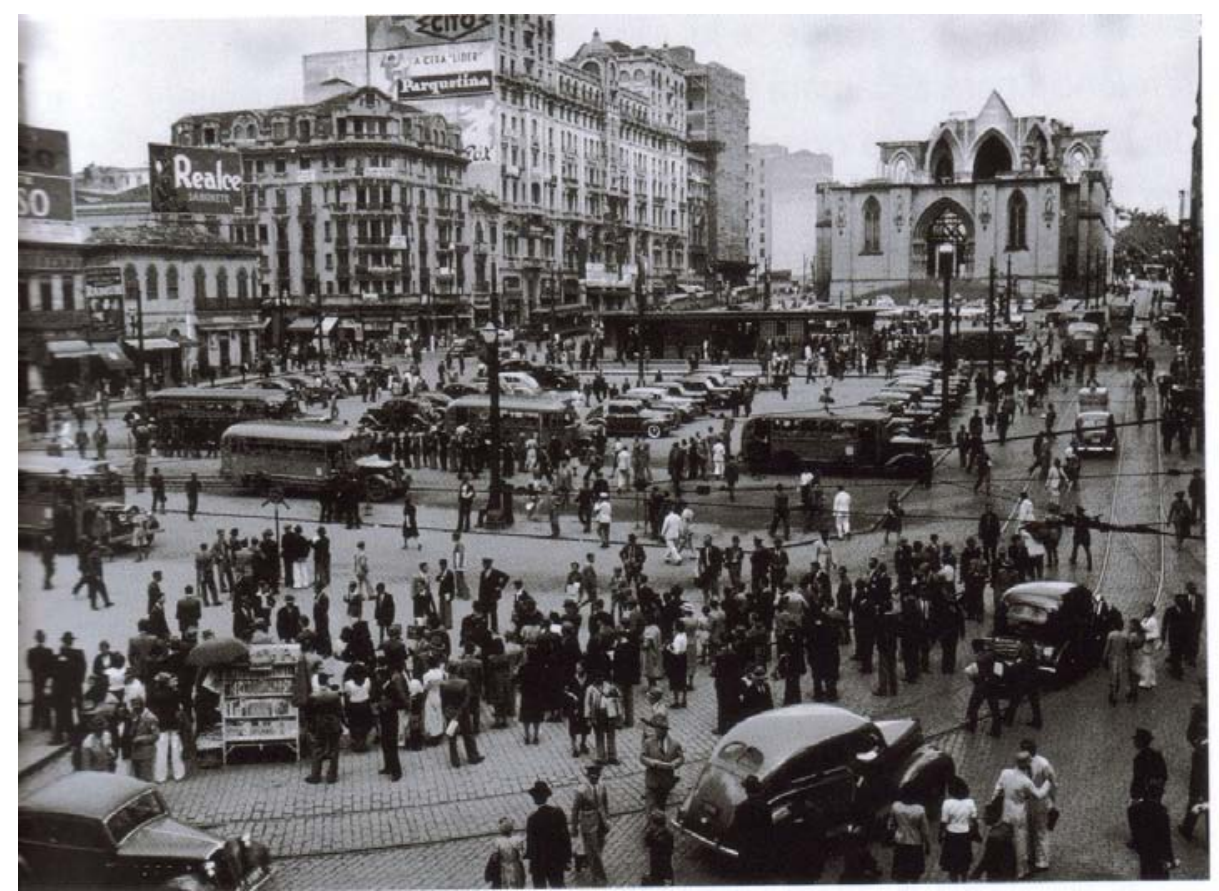

Fonte: São Paulo 450 anos: de vila a metrópole. 2004
Praça da Sé, tendo ao fundo a catedral em construção, c. 1940

Para nossa orientação vamos utilizar o mapa de expansão linear elaborado por Aroldo Azevedo onde podemos observar, logo abaixo, que no século XVI havia a Vila de São Paulo representada praticamente pela capela jesuíta.

\section{Expansäo linear da cidade de Säo Paulo em quatro séculos}

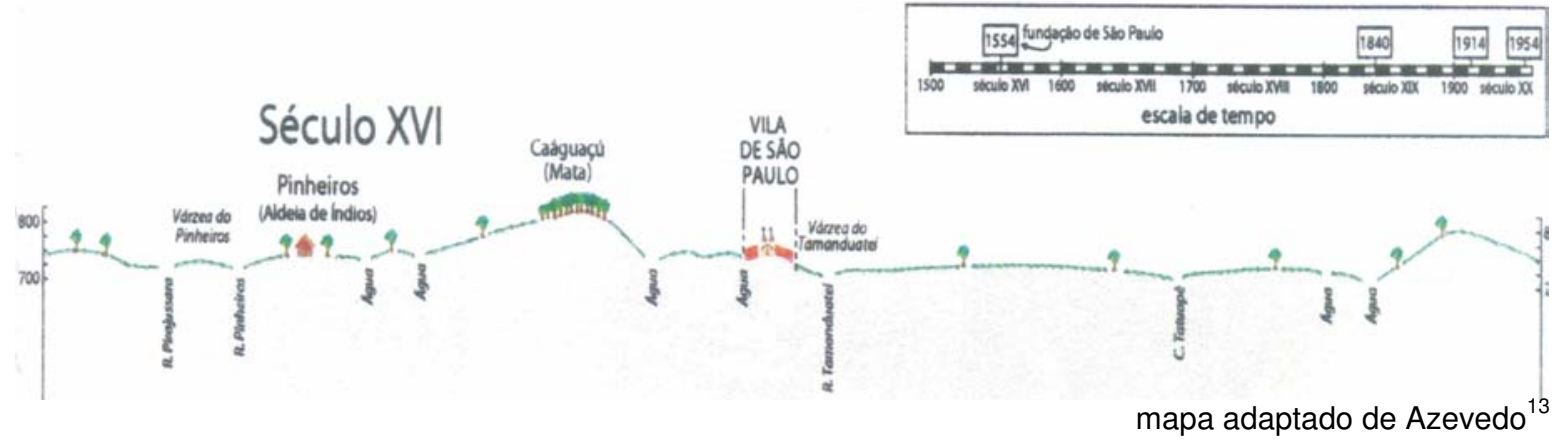

${ }^{13}$ Adaptação retirada de: Sergio Pinheiro dos Santos. São Paulo: de colégio a cidade mesopotâmica. 
No início do século XIX, já em 1840, com o status de cidade, porém não há, ainda, o registro cartográfico do centro, continua apenas a capela como símbolo.

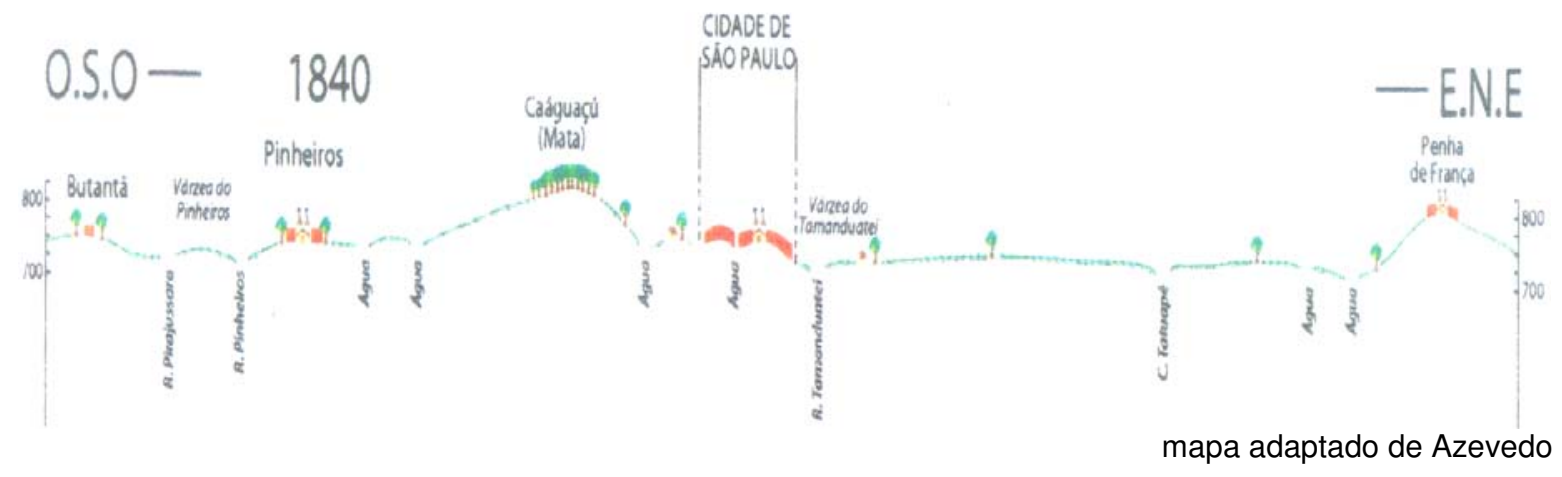

Apenas no início do século XX com a ampliação da ocupação das áreas do entorno, em que o movimento industrial desencadeado pela produção do café começa a condensar as atividades de produção, comércio e moradia, é que surge já cartografado ${ }^{14}$ e denominado como centro.

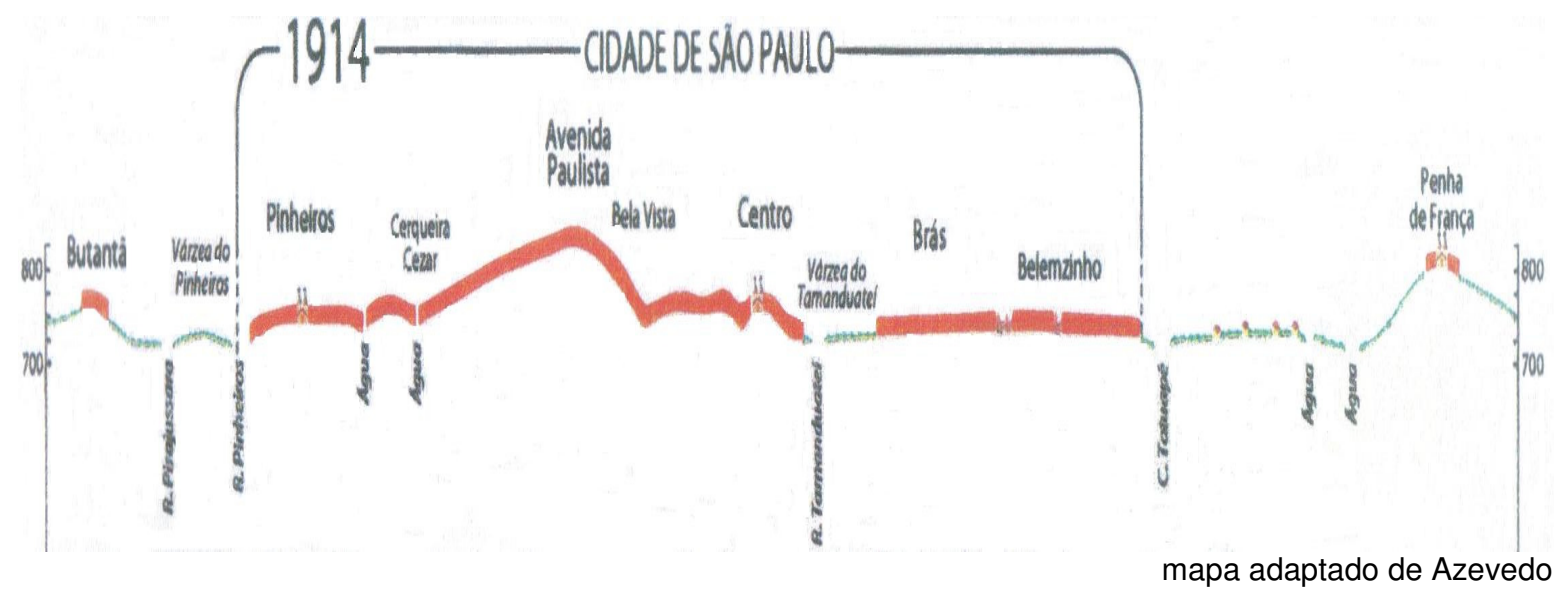

Vamos notar que após 1930, a atividade industrial impõe um ritmo mais intenso nas atividades que se aglomeram no centro, que vai ficando saturado, acarretando o seu desdobramento em 1954, onde temos o centro antigo em sua área inicial e centro novo ao lado.

\footnotetext{
${ }^{14}$ Vale lembrar que esse mapa foi elaborado por Azevedo nos anos 50 do século XX, quando a discussão conceitual de centro já se colocava na Geografia Brasileira. Ver Azevedo 1958.
} 


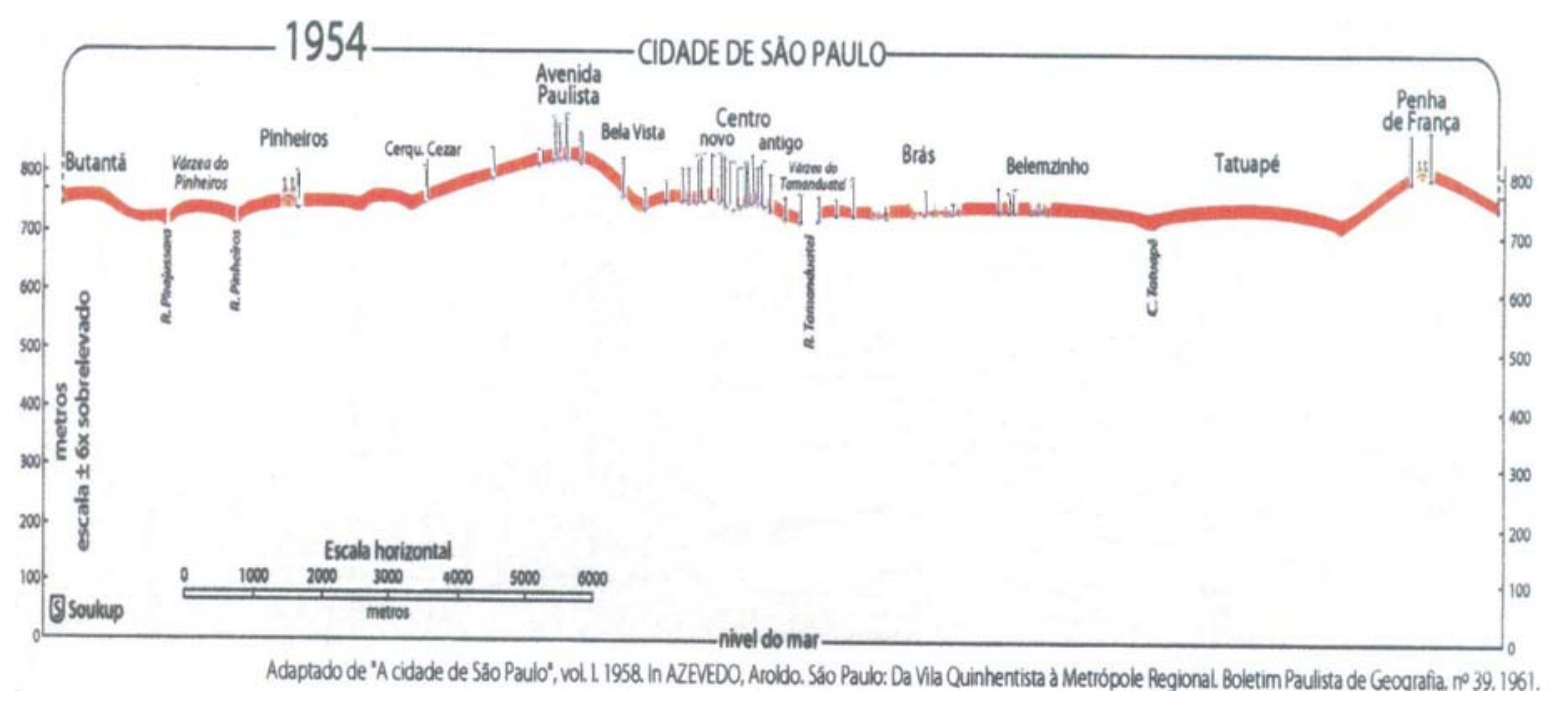

No entanto, precisamos posicionar que:

No interior da cidade, o centro não está necessariamente no centro geográfico, e nem sempre ocupa o sítio histórico onde esta cidade se originou, ele é antes de tudo ponto de convergência/divergência, é o nó do sistema de circulação, é o lugar para onde todos se dirigem para algumas atividades e, em contrapartida, é o ponto de onde todos se deslocam para a interação destas atividades aí localizadas com as outras que se realizam no interior da cidade ou fora dela... (SPOSITO, 1991: 6)

Se nem sempre o centro coincide com a origem histórica e o centro geográfico de uma cidade, existem casos, no entanto, que podem ter coincidido. Como foi o início de São Paulo onde o núcleo formado pela capela jesuíta era o ponto de convergência/divergência, ou seja, o lugar para onde todos se dirigiam para algumas atividades. Era, ao mesmo tempo, centro geográfico, histórico e de atividades.

Hoje a Praça da Sé e a Catedral não são mais o lugar para onde todas as classes se dirigem, entretanto concentra ainda diversas atividades. Esta situação nos faz perguntar novamente: esse centro perdeu a condição de concentração no espaço de atividades, de pessoas e de ser o nó do sistema de circulação para onde todos se dirigem ou ele simplesmente deixou de ser único? Houve deslocamento ou desdobramento do centro? Estas questões são fundamentais e retomaremos no decorrer do texto... 
Podemos dizer que o centro, em especial esse chamado de Principal, é um lugar da convergência/divergência, concentração no espaço de atividades, pessoas e o nó do sistema de circulação, que um dia foi único e hoje não é mais.

Contudo, em relação ao problema da nodalidade, da centralidade:

É preciso associar ao geográfico (as coisas que se passam no mesmo lugar) a uma referência ao tempo: é importante que as coisas que se passam no mesmo lugar se passem também lá onde outras coisas se passaram. A continuidade histórica é importante. Aliás, estes aspectos são suportados por outra coisa além do funcional. Podemos fazer nossas compras tanto no centro urbano quanto nas grandes superfícies, mas isso não tem exatamente o mesmo caráter. É preciso acrescentar aqui a dimensão simbólica e o imaginário... (RONCAYOLO, 1986:19).

Precisamos de uma referência, de uma localização não só geográfica e histórica, mas também simbólica e imaginária e conforme o dizer do próprio Roncayolo: "nós não somos enraizados, nos enraizamos".

Nesse sentido Abraham Moles contribui para esclarecer nossa relação com as centralidades quando diz que:

Nós gostamos de cidade por razões diversas, ligadas às lembranças pessoais, à memória histórica, aos gêneros de vida que levamos, por puras razões estéticas, porque elas são eminentemente vivas ou, ao contrário, porque elas cessaram de viver, ou por várias destas razões ao mesmo tempo (Aliás, geralmente nos gostamos apenas de fragmentos de cidades). (MOLES, 1986:16).

Como gostamos de fragmentos da cidade, a centralidade ou centralidades também chega a ser afetiva para cada um de nós. Contudo para Lefebvre a centralidade engloba muito mais que o geográfico, o histórico, o simbólico, o imaginário e o afetivo, ela resulta também das relações de produção e das relações sociais e refere-se ao urbano (processo induzido pela industrialização), onde existe a necessidade de reunir, de atrair, ser a referência do encontro e: 
... Desde o início, na vizinhança do zero inicial, o urbano encontrava-se em germe, a caminho. Como o instrumento, desde a lasca de pedra ou o bastão brandido, como a linguagem e os conceitos desde o primeiro lugar demarcado. A centralidade ad-vém desde o primeiro re-colhimento e da primeira re-coleção de objetos dispersos na natureza, desde o primeiro ajuntamento ou amontoado de frutos. Ela anunciava sua realização virtual. Desde o princípio, reunir, amontoar, recolher é algo de essencial na prática social; é um aspecto racional da produção que não coincide com a atividade produtiva, mas dela não se dissocia...(LEFEBVRE, 2004:115).

Como Lefebvre aceitamos que a centralidade ad-vém desde o primeiro re-colhimento e a fundação de São Paulo, obra dos jesuítas, e pelo menos nesse início, não coincidiu com a atividade produtiva, mas dela não se dissociou, seguindo o modelo de cidade medieval, tendo a capela como centro. Este centro inicial, histórico, já apontava o urbano a caminho enquanto reunia e dispersava a população em torno da centralização da Igreja que, naquele momento, também acumulava o poder administrativo, à medida em que o poder real se fazia presente através desta estrutura.

Até este momento era a atividade administrativa timidamente e a atividade religiosa de maneira intensa que exerciam a atração simbólica e imaginária para a população que começava a se formar junto à Vila de São Paulo.

Com a elevação para a condição de cidade, o poder político passa a atrair mais as pessoas para a região e, em seu entorno, já começa a surgir pólos de povoamentos como os da Penha de França, Pinheiros e Butantã.

Ainda que no início tenha sido o poder institucional da Igreja associado ao poder real que organizou o centro da cidade, seu crescimento passou a ser ordenado posteriormente pelo poder público, por isso utilizaremos a partir do século XIX, como instrumento para entender o processo histórico do centro e das centralidades de São Paulo, as intervenções públicas em que:

... podemos destacar quatro períodos distintos. Um primeiro, até 1890-1930, que pode ser chamado de estéticosanitarista, um segundo período modernizador, de 1930 a 1965, e um terceiro, tecnocrático-funcionalista, de 1965 a 
1988, e finalmente um quarto, de 1988 até hoje, que pode ser chamado de 'planejamento flexível'(SOMEKH, 1993: 333)

No primeiro período, as dificuldades que a cidade apresentava por ter crescido e mudado rapidamente, trazia preocupações de como organizar seu espaço em relação a crescente população pobre, daí as idéias estéticas e sanitárias. Para Somekh (1993) a classe dominante, muito mais ligada às metrópoles européias, busca reproduzir o espaço nos moldes dos países dominantes. São Paulo tenta ser transformada numa pequena Paris. Em relação ao segundo período:

... Com o advento da industrialização, a outrora sossegada cidade voltada aos serviços e negócios financeiros associados à exportação do café - a atividade econômica dominante no estado de São Paulo até a década de 1930 foi transformada num espaço caótico. Na virada do século, a construção era intensa: erguiam-se novas fábricas uma atrás da outra, e residências tinham que ser construídas rapidamente para abrigar as ondas de trabalhadores chegando a cada ano. As funções não eram espacialmente separadas, as fábricas eram construídas perto das casas, e comércio e serviços intercalavam-se com residências. (CALDEIRA, 2003: 213)

Com a industrialização o ritmo da cidade muda drasticamente e o centro, como diz Lefebvre, implode-explode, ou seja, o adensamento das atividades sem a separação das funções, torna o centro saturado, congestionando a circulação e as trocas, fazendo-o implodir, como se fosse destruído por dentro; e a enorme concentração de pessoas, riquezas, atividades, coisas etc., explode o espaço caótico projetando seus fragmentos múltiplos.

Este contexto faz ganhar força a idéia de que o centro necessita de uma organização e de que é necessário racionalizar sua expansão. Neste momento surge o "Plano de Avenidas" que consistia em uma proposta de Ulhoa Cintra e Prestes Maia, que abrangia o sistema viário com circulação e transportes e diretrizes para embelezamento, arruamento, zoneamento, expansão urbana e legislação tributária. Neste plano Prestes Maia, segundo Libâneo, apud Frúgoli Jr. (2000:54): 
via no Centro três grandes defeitos: era exíguo e incapaz de comportar a vida de uma grande cidade; de difícil acesso e estava sempre congestionado. Somente outro centro, em nova localização, teria condições de resolver esses entraves. O Perímetro de Irradiação abriria vias de expansão e penetração, convergindo para pontos diferentes do núcleo central. O novo centro se instalaria para além do Anhangabaú, em direção à Rua Barão de Itapetininga, São João e Avenida Ipiranga. Caberia ao poder público executar a tarefa, socializando os custos.

Aqui se configura a centralidade de São Paulo, o local da convergência e concentração de empresas, a industrialização passa a comandar o processo de reprodução urbana, a partir da primeira fase de industrialização brasileira de 19101940, e da Segunda de 1940-60. No entanto, o processo de:

expansão do centro foi acompanhado da emergência de subcentros, face ao seu crescimento territorial e à conseqüente impossibilidade de permanência de um único centro cumprindo o papel comercial e de serviços, por causa do aumento das distâncias ao centro principal e da ineficiência do sistema viário e de transporte coletivo, dificultando o acesso a ele.

Tais subcentros podem ser caracterizados como áreas onde se alocam as mesmas atividades do centro principal com diversidade comercial e de serviços, mas em escala menor, e com menor incidência de atividades especializadas... (Sposito, 1991: 09 e 10)

Podemos citar como exemplos de subcentros, em São Paulo, o de Pinheiros, o Largo Treze de Maio em Santo Amaro entre outros. Os subcentros não são, necessariamente, continuidade de uma centralidade primordial, são centros regionais no interior da estrutura urbana.

O terceiro período de 1965 a 1988, de acordo com Somekh, corresponde a cidade terciária de expansão dos serviços. Mas é nesse período que a lei de zoneamento, criada em 1972, provoca uma escassez de terra verticalizável através do estabelecimento restrito a $10 \%$ da cidade do maior coeficiente de aproveitamento.

Por outro lado, segundo Spósito (1991:10), é a partir da década de 70 nas áreas metropolitanas, e dos anos 80 nas cidades médias, que ocorre a 
generalização de uma tendência à localização de atividades terciárias tipicamente centrais, ao longo de vias de maior circulação de veículos, traduzindo-se na configuração de eixos comerciais e de serviços importantes.

Quanto ao quarto período, de 1988 até hoje, se refere ao planejamento flexível. Em 1988 a lei de zoneamento pôde ser modificada pelo artigo 30 do Plano Diretor de Jânio Quadros e pela promulgação da lei de operações interligadas.

Chamada inicialmente de Lei de Desfavelamento, veio atender à pressão do setor imobiliário no sentido de alteração dos índices urbanísticos da legislação de zoneamento utilizando-se de um discurso pretensamente social (Somekh, 2002: 336).

A participação do poder público demonstra, neste caso, que apesar dos discursos do Estado mínimo, o mesmo continua a ser fundamental para garantir as possibilidades de reprodução do capital, principalmente quando é necessário facilitar sua espacialização.

Aqui retomamos a questão do desdobramento da centralidade. Estou utilizando o termo Centralidade São Paulo para referir a um conjunto formado pelo centro Principal, o Centro Paulista, O centro Faria Lima e o Centro Berrini e o que já se anuncia Centro Marginal Pinheiros. Conforme Sposito (1991:11) essas novas centralidades são caracterizadas:

pela localização de atividades tipicamente centrais, mas de forma especializada. Ou seja, nelas não se reproduz a alocação de todas as atividades tradicionalmente centrais, mas selecionadamente de algumas destas. Daí, a caracterização do processo como desdobramento da centralidade...

A cidade mundial de São Paulo possui, neste sentido, uma centralidade relacionada ao processo de espacialização do capital, ou seja, da extensão das áreas de concentração do terciário moderno para concretizar a reprodução do capital. Este fenômeno que começa a ser realizado a partir das décadas de 70 e 80 com o desenvolvimento tecno-científico que permitiu a conexão instantânea de algumas áreas internacionais, criando redes. Neste momento, a centralidade já podia ser apontada nesta região como: 
... uma lógica que tende a se impor como " ordem estabelecida" que define o modo como a cidade vai-se reproduzindo a partir da reprodução, realizada pela ação dos promotores imobiliários, das estratégias do sistema financeiro e da gestão política, às vezes de modo conflitante, em outros momentos de modo convergente... (CARLOS, 2001:15).

Em um movimento de reprodução realizado pelos promotores imobiliários, das estratégias do sistema financeiro e da gestão política estão sendo reproduzidas formas na centralidade de São Paulo para possibilitar a reprodução do capital, onde:

A localização dos modernos escritórios na cidade de São Paulo revela uma atividade que requer a concentração, o que gera uma centralidade efetiva. As exigências de um novo eixo empresarial na metrópole, em virtude das transformações do processo de produção, criam a necessidade de um espaço determinado, com características que permitam não só o adensamento da região com a construção em altura, mas com moderna tecnologia, apoiada em densa rede viária, ligando pontos-chave da metrópole, como a proximidade com o aeroporto e serviços novos... (CARLOS, 2001:26/27)

O desdobramento da centralidade de São Paulo, que tinha sua unicidade no centro Principal, para o centro Paulista e posteriormente o centro Berrini e Marginal Pinheiros demonstram que sua gênese vincula-se, também, a conexão com as áreas de comando internacionais e, ao contrário do que se tem dito, o Centro Principal não perdeu sua importância, ele implodiu-explodiu e agora, para sustentar seu desdobramento, requer um reforço de sua centralidade.

Esse desdobramento da centralidade pode ser visualizado cartograficamente da seguinte forma, mapa $n^{\circ} 5$ Estabelecimentos segundo setores de atividades, $n^{\circ} 6$ Lançamentos comerciais no mercado imobiliário e $n^{\circ} 7$ Salas de teatro, shows e concertos: 


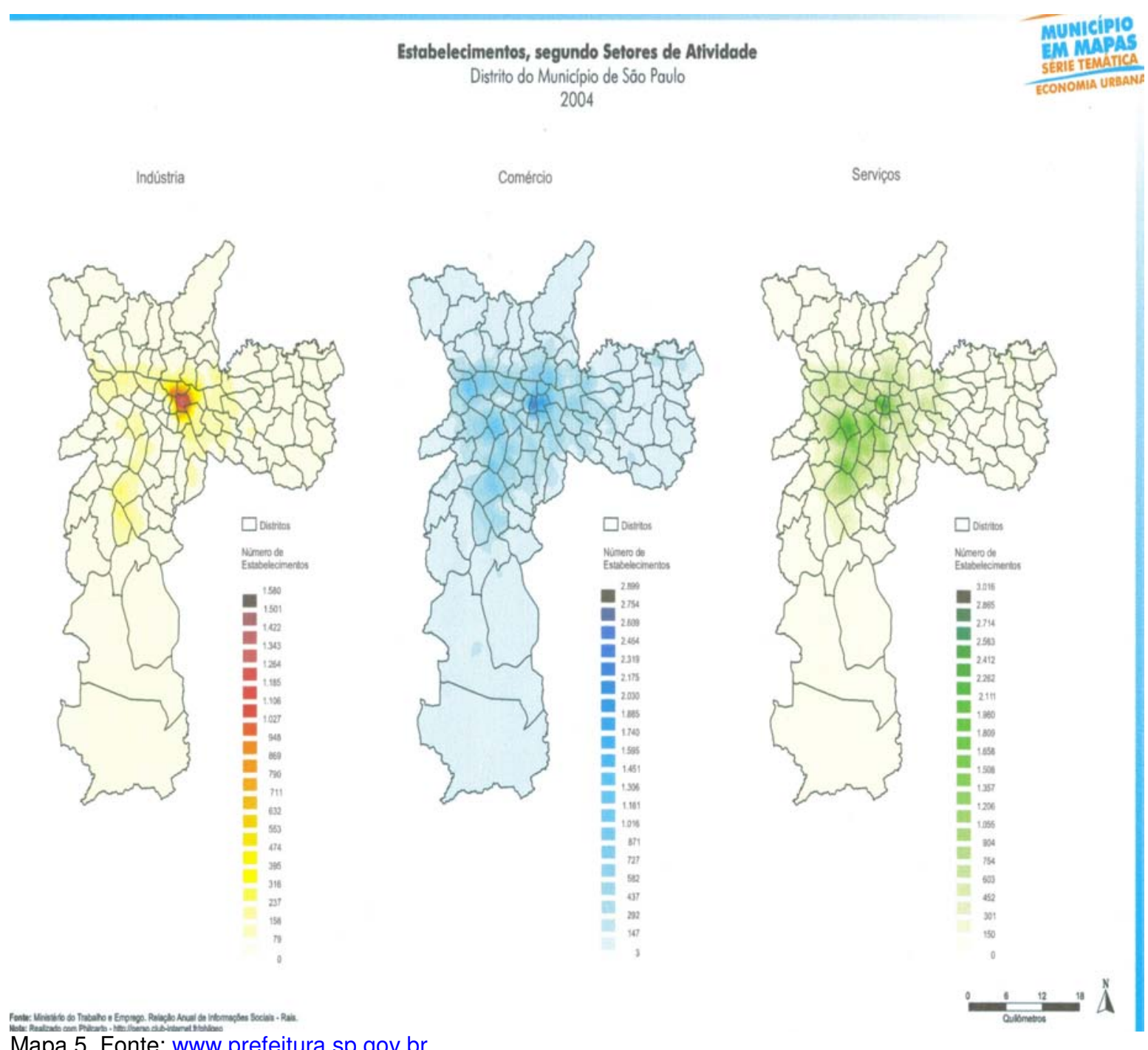

Mapa 5. Fonte: www.prefeitura.sp.gov.br.

É possível no mapa $n^{\circ} 5$, que cartografa a concentração dos três setores da economia: indústria, comércio e serviços, perceber que existe um deslocamento dessas atividades no interior do município e, mesmo com o desdobramento da centralidade, continuam em boa parte, concentradas na região central da cidade. Podemos observar que existe uma mancha dessas atividades que se desloca do Centro para a região da Avenida Paulista, Avenida Faria Lima, Avenida Engenheiro Luís Carlos Berrini, Marginal Pinheiros e Santo Amaro. 


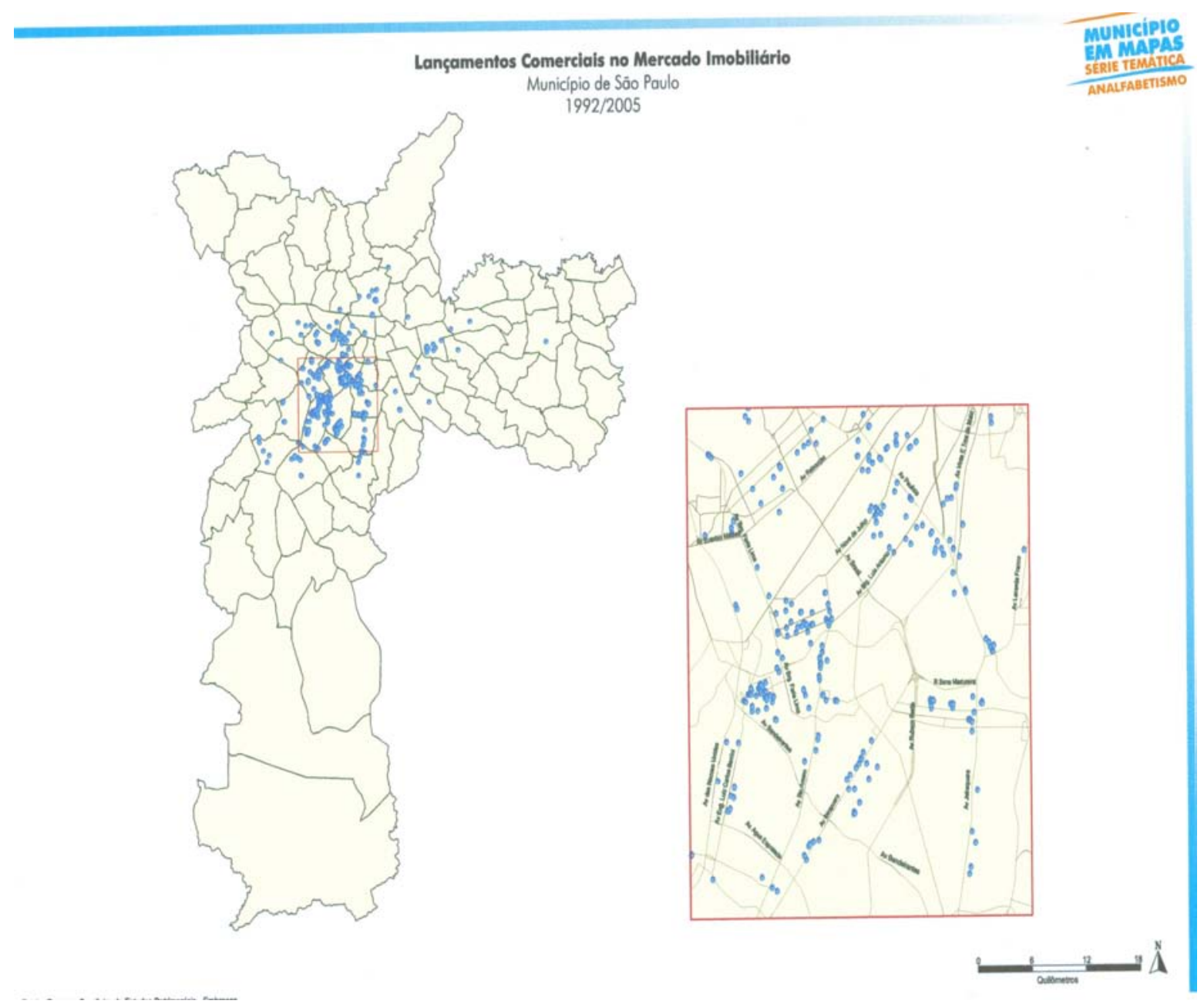

Mapa 6. Fonte: www.prefeitura.sp.gov.br

Seguindo o deslocamento das atividades econômicas podemos constatar que o mercado imobiliário comercial concentra seus lançamentos tanto no Centro como em toda a extensão do vetor sudoeste, disponibilizando os edifícios de escritórios para atender a toda essa população de empresários, profissionais liberais de alto e médio nível e investidores internacionais.

No mapa $n^{\circ} 7$ se confirma que as atividades de entretenimento e cultura acompanham o desdobramento da centralidade, no entanto, ainda permanecem no Centro a maior quantidade de salas de teatro, shows e concertos, com destaque para os equipamentos públicos como, por exemplo: Casa São Paulo, Teatro Municipal e Pinacoteca do Estado. 


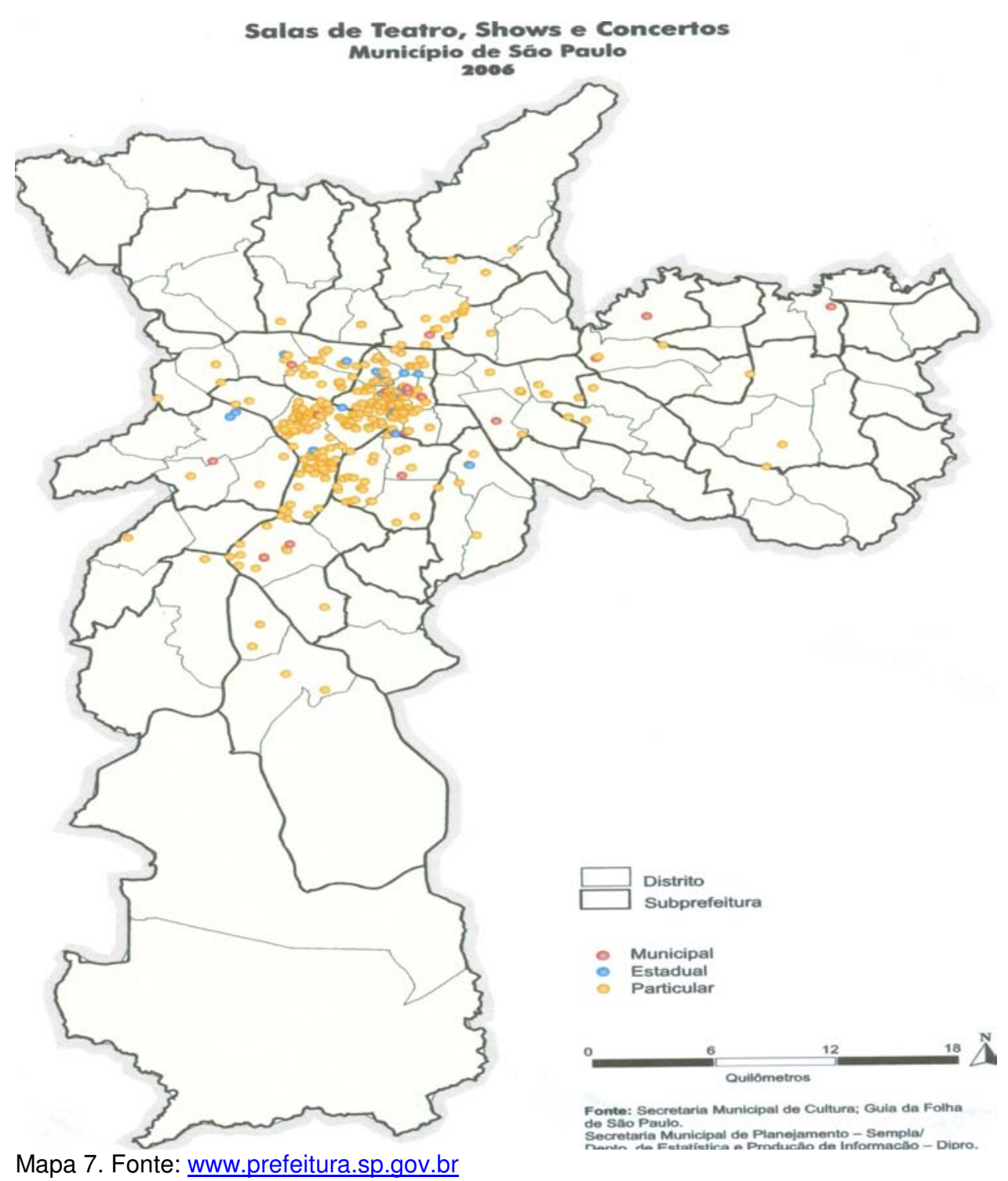

Assim presenciamos ao conjunto de obras que acontece paralelo e simultaneamente ao centro Berrini e no Centro Principal.

Neste momento podemos responder que o movimento que produziu o Centro de São Paulo é o mesmo que continua a reproduzir sua centralidade, ou seja, produz e reproduz suas contradições, e é nesse contexto que localizamos o centro Berrini, um desdobramento do terciário que se concentrava apenas no Centro e foi se desdobrando no centro Paulista, centro Faria Lima e atualmente centro Berrini se desdobrando para as margens da marginal do Rio Pinheiros, acompanhando um processo de raridade do espaço associado à especulação imobiliária, interesses políticos e econômicos. 
É o movimento urbano produzindo a cidade que não pára, a cidade que só cresce, implode - explode, expande - concentra, "esse espaço urbano é contradição concreta".(LEFEBVRE, 2004:46).

Deste modo, podemos perceber que a cidade cresce contraditoriamente: da capela jesuíta, criando uma centralidade única que vai se desdobrando e, nesse processo, temos desde centros do terciário moderno como também as favelas e, no nosso caso, a favela da Mandioca no Real Parque Morumbi.(foto 12)

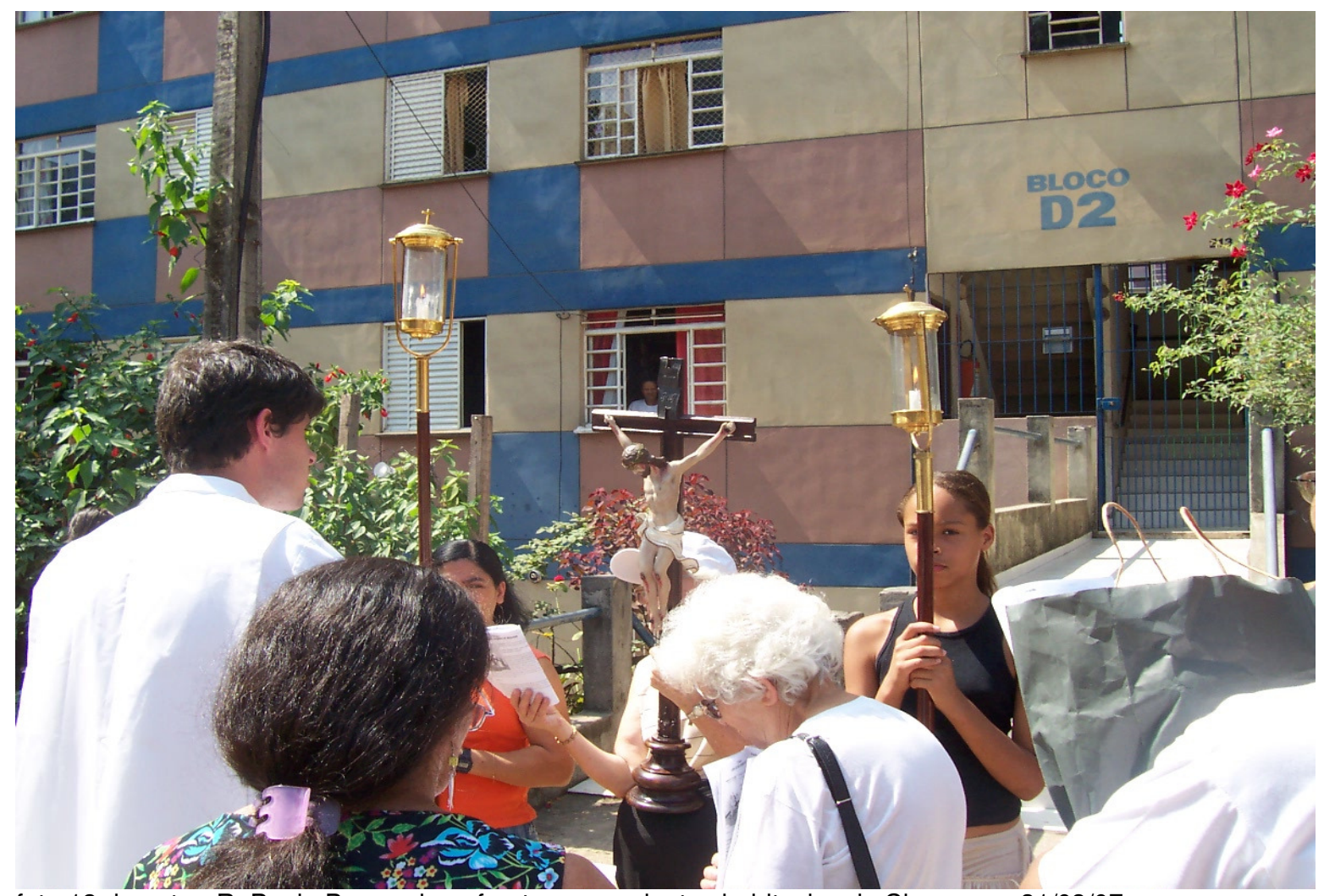

foto 12 do autor. R. Paulo Bourroul em frente aos conjuntos habitacionais Cingapura. 31/03/07

O ritual católico que podemos observar na foto acima pode ser entendido como uma permanência cultural que remonta à fundação da Cidade de São Paulo que, como vimos na História Oficial da Cidade, tem sua origem ligada à construção de uma capela jesuíta.

Mas a cidade se concretiza (mapa 8) por meio dos grupos de agentes que participam, de forma contraditória, desse processo de construção da cidade e de sua centralidade: os agentes hegemônicos e os agentes não hegemônicos. 


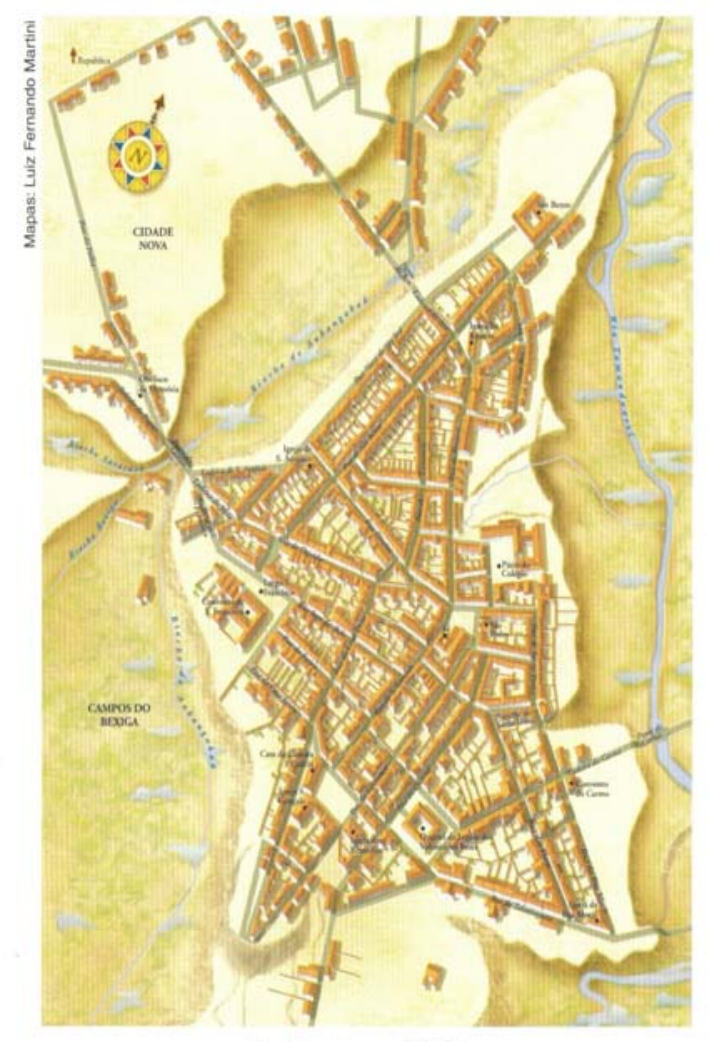

São Paulo em 1824

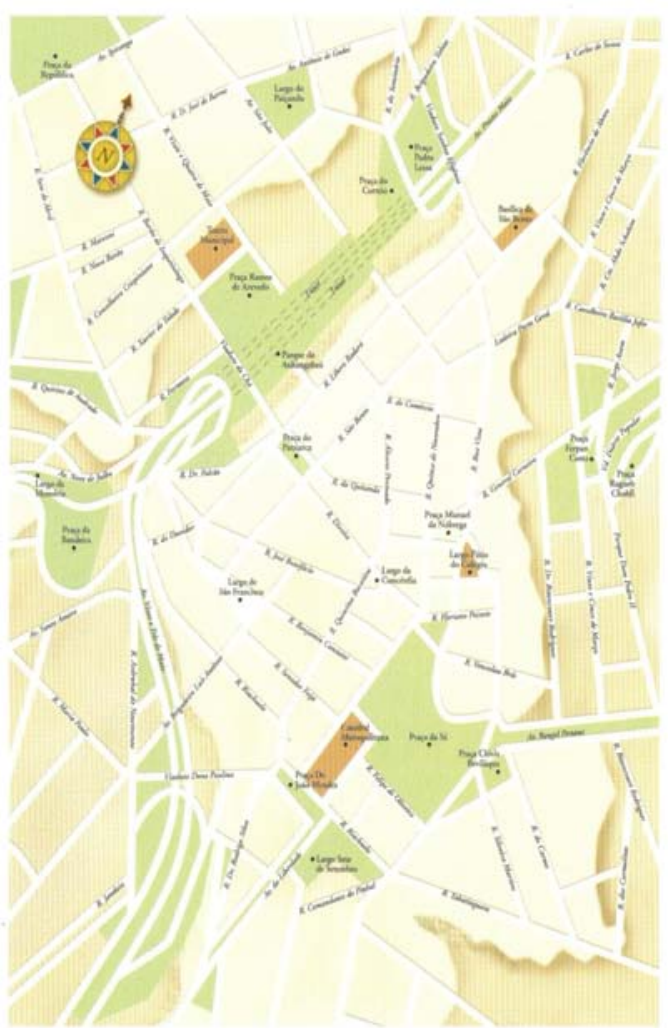

Mesma região em 2004

Mapa 8. Fonte: São Paulo 450 anos: de vila a metrópole. 2004

A seguir procuramos identificar, analisar e expor a ação dos agentes hegemônicos. 


\section{Os agentes hegemônicos.}

"As coisas têm peso massa, volume, tamanho, tempo, forma, cor, posição, textura, duração, densidade, cheiro, valor, consistência, profundidade, contorno, temperatura, função, aparência, preço, destino, idade, sentido, as coisas não têm paz".

Arnaldo Antunes

Ao produzir e modificar as coisas, o ser humano também produz e reproduz o espaço, assim como são influenciados e reagem às coisas e ao espaço reproduzido. As pessoas, o espaço e as coisas não têm paz.

Diante do movimento de contradição imanente das pessoas, coisas, espaços, "o espaço urbano que se define (...) pelo vetor nulo (...) onde cada ponto, virtualmente, pode atrair para si tudo o que povoa as imediações: coisas, obras, pessoas" (LEFEBVRE 2004:93), analisamos neste capítulo as relações econômicas e políticas para tratar dos agentes hegemônicos que consideramos os atuais detentores desses poderes.

Nossa preocupação parte de uma constatação na produção e uso do espaço urbano que é dialético:

Mas na medida em que algumas relações de produção e de propriedade não sejam transformadas, a centralidade sucumbirá ao golpe dos que utilizam tais relações em seu proveito.(LEFEBVRE, 2004:93).

No sentido exposto por Lefebvre, o processo por meio do qual a centralidade de São Paulo está se desdobrando, pode estar servindo ao interesse de alguns que utilizam as relações de produção e de propriedade em seu proveito. 
Nossa pesquisa aponta, de acordo com vários estudos e, em especial o de SASSEN ${ }^{15}$, que "a economia global (...) é uma economia que precisa ser produzida". É nesse sentido que agentes hegemônicos mundiais/locais induzem o processo de relações necessárias para realizar a globalização do capital.

As ações desencadeadas, por esses agentes hegemônicos, produzem e reorganizam atividades e elementos no espaço (prédios tecnológicos, praças financeiras, centros de informação, etc) para que o fluxo e as trocas aconteçam em alguns territórios nacionais. Isso se deve ao fato de que "os mercados nacionais e globais, bem como as operações globalmente integradas, requerem lugares centrais, onde se exerça o trabalho de globalização" (SASSEN, 1998:13), como é o caso, no Brasil, de algumas localidades específicas na cidade de São Paulo.

A essas localidades específicas, ou como diz SASSEN, "lugares centrais", denominamos de Centralidade São Paulo (o conjunto formado pelo centro Principal, o centro Paulista e o centro Berrini) por ser a região de maior afluxo dos investimentos e instalações de escritórios internacionais, o que nos leva a concordar que:

Una economía-mundo acepta siempre un polo, un centro representado por una ciudad dominante, antiguamente una ciudad-Estado y hoy en día una capital, entendiéndose por tal una capital económica... ${ }^{16}$ (BRAUDEL, 1985: 87-88).

A expansão da economia-mundo indica um dos fatores, a necessidade de reprodução do capital, que atualmente induz no interior de uma capital econômica como São Paulo, a seleção de algumas áreas específicas para ser um pólo, como uma centralidade.

Como geógrafos focamos os elementos espaciais, buscando analisar os elementos/instrumentos implantados às ações econômicas/sociais que se concretizam nas paisagens da centralidade de São Paulo. Entendemos que essas

\footnotetext{
15 Saskia Sassen. Globalização da economia e as cidades in Schiffer, Sueli Ramos (org). Globalização e estrutura urbana. São Paulo, 2004: 42

2 Tradução do autor: "Uma economia-mundo aceita sempre um pólo, um centro representado por uma cidade dominante, antigamente uma cidade-Estado e hoje em dia uma capital, entendendo-se por tal uma capital econômica...”.
} 
ações não são isoladas, fazem parte de um mesmo processo de reprodução do capital e das relações sociais que são construídas no espaço e construtoras do mesmo, são também influenciadas pelos novos elementos (materiais/simbólicos) introduzidos nesse espaço.

Esses novos arranjos são baseados em objetos geográficos cujo funcionamento é, cada vez mais, interdependente e sistêmico, e constituem a base de práticas sociais hegemônicas igualmente sistêmicas. Graças à nova arquitetura urbana e à qualidade técnico-científicainformacional do meio ambiente construído, eleva-se o patamar da racionalidade sem outra razão que a do lucro, ainda que não se manifeste exclusivamente de forma mercantil. O simbólico se torna um coadjuvante precioso do mercadológico. É essa a danação da metrópole contemporânea. (SANTOS, 1998: 78).

Seguindo esta linha de raciocínio, São Paulo por ser uma metrópole de indiscutível importância econômica é impactada pelas ações econômicas/sociais hegemônicas mundiais, que interferem no seu espaço, dotando-o de novos elementos que, ainda que busquem a homogeneidade dos lugares, não se realizam em plenitude já que para além da visão técnica, lógica, da dimensão concebida do espaço, há também vida, cheiros, presenças. A relação, ainda que muitas vezes não desejada pelos agentes hegemônicos, implica em movimentos que produzem paisagens bastante heterogêneas, e aparentemente muito contraditórias: uma dotada de infra-estrutura e inovação ao lado de outra área "abandonada", sem infra-estrutura básica inclusive, tanto pelo poder público quanto pelo privado. Ainda que contraditórias, elas se completam, isto é, estão articuladas e fazem parte de um todo contraditório e desigual que pode ser percebido na foto 13 . 


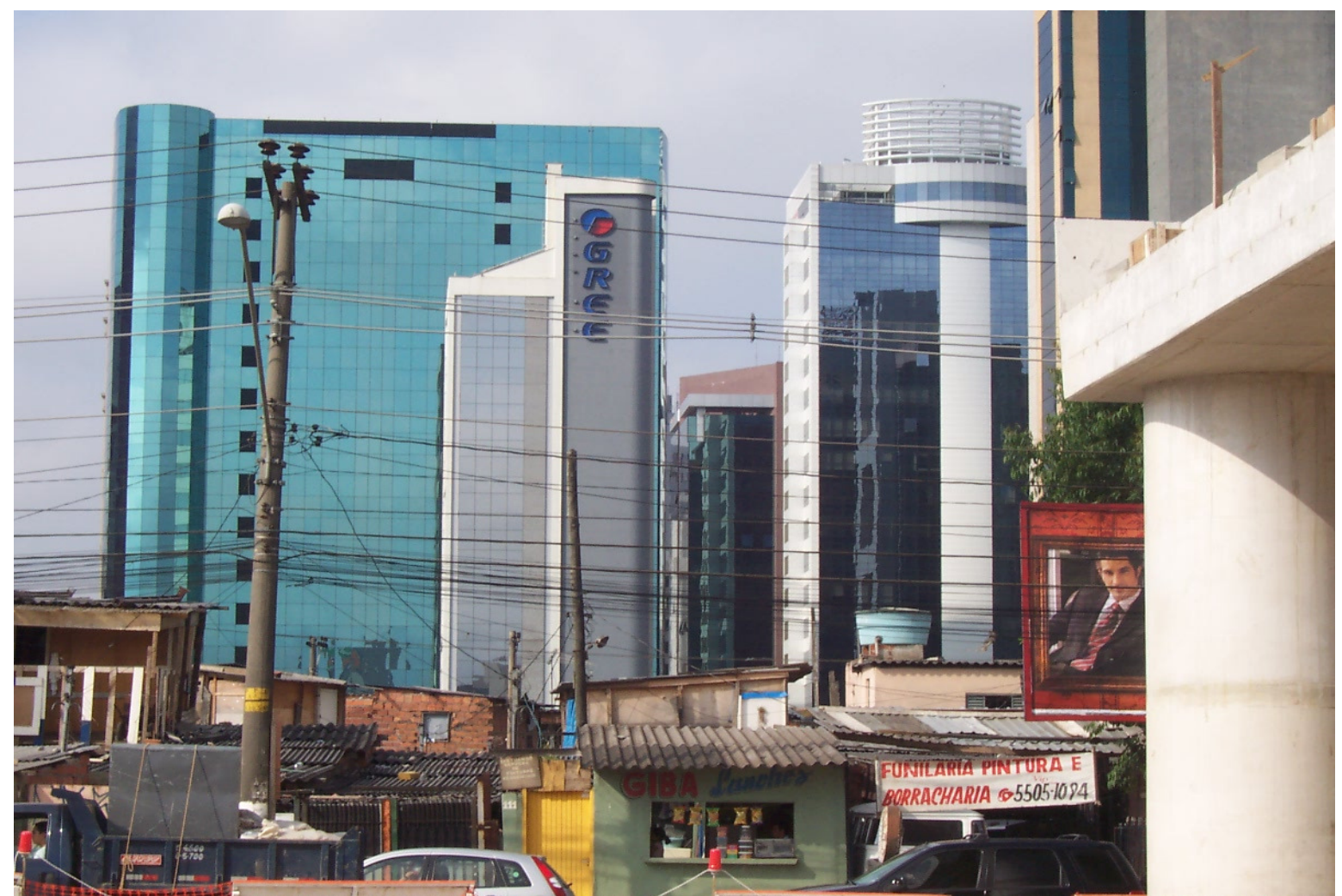

foto 13 do autor outubro de 2005 - visão a partir da Água Espraiada, resíduos do Jardim Edith com edifícios da Berrini ao fundo e a construção das alças de acesso à Avenida Jornalista Roberto Marinho (antiga Água Espraiada).

Assim, este espaço reproduzido traduz as contradições da própria sociedade, denunciando espaços de promoção e riqueza para alguns que, necessariamente, produzem e reforçam uma periferia imediata de impossibilidade e pobreza para outros, e:

Como convém a um país onde as leis são aplicadas de acordo com as circunstâncias, o chamado Plano Diretor está desvinculado da gestão urbana (...) A habitação social, o transporte público, o saneamento e a drenagem não têm o status de temas importantes (ou centrais, como deveriam ser) para tal urbanismo. O resultado é: planejamento urbano para alguns, mercado para alguns, lei para alguns, modernidade para alguns, cidadania para alguns... (MARICATO, 2002: 124/125).

Consideramos que esses espaços e as ações econômicas/sociais que os reproduziram e por eles são influenciadas, podem criar isolamentos, mas não são isolados, pertencem ao mesmo processo da reprodução do capital, o que nos leva a entender que a globalização também é como define GIDDENS: 
A intensificação das relações sociais em escala mundial, que ligam localidades distantes de tal maneira que acontecimentos locais são modelados por eventos ocorrendo a muitas milhas de distância e vice-versa. Este é um processo dialético porque tais acontecimentos locais podem se deslocar numa direção anversa às relações muito distanciadas que os modelam... (1991: 69 e 70).

A globalização é, dessa maneira, compreendida como sendo um processo de mobilidade do capital que ocorre em várias escalas (global, regional e local), como parte do processo de expansão e reprodução capitalista e, portanto, de produção das relações econômicas/sociais que, para se materializar, vincula elementos na reorganização do espaço que é o:

... lugar onde se manifesta a vida, o espaço é condição, meio e produto da sociedade humana em toda a sua multiplicidade. Reproduzido ao longo de um processo histórico ininterrupto de constituição da humanidade do homem, este é também o plano da reprodução. Ao produzir sua existência, a sociedade reproduz, continuamente, 0 espaço... (CARLOS, 2001: 11).

Desse modo, "ao produzir sua existência, a sociedade reproduz continuamente, o espaço", o que nos remete a LEFEBVRE (1974:32) ao afirmar que "Cada modo de produção possui, por hipótese, seu espaço apropriado", portanto, é possível dizer que as relações orientadas no modelo do capitalismo contemporâneo têm produzido os atuais espaços, tanto globais quanto locais, a fim de atender suas necessidades de produção, gerando espaços de excelência dotados de infra-estrutura/inovação capazes de permitir a reprodução e fluidez do capital, concomitantemente deixando outros espaços no esquecimento e fora das condições mínimas para que seus habitantes tenham pelo menos uma vida digna, embora estejam também inseridos, ainda que precariamente, como alerta HAESBAERT ${ }^{17}$ (2002), no processo global.

\footnotetext{
${ }_{17}$ Para o autor "coexistem hoje diversas formas de experimentar "iintegralmente" o espaço. Se convivemos num mundo tão desigual e com uma massa tão grande de excluídos, é evidente que vamos encontrar desde a elite que efetivamente usufrui da multiterritorialidade e da multi-escalaridade planetária, até os grupos mais fixados à terra, como os indígenas e os pequenos agricultores, e aqueles quase totalmente excluídos, como muitos dos sem-teto defendendo suas marquises ou seus abrigos em viadutos nas ruas das grandes cidades..."
} 
O processo desencadeado nas relações econômicas, políticas e sociais, que é dialético, concretiza-se na espacialidade reproduzida e o lugar torna-se estratégico para o entendimento de como a globalização, ao mesmo tempo que resulta de ações específicas (objetivadas por alguns indivíduos ou grupos em reproduzir o capital) também é vivenciada pelos demais (foto 14), seja de forma direta ou indireta, realizando a produção de espaços que tanto podem limitar como favorecer as ações sociais dos vários segmentos da população no sentido de sua apropriação espacial.

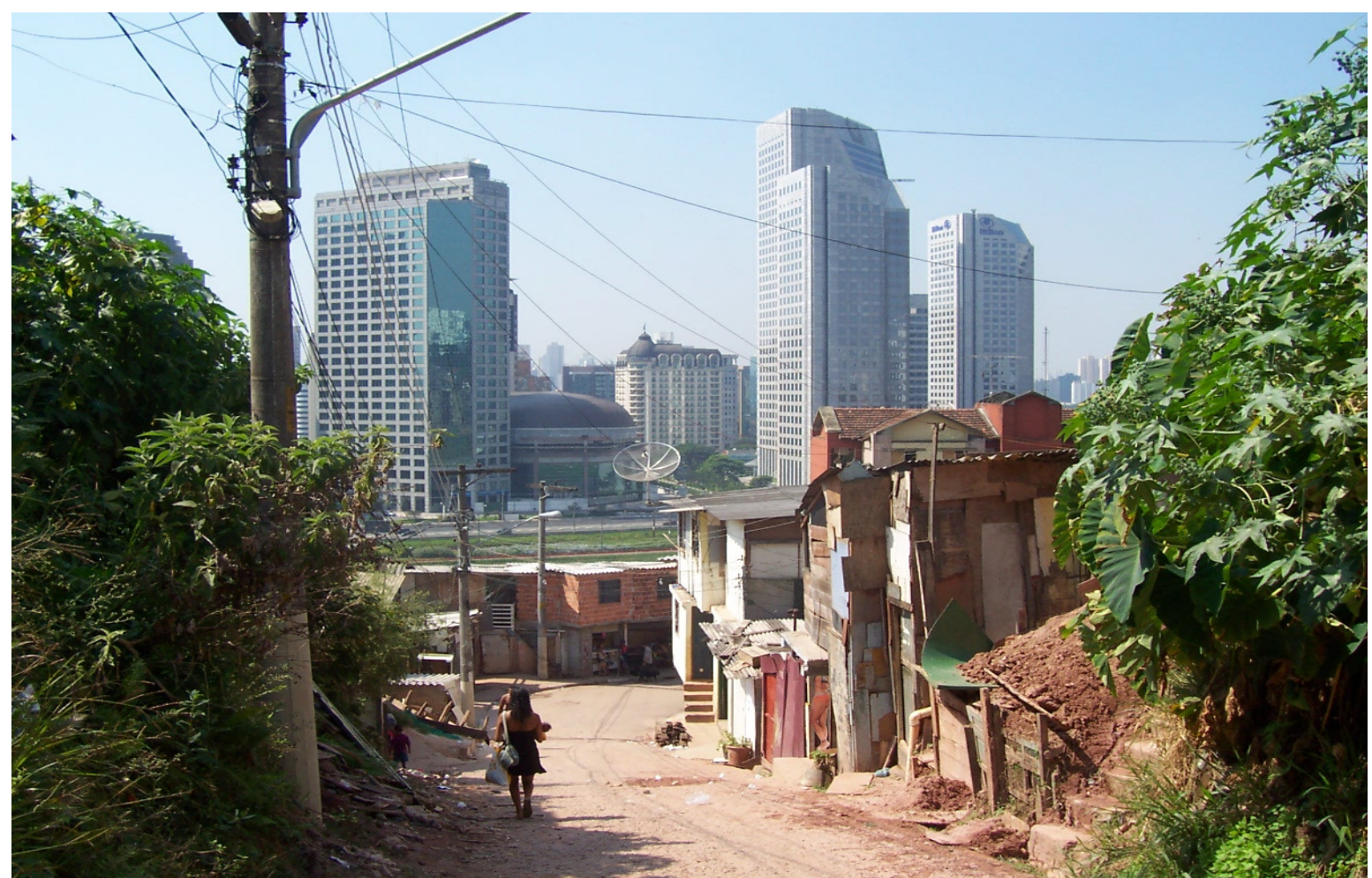

foto 14 do autor 31/03/2007. visão da Berrini a partir da favela da mandioca - Real Parque Morumbi.

As materializações das ações sociais que estão carregadas das intenções em reproduzir o capital recriam espaços dotados de uma nova morfologia, de um novo discurso e:

...Diante de uma metrópole onde as formas mudam e se transformam de modo cada vez mais rápido, os referenciais dos habitantes da metrópole se modificam, produzindo a sensação do desconhecido, do não identificado; aqui as marcas da vida de relações e dos referencias da vida se esfumaçam, ou se perdem para sempre. O estranhamento provocado pelas mudanças no uso do espaço e por uma 
nova organização do tempo na vida cotidiana coloca 0 indivíduo diante de situações mutantes inesperadas. A constante renovação/transformação do espaço urbano por meio das mudanças morfológicas da metrópole produz transformações nos tempos urbanos da vida, nos modos e tempos de apropriação/uso dos espaços públicos... (CARLOS, 2001:32/33).

Daí a necessidade em entender como o econômico e o político se inscrevem espacialmente ao se materializarem, criando novas possibilidades de ações sociais e, por isso, novos poderes.

As ações sociais, políticas e administrativas que comandam a globalização econômica realizam um poder ou formas de dominação/libertação que perpassam pela construção dos novos espaços urbanos nas cidades mundiais, mas, ao contrário da afirmação que se generalizou de que não existem mais fronteiras, de que o capital se mundializou, para SASSEN (1998:44) "a economia mundial jamais foi um acontecimento planetário; sempre teve fronteiras mais ou menos definidas", ou seja, ocorrem entre as áreas centrais e alguns espaços inseridos nos estados nacionais periféricos, de acordo com a necessidade de reprodução do capital, portanto inclui e marginaliza áreas de acordo com as possibilidades que possam oferecer, sejam em termos de recursos naturais, biodiversidade, mão-de-obra, mercado consumidor, serviços e outros.

A competitividade desse processo ligada à reprodução do capital impõe um ritmo cada vez mais rápido para as materializações espaciais, graças aos avanços técnicos. Assim, as formas urbanas são transformadas ou substituídas rapidamente, implantando as inovações nos territórios criando novas ordens. Para Otília Arantes é:

... a partir da desorganização da sociedade administrada do ciclo histórico anterior, cultura e economia parecem estar correndo uma na direção da outra, dando a impressão de que a centralidade da cultura é econômica e a velha centralidade da economia tornou-se cultural, sendo o capitalismo uma forma cultural entre outras rivais. O que faz com que convirjam: participação ativa das cidades nas redes globais via competitividade econômica, obedecendo portanto a todos os requisitos de uma empresa gerida de acordo com os princípios da eficiência máxima, e prestação de serviços 
capaz de devolver aos seus moradores algo como uma sensação de cidadania, sabiamente induzida através de atividades culturais que thes estimulem a criatividade, Ihes aumentem a auto-estima, ou os capacitem do ponto de vista técnico e científico. Tais iniciativas, sejam elas grandes investimentos em equipamentos culturais ou preservação e restauração de algo que é alçado ao status de patrimônio, constituem pois uma dimensão associada à primeira, na condição de isca ou imagem publicitária".(ARANTES, 2002: 47)

A existência ou criação da competitividade espacial, desta maneira "cidade - empresa", nos impõe uma necessidade de maior aproximação, para o entendimento das formas urbanas, principalmente das que resultam ou têm influência no processo de globalização ou expansão da economia mundial.

No Brasil, notadamente, existe a preocupação em disponibilizar as condições para a realização de investimentos do capital internacional, prática estimulada e viabilizada pelo poder público municipal de São Paulo, quando diz que:

A aceleração do processo de globalização, resultante do avanço da tecnologia digital, vem mudando não só a dinâmica dos países e das empresas, mas a geografia internacional. Os principais agentes desta transformação são as empresas, o capital financeiro e as cidades. (D.O.M. 21/10/05: 182).

Colocando a cidade como agente de transformação do espaço, bem como as empresas e o capital financeiro, nos parece que a intenção e o tratamento dado ao espaço, pela gestão municipal, é o de garantir uma vantagem comparativa, ou seja, viabilizar as obras de infra-estrutura que possam atrair investimentos, garantindo o lucro aos investidores através do uso do dinheiro público aplicado nas operações urbanas.

E, para criar o consenso social, reforça-se através dos órgãos oficiais e da mídia, um discurso de que o processo de globalização é natural e inevitável e como necessariamente o capital se espacializa porque precisa se localizar em algum lugar - daí a necessidade da criação ou desdobramento das centralidades - 
com o surgimento de novas atividades ou de suas especializações. Entretanto, sua materialização requer um acordo político, uma legitimação ou uma:

... Animação que se expressa na convergência entre governantes, burocratas e urbanistas em torno de uma espécie de teorema-padrão: que as cidades só se tornarão protagonistas privilegiadas, como a Idade da Informação lhes promete, se, e somente se, forem devidamente dotadas de um Plano Estratégico capaz de gerar respostas imediatas aos desafios da globalização (...), e isto a cada oportunidade (...) de renovação urbana que porventura se apresente na forma de uma possível vantagem comparativa a ser criada... (ARANTES,2002: 13).

Deste modo boa parte das estratégias espaciais de transformação da cidade se pautam em modelos, como o de Barcelona, que serve para o debate de como devemos proceder em relação aos projetos de urbanização, como podemos ver na divulgação realizada no Diário Oficial da Cidade de São Paulo em 11/02/06.

\section{Aula São Paulo promove troca de experiências entre metrópoles}
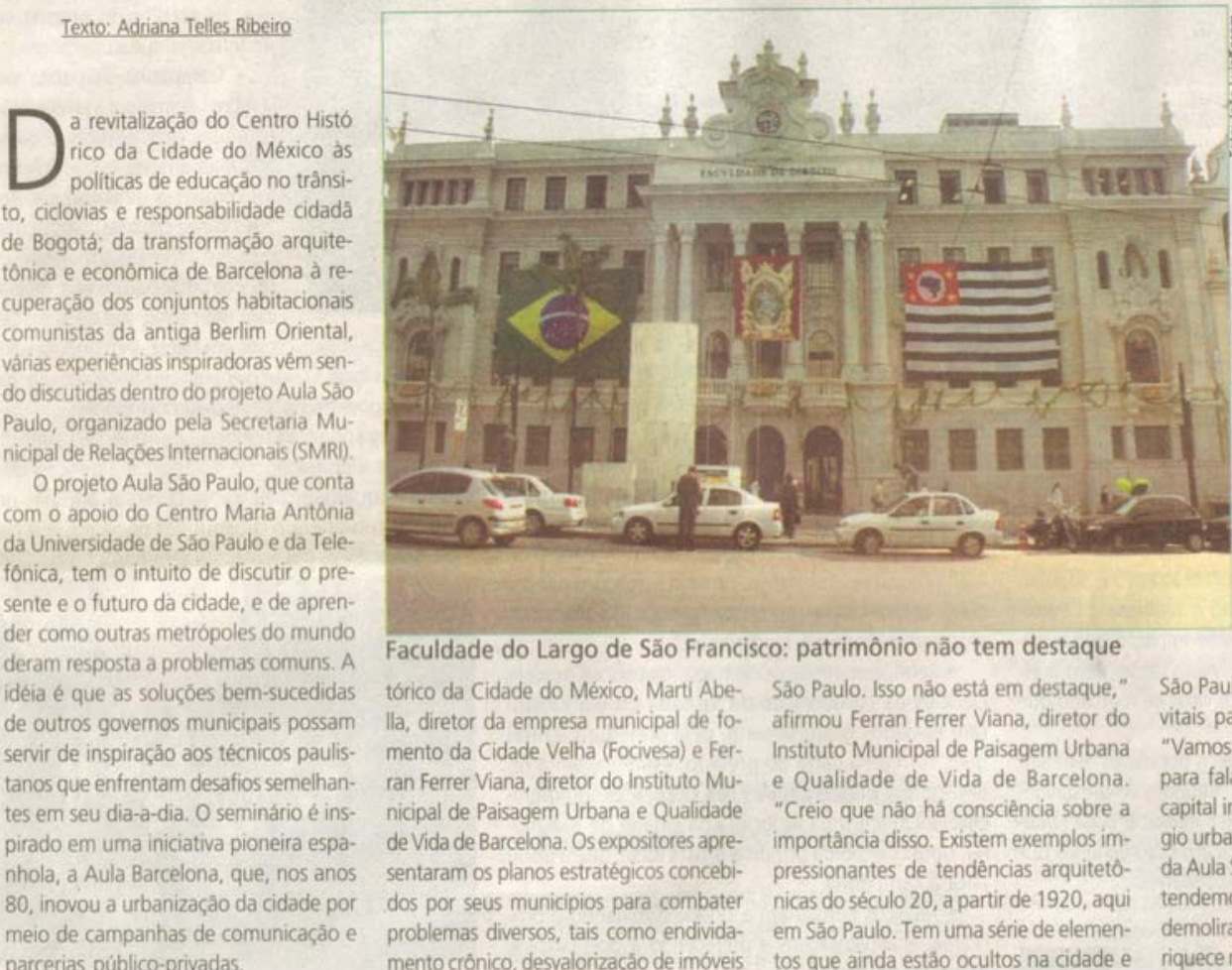

é apaixonante, além do mais por ser uma das maiores cidades do mundo. E uma referência continua; então a essa referência só falta um adorno, a história e os elementos que as pessoas possam identificar como icones."

As palestras do seminá rio săo direcionadas aos funcionários da prefeitura, bem como abertas ao público no Centro Maria Antônia, da Universidade de Săo Paulo. Também săo realizadas reuniôes individuais com secretários e entrevistas com jornalistas.

Para o ano de 2006

Faculdade do Largo de Săo Francisco: patrimônio não tem destaque tórico da Cidade do México, Marti Abe- Săo Paulo. Isso náo está em destaque, lla, diretor da empresa municipal de fo- afirmou Ferran Ferrer Viana, diretor do mento da Cidade Velha (Focivesa) e Fer- Instituto Municipal de Paisagem Urbana ran Ferrer Viana, diretor do Instituto Mu- e Qualidade de Vida de Barcelona. nicipal de Paisagem Urbana e Qualidade "Creio que náo há consciência sobre a de Vida de Barcelona. Os expositores apre- importância disso. Existem exemplos imsentaram os planos estratégicos concebi- pressionantes de tendências arquitetôdos por seus municipios para combater nicas do século 20, a partir de 1920, aqui problemas diversos, tais como endivida- em Săo Paulo. Tem uma série de elemenmento crônico, desvalorizaçáo de imóveis tos que ainda estáo ocultos na cidade e além dos seminários confirmados (veja agenda) a Aula São Paulo planeja palestras com temas vitais para a problemática da cidade. "Vamos trazer especialistas de Londres para falar da revolução do trânsito na capital inglesa e como funciona o pedágio urbano", conta o coordenador geral da Aula Sáo Paulo, Raul Juste Lores. "Pretendemos trazer os técnicos de Seul, que demoliram o Minhocão deles. Você enriquece muito nossas discussóes locais ao

Fonte: Diário Oficial da Cidade de São Paulo - 11/02/2006. 
Esse acordo, ou essa animação que acaba "justificando" certos projetos mediante a opinião pública, aparentemente tem sido consensual na administração de São Paulo em várias gestões do município e vem se confirmando com a gestão do Prefeito José Serra ${ }^{18}$ que, a partir do Plano Plurianual (2006/2008) demonstra a intenção de nos tornar protagonistas do processo de globalização, porque:

A crescente internacionalização dos fluxos de bens, serviços e informações dão origem à formação de uma rede mundial de metrópoles, onde são geradas e por onde transitam as decisões financeiras, mercadológicas e tecnológicas capazes de moldar os destinos da economia mundial. Os centros urbanos situados no topo da hierarquia do sistema urbano nacional são denominados Cidades Globais, que atuam como foco de irradiação das decisões tomadas em escala planetária para as demais cidades do sistema.

Ao lado delas existem as Cidades Mundiais. Nestas, as vantagens comparativas regionais e metropolitanas, derivadas das atividades exportadoras, devem constituir-se no principal foco de dinamismo para as grandes metrópoles, em especial as atividades ligadas à indústria intensiva em tecnologia e aos serviços típicos de cidades mundiais, tais como telemática, pesquisa e desenvolvimento (P\&D), consultoria de negócios, gestão empresarial e financeira e serviços de transportes internacionais. São Paulo já pode ser considerada dentro desta categoria. Mas é preciso consolidar e avançar o papel de São Paulo como Cidade Global (D.O.M. 21/10/05: 182)

Ao nos inserir no contexto de cidade mundial que deverá avançar à condição de cidade global, o discurso acima não deixa dúvidas quanto à posição da gestão municipal em relação ao tratamento que deve ser dispensado ao espaço metropolitano, "é preciso consolidar e avançar o papel de São Paulo como Cidade Global”, ou seja, a cidade-mercadoria está à disposição no mercado e precisamos nos esforçar para Ihe agregar "valor", tornando-a uma mercadoria competitiva. Nesse sentido podemos ver "o futuro repetindo o passado", na medida em que:

O mundo oferece as possibilidades: e o lugar oferece as ocasiões. Não se trata aqui de um 'exército de reserva' de

\footnotetext{
${ }^{18}$ Em abril de 2006 o então prefeito da cidade de São Paulo José Serra se licencia para poder concorrer ao cargo de governador de Estado.
} 
lugares, senão da produção raciocinada de um espaço, no qual cada fração do território é chamada a revestir características específicas em função dos atores hegemônicos, cuja eficácia depende doravante de uma produtividade espacial, fruto de um ordenamento intencional e específico. (SANTOS, 1998:50).

Sem a anuência do poder local e sua disposição em participar não haveria as ocasiões, e em nosso caso, as ocasiões estão disponibilizadas de forma muito aberta, de forma bem explícita no Plano Plurianual como segue:

A capacidade de oferecer uma eficiente infra-estrutura de telecomunicações e demonstrar capacidade de administrar com competência para enfrentar o conflito sócio-espacial é, dessa forma, decisiva. Torna-se fundamental, assim, instalar, por exemplo, uma eficiente rede de telefonia de fibras óticas; centros de excelência em tratamentos de saúde (como os oferecidos pelo Incor e os hospitais Albert Einstein e Sírio Libanês), centros de pesquisa científica de ponta, além de atrativos culturais, como um rico museu e uma orquestra sinfônica de nível internacional. Também é fundamental criar condições para enfrentar as questões ambientais decorrentes da ocupação ilegal dos mananciais, encaminhar e resolver as questões relacionadas aos moradores de rua, aos cortiços, à criação de espaços públicos adequados, enfim, tudo que confere a uma cidade ou metrópole a possibilidade de integrar a rede das cidades mundiais". (D.O.M. 21/10/05: 183).

Como podemos verificar, para a gestão municipal, não existe outra forma de desenvolvimento e organização urbana do que a integração com o capital hegemônico mundial e local. Nas chamadas operações urbanas Centro e Água Espraiada se percebe a presença forte da valorização dos chamados elementos culturais, porque sem os "atrativos culturais, como um rico museu e uma orquestra sinfônica de nível internacional”, bem como sem a Praça da Sé, o Teatro Municipal, o Mercado Municipal, entre outros, a produção de um marco arquitetônico moderno no sudoeste da cidade, no caso a Ponte Estaiada, junto ao centro Berrini, pode contribuir na criação do que se chama de "moderno", mas não é suficiente para tornar São Paulo uma cidade mundial.

A efetivação do processo descrito acima ocorre através das várias "parcerias público-privadas" e o que podemos ver é que: 
A dinâmica dos espaços da globalização supõe adaptação permanente das formas e das normas. As formas geográficas (...), só autorizam essa otimização ao preço do estabelecimento e aplicação de normas jurídicas, financeiras e outras, adaptadas às necessidades do mercado. Essas normas são criadas em diversos níveis geográficos e políticos, mas, dada a competitividade mundial, as normas globais, induzidas por organismos supranacionais e pelo mercado, tendem a configurar as outras. (SANTOS, 1998:55).

A adequação das normas possibilitou e está permitindo o desdobramento da centralidade São Paulo para a Berrini e mesmo que se destaque, no texto do Plano Plurianual, a questão social como emergente; uma das justificativas apontadas nesse Plano atende principalmente aos interesses do capital financeiro em parcerias entre o capital local, o global, a iniciativa privada e o poder público deixando de lado, nas ações realizadas, as questões sociais existentes na cidade.

Aqui percebemos outro elemento que requer a ligação entre o centro Berrini e o Centro, à medida que a gestão municipal se localiza no Centro como também a Bolsa de Valores, a Bolsa de Mercadorias e Futuros, a maioria dos Fóruns e escritórios de advocacia; exigindo para a realização dos "negócios" uma ligação constante entre os centros. Como é parte de um processo desigual, seletivo, os altos executivos e empresários, assim como os políticos dispõem de meios de transporte mais modernos, como o uso de helicópteros, que minimizam o papel da distância e do trânsito da cidade.

E, em alguns casos, como o da Rede Globo, se produz todas as condições no próprio local, ou seja, se apropriou de um terreno de dimensões vantajosas que permitiu construir desde escritórios a estúdios, "Com 12 andares e 3 subsolos, o novo edifício se junta aos dois outros núcleos da Rede Globo no bairro do Brooklin: o de jornalismo e o de produção" (G1, SPTV 26/04/07) e se posiciona junto a duas vias importantes na cidade, uma de fácil acesso ao aeroporto de Congonhas, antiga Água Espraiada e atual Jornalista Roberto Marinho e a outra, a Marginal do Rio Pinheiros, importante marco da cidade e referência para noticiários sobre o trânsito e o cotidiano da cidade. 


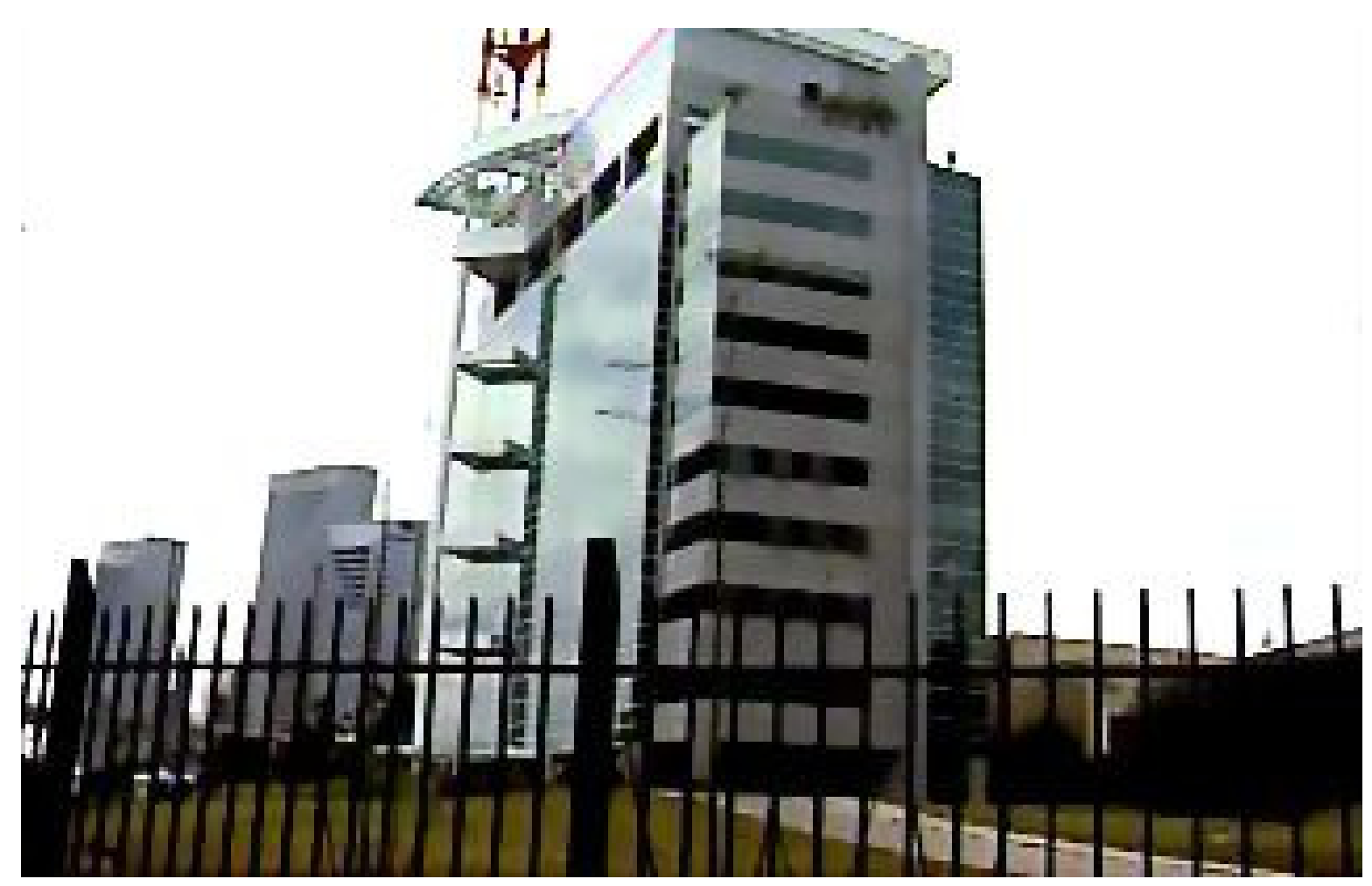

imagem retirada da www.g1.globo.com - reportagem sobre a inauguração do novo prédio da Rede Globo dia 26/04/07 junto ao centro Berrini.

Como falamos de um processo contraditório e desigual, podemos perceber que há, nos discursos oficiais, a idéia de que as centralidades, em escala nacional, competem e se articulam no processo de globalização econômica. Quando da inauguração do novo prédio da Rede Globo em São Paulo, no centro Berrini, a então, atual gestão municipal, na voz de seu prefeito declarou que:

"São Paulo sempre teve um pouco de ciúme do Rio de Janeiro em função de a Rede Globo ter nascido no Rio", disse o prefeito de São Paulo, Gilberto Kassab. Segundo ele, o prédio simboliza "a presença crescente da Globo na nossa cidade". (G1, com informações do SPTV, 26/04/07).

De fato, a presença da Rede Globo somente foi possível com o auxílio municipal e estadual permitindo a essa emissora que ocupasse boa parte do terreno que antes era ocupado pelas famílias de baixa renda que formavam a favela do Jardim Edith, além da mudança do nome da avenida do entorno para Jornalista Roberto Marinho bem como a criação de uma nova rua junto à Avenida das Nações Unidas, Rua Evandro Carlos de Andrade, onde fica a nova portaria da emissora. "O nome da rua é uma homenagem ao ex-diretor de jornalismo da 
empresa"(G1, SPTV, 26/04/07), o que aponta para uma participação crescente da empresa em São Paulo, como podemos perceber, também, na fala do atual gestor estadual.

O governador de São Paulo, José Serra, também citou ironicamente a rivalidade entre São Paulo e Rio ao apontar as parcerias do governo do estado com a TV Globo, como o Projeto Pomar, o Museu da Língua Portuguesa e o Museu do Futebol. "Que servirá de modelo para o Museu de Futebol do Rio", brincou Serra, provocando riso entre os presentes. Após discursar, o governador descerrou a placa do edifício ao lado de Roberto Irineu Marinho. (G1, com informações do SPTV, 26/04/07).

As parcerias públicas-privadas parecem ser a marca da atual produção urbana em São Paulo, com benefício concreto para as partes privadas, hegemônicas, que, como vimos, fazem uso do espaço e de sua infra-estrutura de forma a obter uma vantagem comparativa.

Resta saber como fica a população que mora no espaço público dessa região, espaço que, de acordo com os documentos oficiais (Plano Diretor), deveria estar sendo reurbanizado, atendendo à população de baixa renda que aí vive, ou, como veremos mais adiante, os agentes não-hegemônicos. Essas pessoas vivem em favelas, áreas de risco, espaços que, no senso comum, são muito presentes no que vem sendo denominado como periferia. Mas como os espaços dos considerados agentes não hegemônicos, que eram ou faziam parte de áreas periféricas, passam a ser, também, o mesmo espaço dos agentes hegemônicos e da centralidade econômica?

Precisamos, agora, abrir a discussão do que, para alguns autores, se define por periferia e, para LANGENBUCH:

(...) parte da cidade localizada em suas bordas (...) faixa da cidade que antecede os subúrbios. No Brasil, o termo vem sendo utilizado com forte conotação social, reportando-se quase sempre a porções de qualquer aglomeração urbana, não necessariamente grande, localizada via de regra em porção próxima aos limites externos da área edificada, onde predomina a ocupação residencial pelas camadas mais pobres da população, estabelecida de modo bastante precário (2001:89). 
Considerando que o que caracteriza a periferia espacialmente é sua posição nas bordas da cidade, um espaço que não faz parte da área edificada e também não é subúrbio ${ }^{19}$ e que, socialmente, é o espaço onde predomina as camadas mais pobres da população, como poderíamos denominar as áreas de favela e de risco ocupadas na região da Berrini? Elas poderiam representar ou possibilitar a existência de um conflito espacial e social?

Acreditamos que sim, quando a centralidade econômica de São Paulo, por meio do processo urbano de produção / reprodução do seu espaço, foi sendo desdobrada e alcançou espaços já existentes como a favela do Jardim Edith. Assim, a Berrini como um desdobramento do Terciário Moderno, agora ocupa também espaços que faziam parte da favela do Jardim Edith (que era considerada periferia) que parcialmente foi removida, permanecendo um resíduo significativo junto à Avenida Jornalista Roberto Marinho e a Rua Charles Coulomb. Veremos adiante que a favela da Mandioca no Real Parque Morumbi também chamada por muitos de periferia, sofre transformações espaciais significativas provocadas pelo desdobramento da centralidade.

Continua o questionamento: seriam as favelas, presentes na região da Berrini, periferias? Para Nabil Bonduki, a periferia está ligada à falta de infraestrutura, em suas palavras:

questionava a idéia de periferia como um local geográfico, a franja periurbana. Loteamento periférico para nós era loteamento precário, sem infra-estrutura (2001:93).

Sem desconsiderar o espaço que havia entre o Centro e a periferia e, percebendo, que o desdobramento da centralidade está alcançando e englobando alguns dos espaços periféricos e de "certa forma" produzindo uma infra-estrutura, é possível afirmar que a periferia foi urbanizada?

Para José de Souza Martins:

\footnotetext{
19 José de Souza Martins (2001:78) "O conceito de subúrbio (...). Foi e tem sido muito mais a designação de um modo de vida peculiar especificamente referido às regiões de confim entre a cidade e o campo (...) No subúrbio, mesmo na fase já alcançada pela industrialização e pelos loteamentos de terrenos para moradias operárias, os lotes eram grandes, as casas tinham espaço para o grande quintal, um remanescente do rural que permanecia no urbano: fruteiras, hortas, galinheiros, fornos de pão e broa, jardins, muitas flores e um certo suave perfume suburbano".
} 
O problema da periferia é o problema do tumulto da ocupação, o da urbanização patológica, da exclusão, da falta de efetivas alternativas de inserção no mundo urbano (...) O problema da periferia é o do desenvolvimento econômico.(2001:79).

Sendo problema do desenvolvimento econômico, a periferia pode ser caracterizada como a não possibilidade de acesso e ao uso da cidade, é a negação do urbano que explode, se desdobra, chega na periferia, a engloba transformando os espaços, mas não a inclui ou inclui marginalmente ou perversamente.

E, os não hegemônicos como participam desse processo?

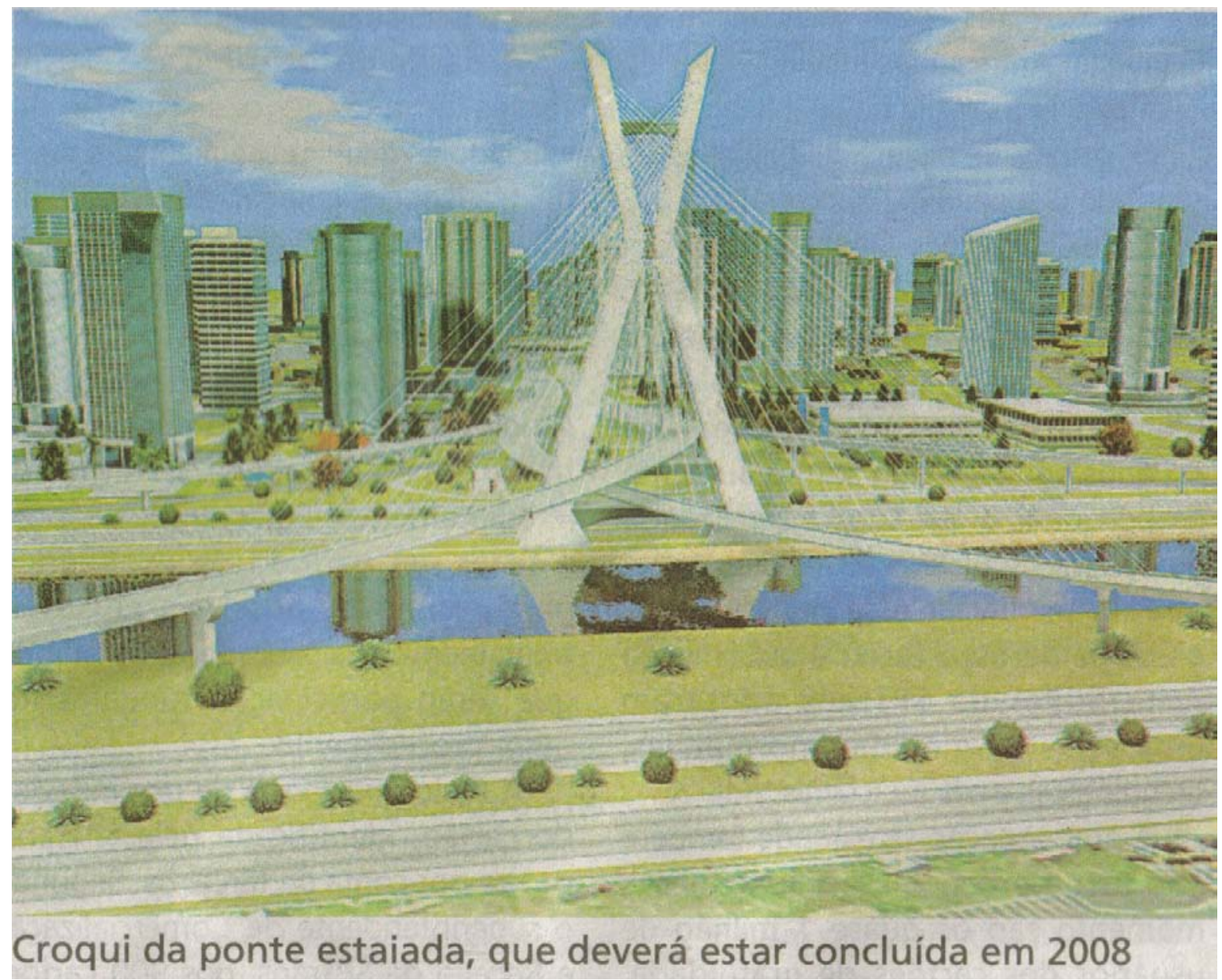

Fonte: Diário Oficial da Cidade - 17/03/2007. 


\section{Os agentes não hegemônicos: resistência ou inserção na mesma lógica de produção?}

"Nos barracos da cidade ninguém mais tem ilusão

no poder da autoridade

De tomar a decisão

E o poder da autoridade

Se pode, não faz questão

Se faz questão, não consegue

Enfrentar o tubarão"

Gilberto Gil

A noção de autoridade que Gilberto Gil revela nos versos acima, olhando a partir dos barracos da cidade, em que os ocupantes / detentores do poder tomam decisões parciais, em favor de alguns, no caso dos hegemônicos, não fazendo questão ou não tendo a preocupação social com as condições de vida dos demais, os que chamamos aqui de não hegemônicos. Ou quando faz questão de procurar atender à parcela da população com as maiores carências, não consegue realizar os devidos encaminhamentos porque esbarra nos conflitos de interesses em que o poder dos hegemônicos se faz priorizar.

Expomos, com a ajuda de um modo de ver poético, que na produção do espaço na cidade se realiza e se concretiza a luta de classes, simbolicamente representada pelos "barracos na cidade", local de moradia dos não hegemônicos, e pelo "tubarão" simbolizando o poder e a astúcia dos hegemônicos nos versos de Gilberto Gil.

Nesse processo que reproduz a desigual luta de classes, a cidade vai sendo produzida, a sua centralidade sendo desdobrada de modo a alcançar a periferia. Como ficam os não hegemônicos, resistem ou tentam se inserir na mesma lógica de produção?

É com a visão de quem busca, agora, se posicionar olhando a partir dos barracos da cidade, junto aos que aí vivem, no Real Parque Morumbi mapa 
$\mathrm{n}^{\circ} 9$, favela da Mandioca ${ }^{20}$. Nas fotos 15 e 16, seus moradores, que consideramos como sendo os agentes não hegemônicos aos quais estamos nos referindo, são as pessoas de baixo poder econômico que vivem, em sua maioria, com apenas um salário mínimo, outros, sem salário nenhum; morando em barracos de madeira e em casas de alvenaria fruto da autoconstrução ou, no caso de alguns, nos conjuntos Cingapura ${ }^{21}$. Uma periferia imediata, uma vez que a centralidade ao se desdobrar alcançou esses lugares. Assim, entre o centro Berrini e os conjuntos habitacionais para as classes média e alta do Real Parque Morumbi, encontramos, nos interstícios, áreas como a favela da Mandioca.

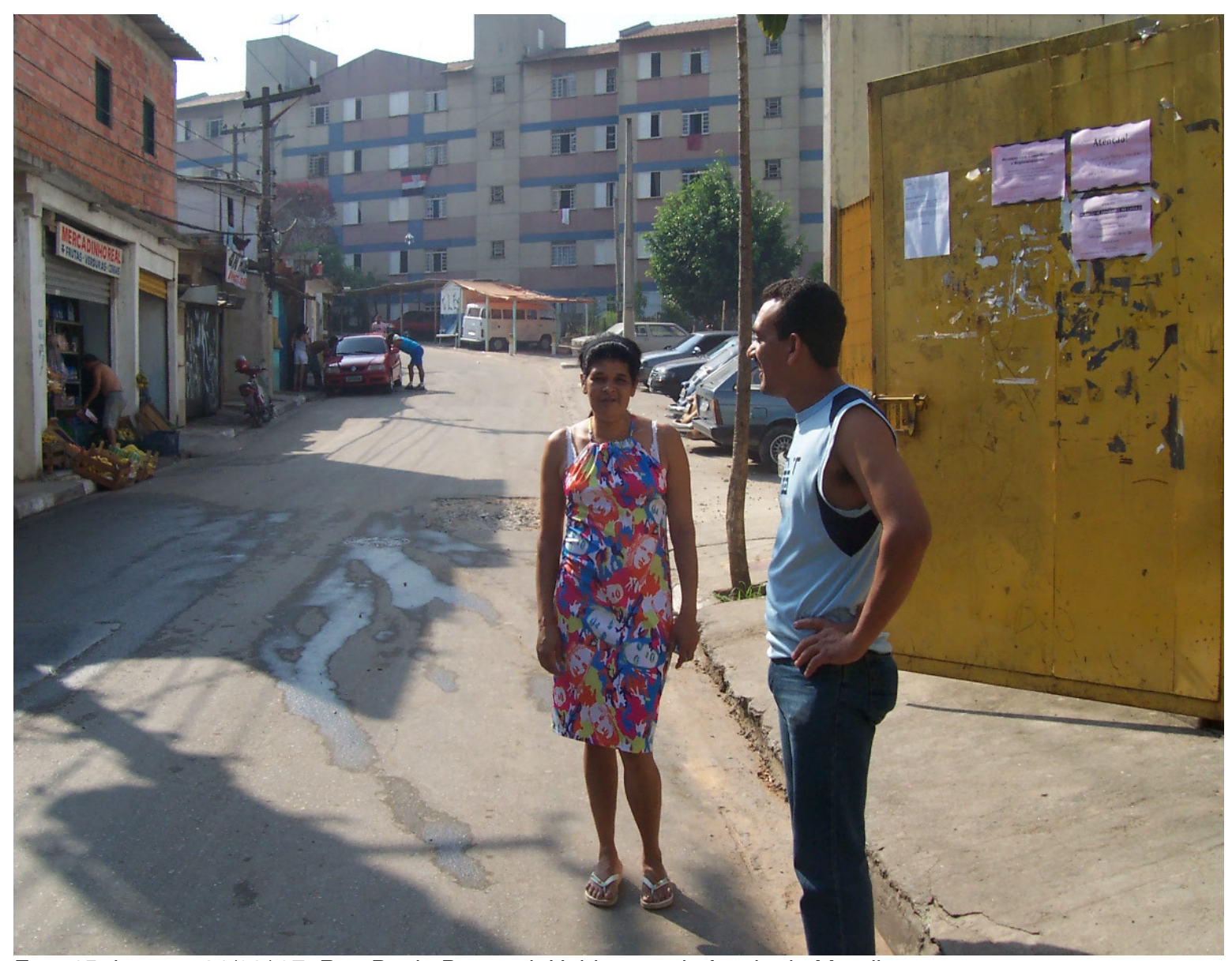

Foto 15 do autor 31/03/ 07. Rua Paulo Bourroul. Habitantes da favela da Mandioca.

\footnotetext{
${ }^{20}$ Segundo depoimento dado a mim por Dona Celene, antiga moradora, no local onde hoje se concentra a maior parte da favela, era um morro ocupado por plantações de mandioca, daí o nome da favela que, para muitos, hoje é conhecida apenas como favela do Real Parque. (14/07/2006)

${ }^{21}$ Habitações populares, conjuntos de apartamentos, construídas durante a gestão municipal de Paulo Maluf 1993/1997, em um programa de verticalização de favelas.
} 
Mapa 9.

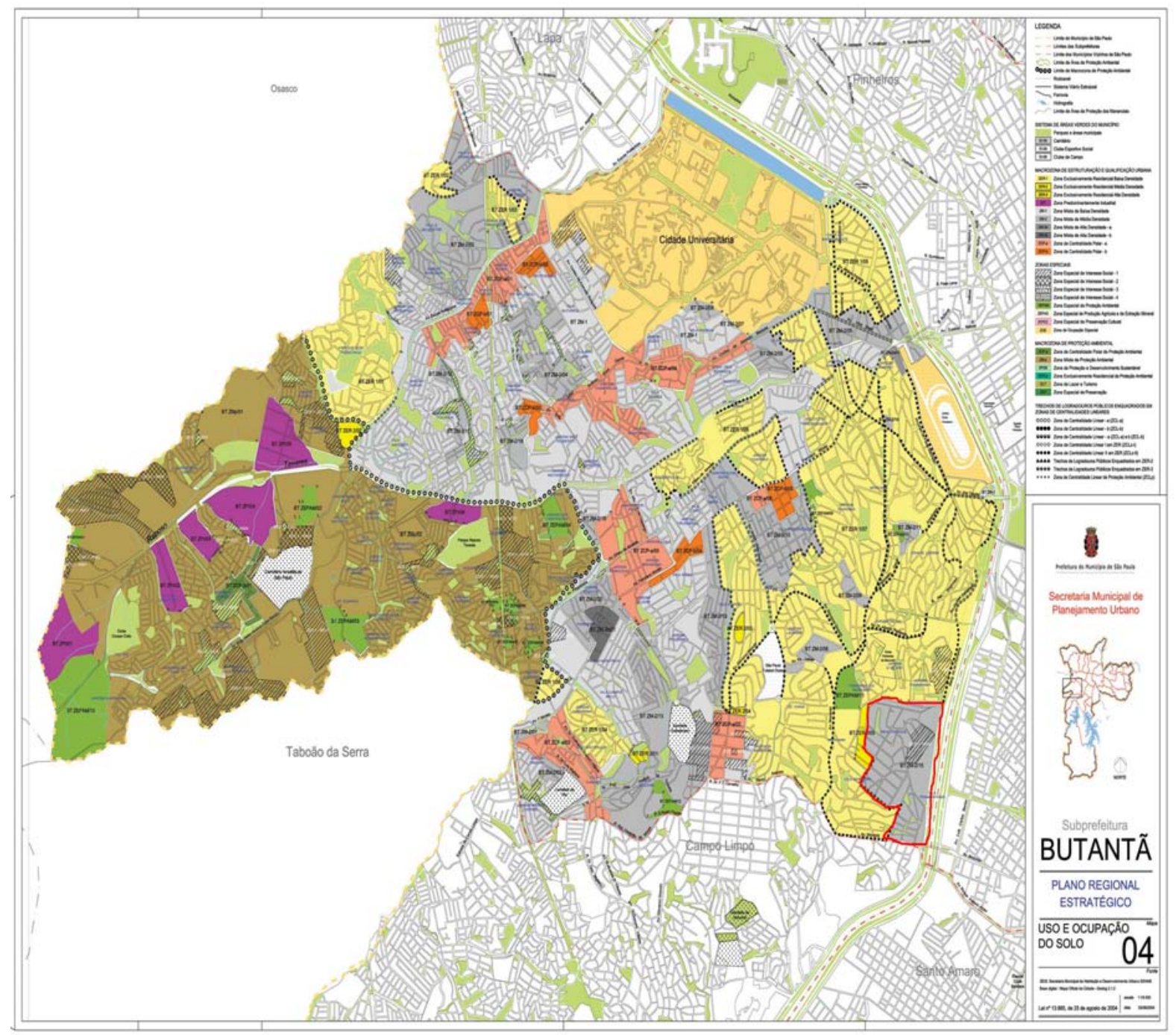




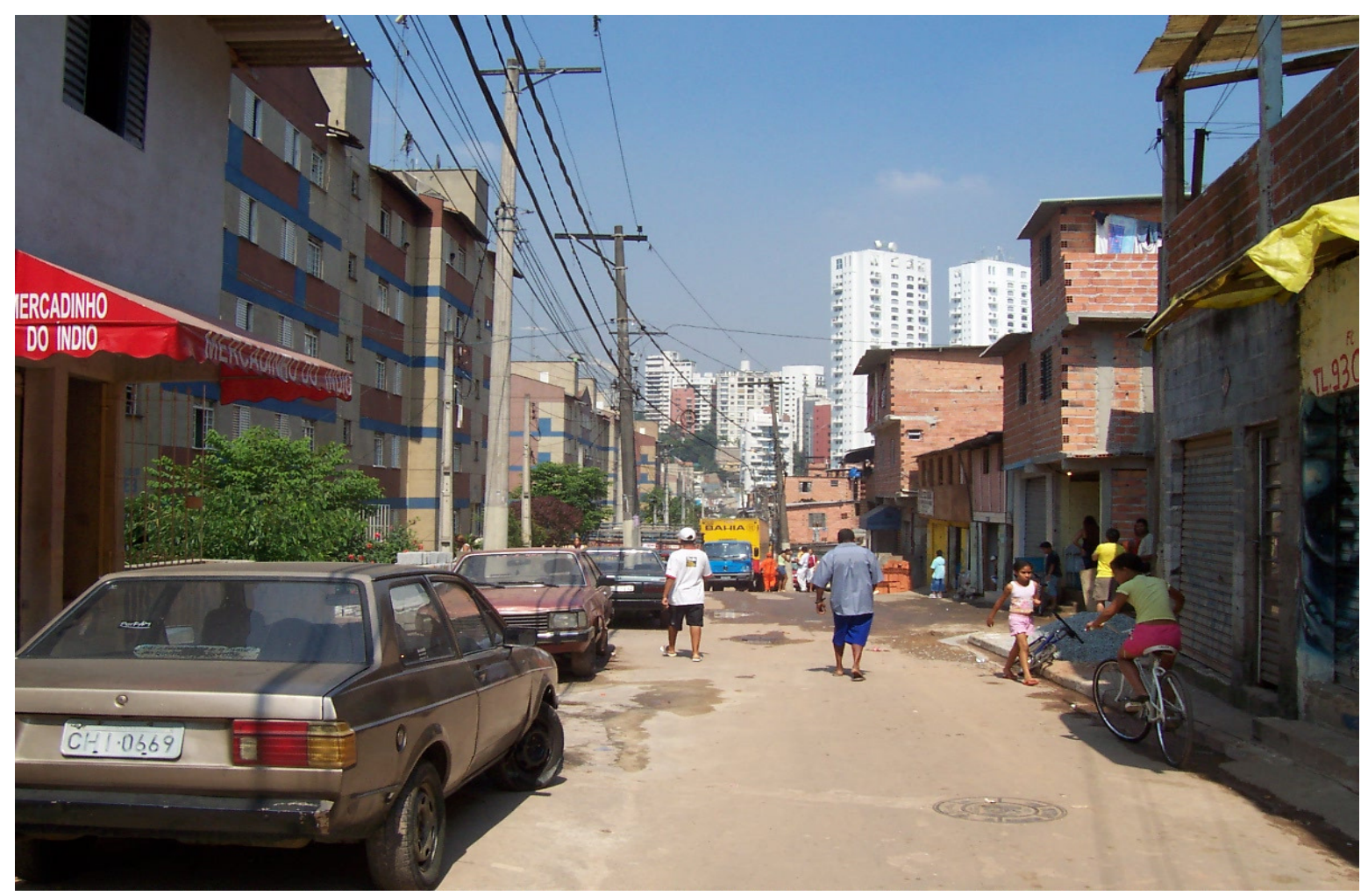

Foto 16 - do autor 31/03/07. Rua Paulo Bourroul - moradores e trabalhadores.

Na primeira foto, $\mathrm{n}^{\circ} 15$, em primeiro plano está o senhor Wanderley Ribeiro e ao seu lado Dona Maria Aparecida, trabalhadores e moradores na favela da Mandioca. $\mathrm{Na}$ foto ao lado, $\mathrm{n}^{\circ} 16$, moradores em seu dia-a-dia na vida que acontece no Real Parque (bicicleta, mercadinho do índio, Casas Bahia, etc.).

Será que essas pessoas participam da expansão da centralidade de São Paulo e da globalização? A expansão da centralidade interfere diretamente em suas vidas? Interfere no lugar que habitam? Resistem à lógica de produção hegemônica do capital ou tentam reproduzir a mesma lógica?

Começamos a adentrar na favela da Mandioca pela Rua Paulo Bourroul conforme localização abaixo, e defronte à Escola Municipal de Educação Infantil Pero Neto e o Projeto Casulo ${ }^{22}$ nos deparamos com uma Lan House - internet e jogos - próxima a um conjunto de casas de alvenaria e de remanescentes barracos de madeira de acordo com a foto $n^{\circ} 17$. O que a Lan House representa

\footnotetext{
${ }^{22}$ A escola pública foi construída por um pool de empresas ligadas ao ICE - Instituto de Cidadania Empresarial, que também utilizou o mesmo terreno e construiu de forma contígua à escola pública um equipamento privado que é o prédio do Projeto Casulo que explicaremos adiante.
} 
neste lugar? É a conexão com o quê? Ou a proximidade com o quê? Ou seria uma das facetas tecnológicas que invadem a vida moderna urbana?

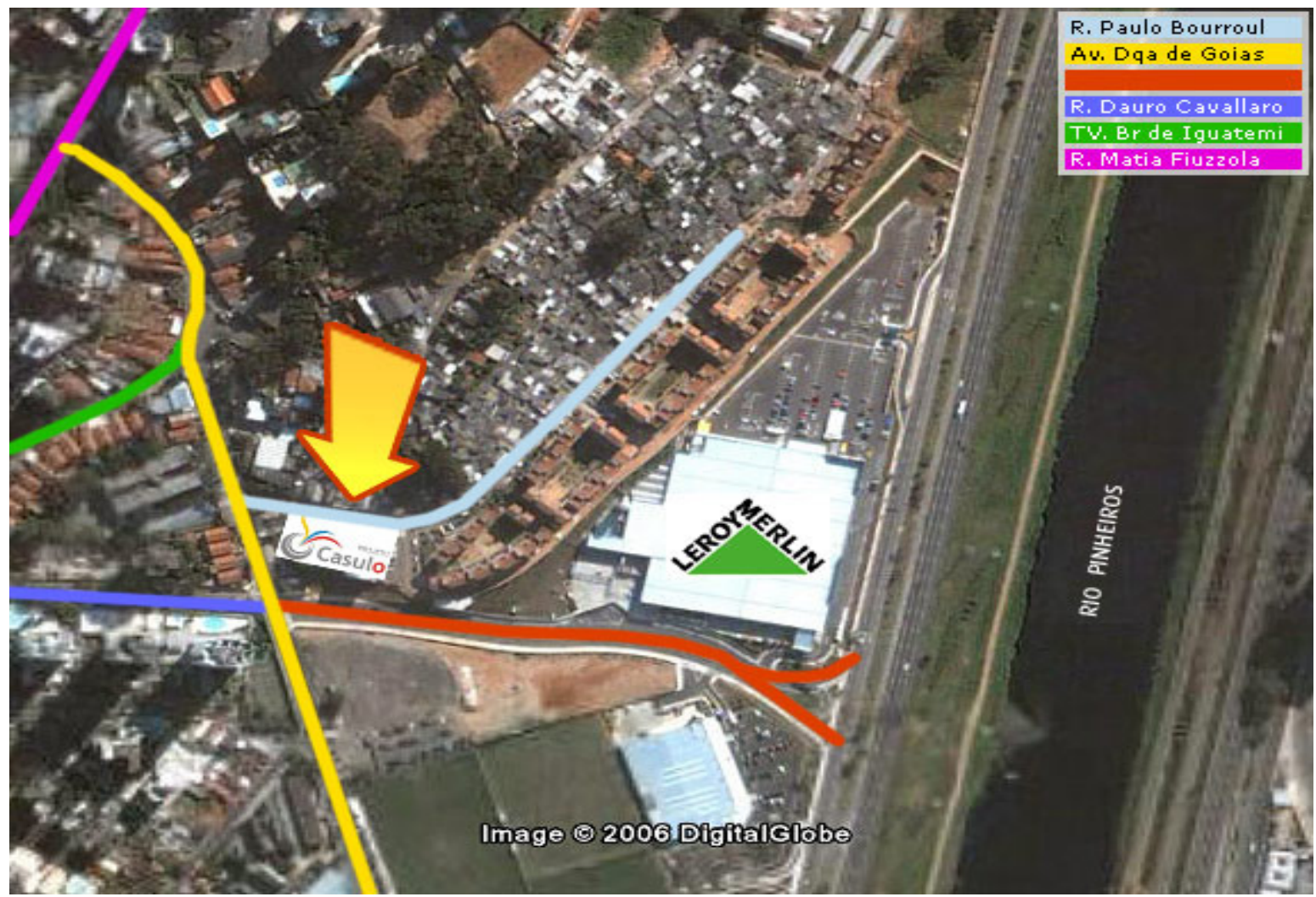

Mapa 10 fonte site www.projetocasulo.org.br localização Projeto Casulo, EMEI Pero Neto e Favela da Mandioca.

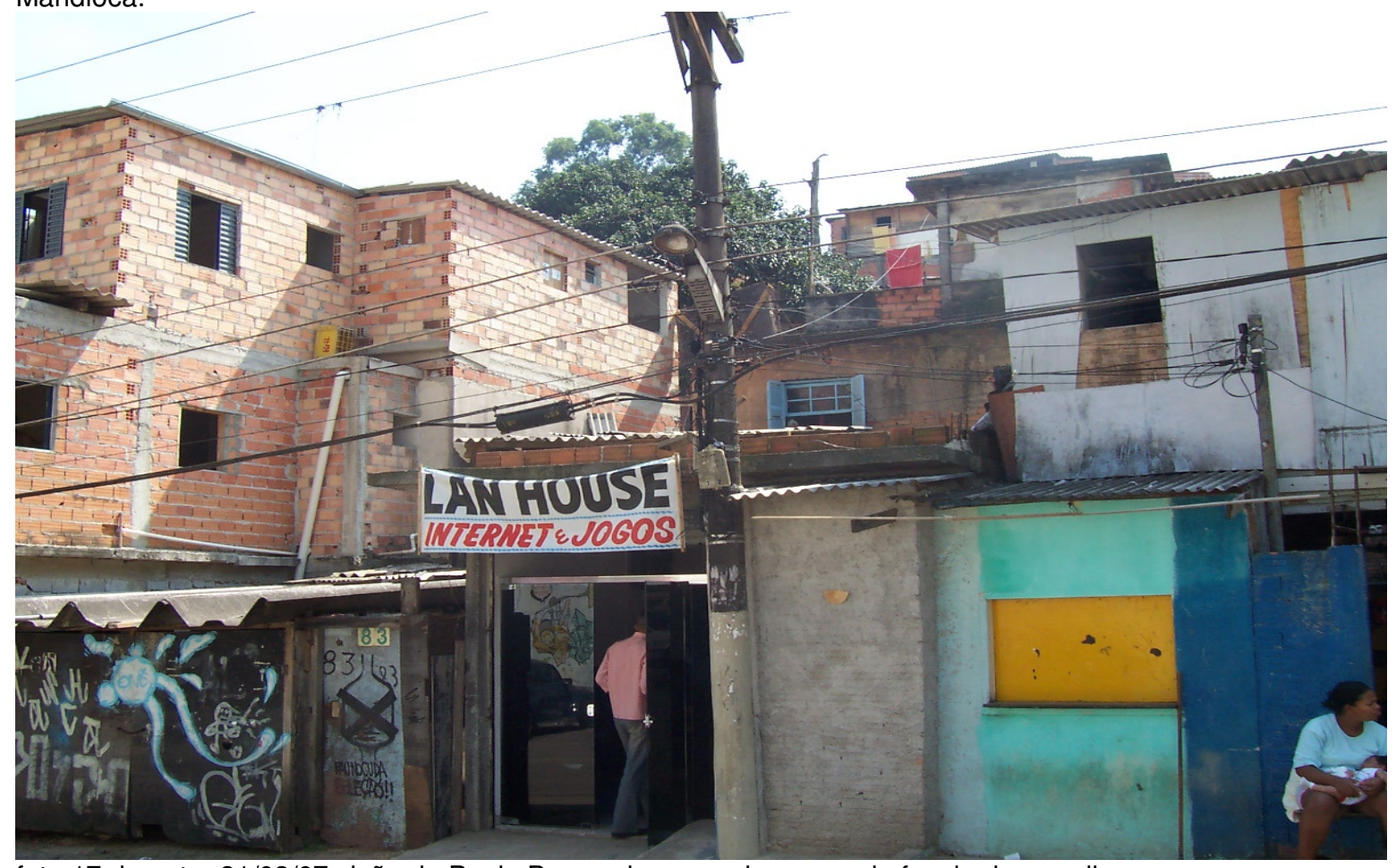

foto 17 do autor 31/03/07 visão da Paulo Bourroul casas e barracos da favela da mandioca. 
Sendo parte da sociedade de consumo e uma faceta tecnológica, precisamos lembrar que para Lefebvre a periferia imediata está "ao redor das 'barreiras', das portas" (2001:15). Neste sentido, o que significa estar próximo, estar "conectado"? Será que significa poder, apesar dos baixos recursos, consumir alguns bens, símbolos de "modernidade"?

Como vimos anteriormente, a periferia que tinha como uma de suas características fundamentais a localização, um espaço distante ao Centro e sem infra-estrutura básica, foi alcançada pelo desdobramento da centralidade econômica e para Guy Debord "esta sociedade que suprime a distância geográfica recolhe interiormente a distância, como separação espetacular" (2006:112). Nesse sentido se levanta a questão: deixou de ser periferia? De forma semelhante, o acesso à internet e a canais de televisão por meio de antenas parabólicas, a possibilidade de comprar celulares de última geração, significa fazer parte do mundo globalizado?

Não discutiremos nesta pesquisa a existência ou não de uma periferia virtual ou tecnológica, mas utilizamos a idéia de conexão para discutir a questão da globalização neste lugar.

Percebemos que existe o desejo e a vontade de fazer parte do "mundo globalizado" de acordo com a fala abaixo, de um dos moradores, em relação ao Projeto Casulo $^{23}$ que oferece cursos de dança, pintura, música, teatro, mediação de leitura e de informática para adolescentes da favela, ou como veiculado em seu site - www.projetocasulo.org.br - "atender jovens entre 12 a 24 anos, em situação de vulnerabilidade social".

Eu acho que eles (Projeto Casulo) deveriam investir mais no ensino profissionalizante porque você sabe que dança, teatro essas coisa dentro de cem, de mil, às vezes dois se destaca, mas a computação que eles dão aqui é muito básico, tão básico que um curso dura dois meses, enquanto, a criança tem uma hora acho que nem uma hora e meia de aula, entendeu, que deveria ter no mínimo, para uma criança ter um bom básico assim pra ela tá mais ou

\footnotetext{
${ }^{23}$ O Projeto Casulo é um programa que visa o desenvolvimento comunitário do Real Parque e do Jardim Panorama, zona sudoeste da cidade de São Paulo. Foi fundado em abril de 2003 e é uma iniciativa do Instituto de Cidadania Empresarial (ICE), em parceria com a Prefeitura de São Paulo e vinte empresas, fundações e institutos. O prédio ocupa o mesmo espaço da EMEI Pero Neto.
} 
menos interada tem que ter no mínimo três horas de aula (Wanderley Ribeiro Neves 14/03/07).

A fala do Sr. Wanderley demonstra uma preocupação de inserção social com cursos profissionalizantes que respondam à necessidade de "empregabilidade imediata", já que para muitos, no senso comum, o problema do desemprego e dos baixos salários está exclusivamente ligado à falta de qualificação profissional e não a uma nova forma de produção, que é mundial e que visa maiores lucros, competitividade, transformando e flexibilizando as relações de trabalho. Haja vista tudo se resumir à falta de qualificação, uma das medidas para sanar essa deficiência estaria na profissionalização, no acesso a um curso de informática que, de acordo com sua visão, é fundamental, ou melhor, é básico. Os demais cursos ficam para segundo plano, à proporção que "dentro de cem, de mil, às vezes dois se destaca", o que demonstra a forte influência da idéia de que basta estarem "plugados, conectados" e "qualificados" que terão mais oportunidades de emprego no "mundo globalizado".

Some-se a essa experiência, o consenso produzido por documentos como o Diário Oficial do Município de São Paulo e também pela mídia de que a globalização é inevitável e de que todos devem fazer parte. A imagem que vêem de suas janelas, fotos 18 e 19, quando olham para a Berrini, permite sentir a "modernidade" se aproximando. De fato, está criado no imaginário dos moradores, do Real Parque e na favela da Mandioca, a necessidade de cursos de informática e isto justifica, "de certa forma", a existência de uma Lan House em meio aos barracos. 


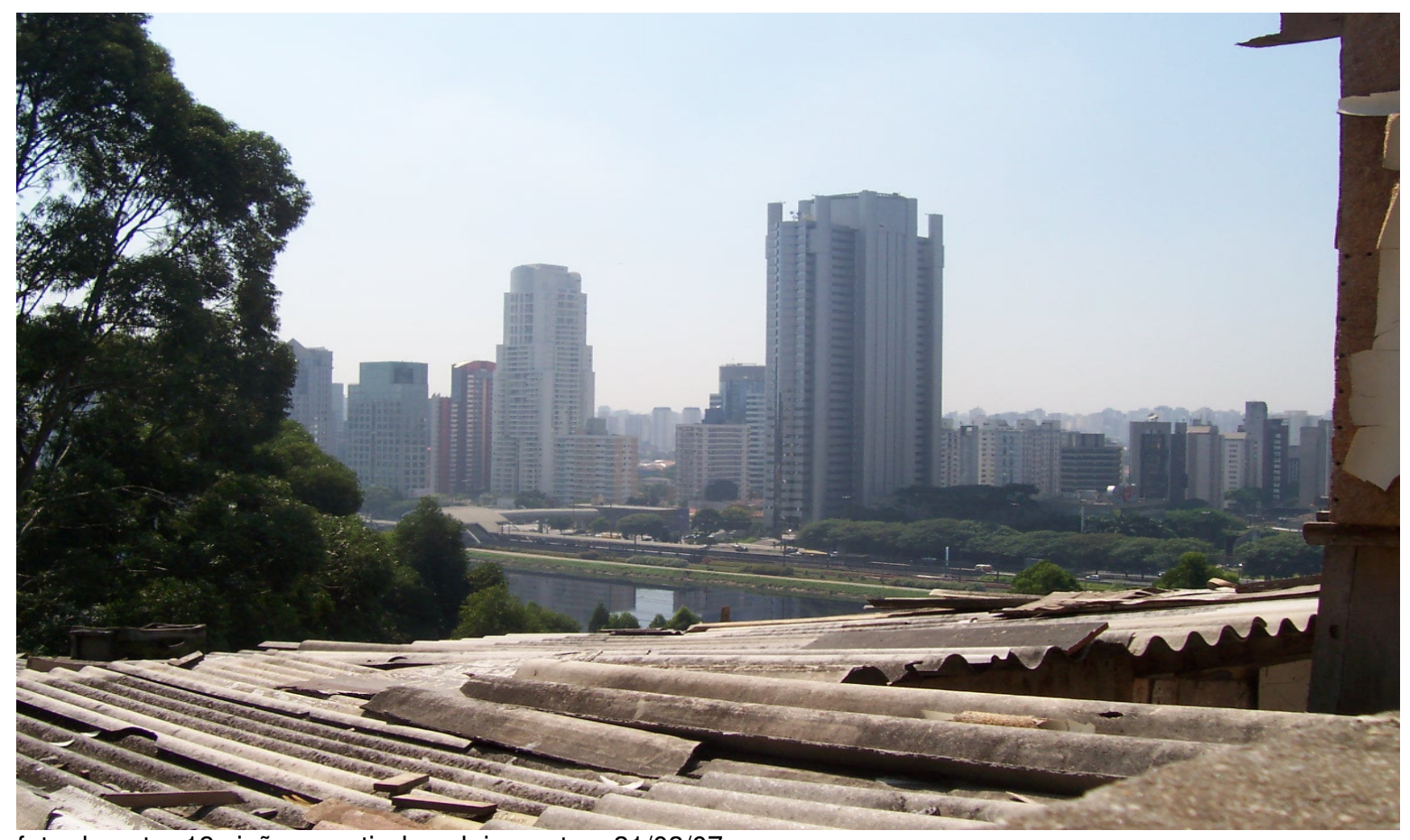

foto do autor 18 visão a partir dos alojamentos. 31/03/07.

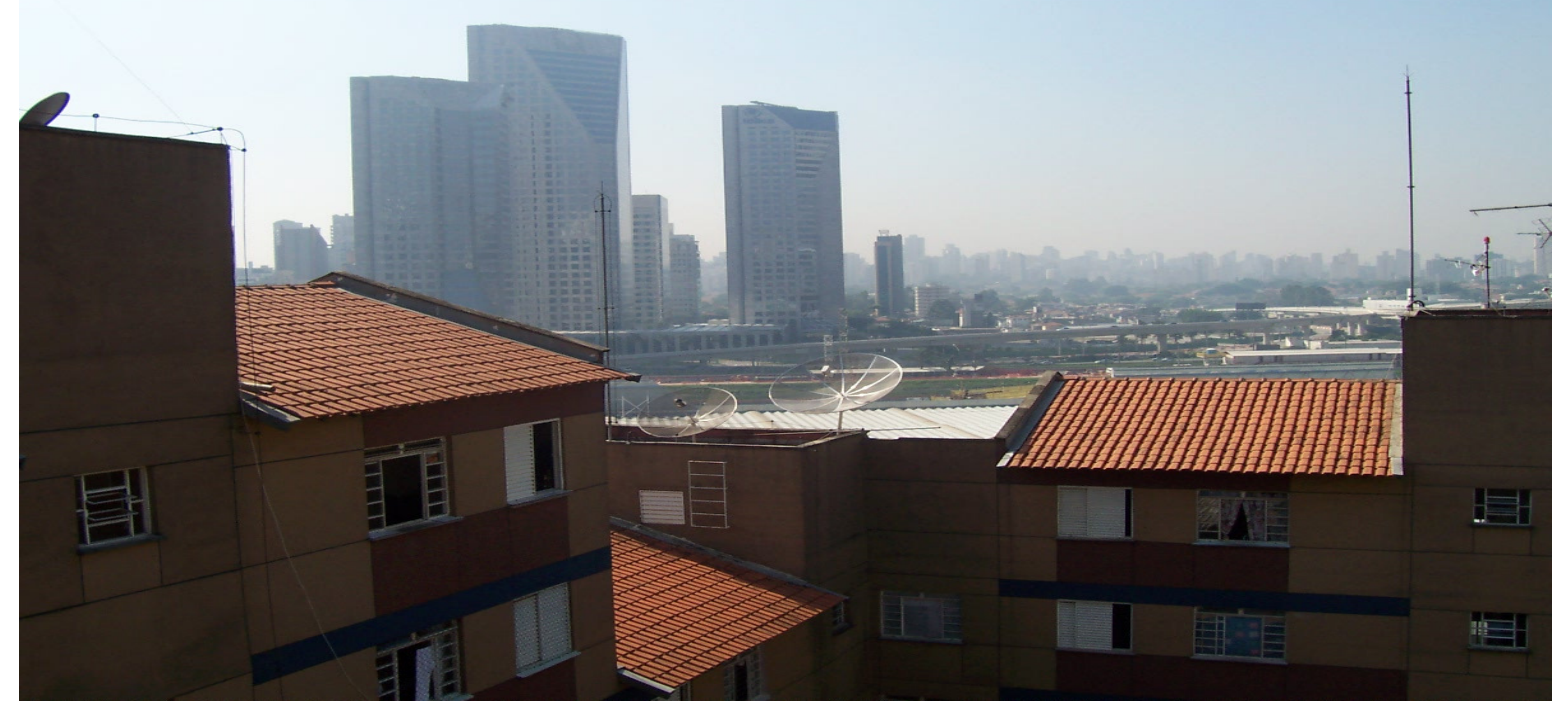

foto do autor 19 visão a partir do Cingapura. 31/03/07.

Mas de acordo com Milton Santos (1998:31) "o que existe são temporalidades hegemônicas e temporalidades não hegemônicas ou hegemonizadas". E, assim, o fato de ter acesso a computadores e cursos de informática não é suficiente para que as pessoas moradoras da favela da Mandioca se globalizem, no entanto não deixam de estar sendo globalizadas, bem como o espaço que ocupam, que passa a dispor de símbolos "globais" 
(antenas parabólicas e lan house), mas não é e não chega a ser, um lugar global que venha a participar exercendo funções de coordenação e operação (emissão e recepção) de sistemas econômicos globais.

Por outro lado, com relação à ação do Poder Público para com a melhoria das condições de vida das pessoas em situação precária e de risco, vamos notar que aparecem nos documentos oficiais - Planos Regionais Estratégicos das Subprefeituras ${ }^{24}$-, quadros № 04B do Livro X, anexos à Lei oㅡ 13.885, de 25 de agosto de 2004 - a favela da Mandioca classificada como Zona Especial de Interesse Social - ZEIS, conforme segue:

.ZEIS 1 - W044 (BT)

Inicia-se na confluência da Rua Conde de Itaguai com a Rua Cesar Vallejo, Rua Cesar Vallejo, segmentos 1-2-3 (divisa dos lotes 5,11 e 12 com os lotes 37 a 24, 41, 40, 21 a 13 e 4 da quadra 52 do setor 300 da Planta Genérica de Valores), Av. Duquesa de Goiás, Rua Paulo Bourroul, segmento 4-5 (divisa dos lotes 56 e 4 com os lotes 57 e 5 da quadra 49 do setor 300 da Planta Genérica de Valores), Rua Conde de Itaguai, Rua Barão de Castro Lima, segmento 6-7 (divisa dos lotes 31 e 20 com os lotes 30 e 19 da quadra 48 e, em seguida, divisa dos lotes $23,2,3,4,5,6,24,25,8,9$ e 10 com os lotes 22 e 28 da quadra 47 do setor 300 da Planta Genérica de Valores), Rua César Vallejo até o ponto inicial. (Plano Regional Estratégico da Subprefeitura do Butantã PRE-BT).

Apesar do reconhecimento como área de risco e de interesse social, localizada e reconhecida em documento oficial, a única ação concreta do Poder Público em relação à população em área de risco neste lugar parece ter sido a construção dos Conjuntos Habitacionais Cingapura que aconteceu anteriormente à Lei $\mathrm{n}^{\circ} \mathbf{1 3 . 8 8 5 .}$

Assim como acontece com parte residual da favela do Jardim Edith junto a Berrini, na favela da Mandioca existe a intenção oficializada em documentos, mas não há, por enquanto, ação concreta do poder público em realizar o interesse social, no caso a construção de moradias populares e a urbanização da favela.

\footnotetext{
${ }^{24}$ http://sempla.prefeitura.sp.gov.br/urb_zon.php
} 
$\mathrm{Na}$ ausência de uma política efetiva de urbanização, vamos observar nas fotos 20 e 21 que o sistema de autoconstrução é o que está sendo realizado pela população local. Mas o que "animou" ou está estimulando estas ações pontuais?

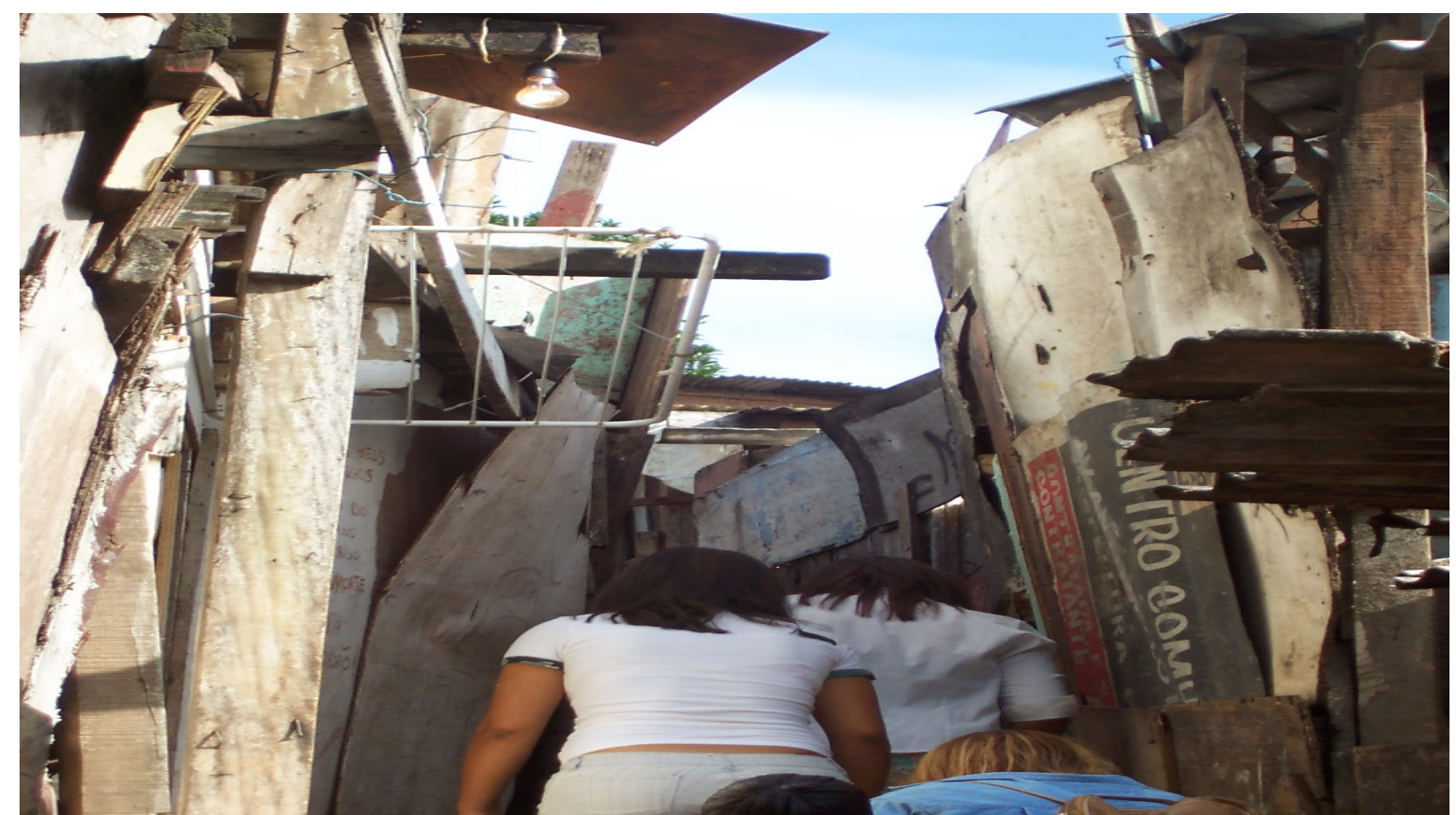

Foto 20 do autor fevereiro de 2006 - interior da favela da Mandioca, predominância de barracos.

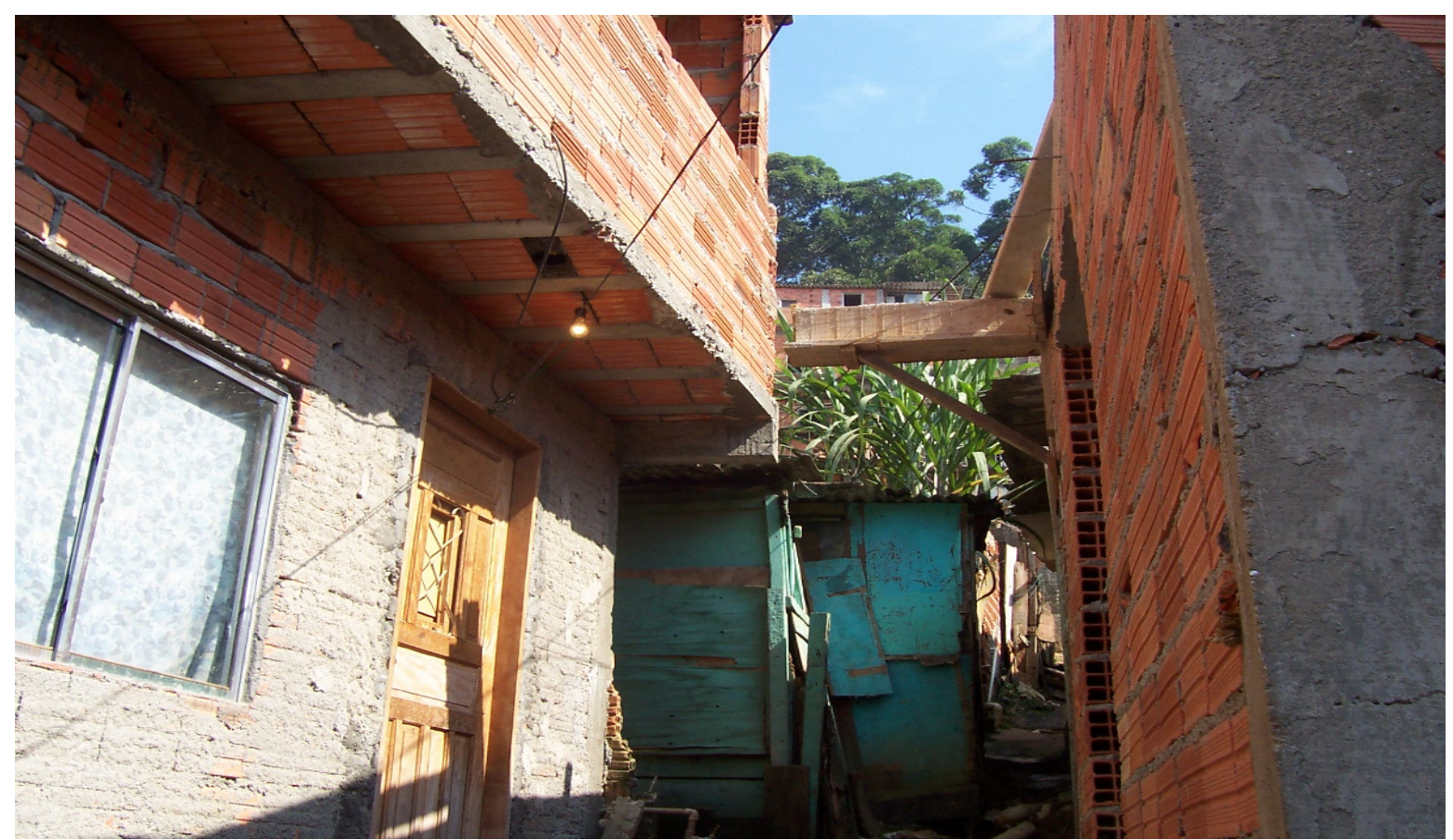

Foto 21 do autor março de 2007 - interior da favela da Mandioca, substituição dos barracos por casas de alvenaria. 
No Plano Diretor Estratégico parte II que dispõe sobre as Áreas de Intervenção Urbanas, a prioridade para a Subprefeitura do Butantã foi a AlU de Vila Andrade/Paraisópolis, que de fato está sendo reurbanizada com a publicação dos decretos que permitem a doação de imóveis em troca do perdão de dívidas e, doação em troca da certidão de potencial construtivo transferível.

\section{Decretos regulamentam a doação de imóveis em Paraisópolis}

Texto: Graco Braz Peixoto

D ois decretos publicados hoje facilitam a regularização de imóveis no Complexo Paraisópolis, a segunda maior favela de São Paulo. 0 primeiro permite que donos de imóveis do loteamento original de Paraisópolis que tenham acumulado dividas de IPTU com a Prefeitura ou outras multas de edificaçōes poderão doá-los à Municipalidade em troca do perdáo das dividas.

Outro decreto regulamenta a doaçào de terrenos sem dividas à Prefeitura em troca da certidáo de potencial construtivo transferivel, a ser utilizada de acordo com o Plano Diretor Estratégico e os Planos Regionais Estratégicos. 0 proprietánio poderá negociar esse titulo com terceiros. Assim caso não lhe interesse o potencial construtivo, ele poderá vendê-lo a uma construtora, por exemplo. A Secretaria Municipal de Planejamento fará o controle da transferência do potencial construtivo.

Os imóveis destinados ao Programa de Regularizaçâo e Uribanizaçáo do Complexo Paraisópolis sáo aqueles situados dentro dos perimetros correspondentes às Zonas Especiais de Interesse Social ZEIS, criadas por lei em 2004, de acordo

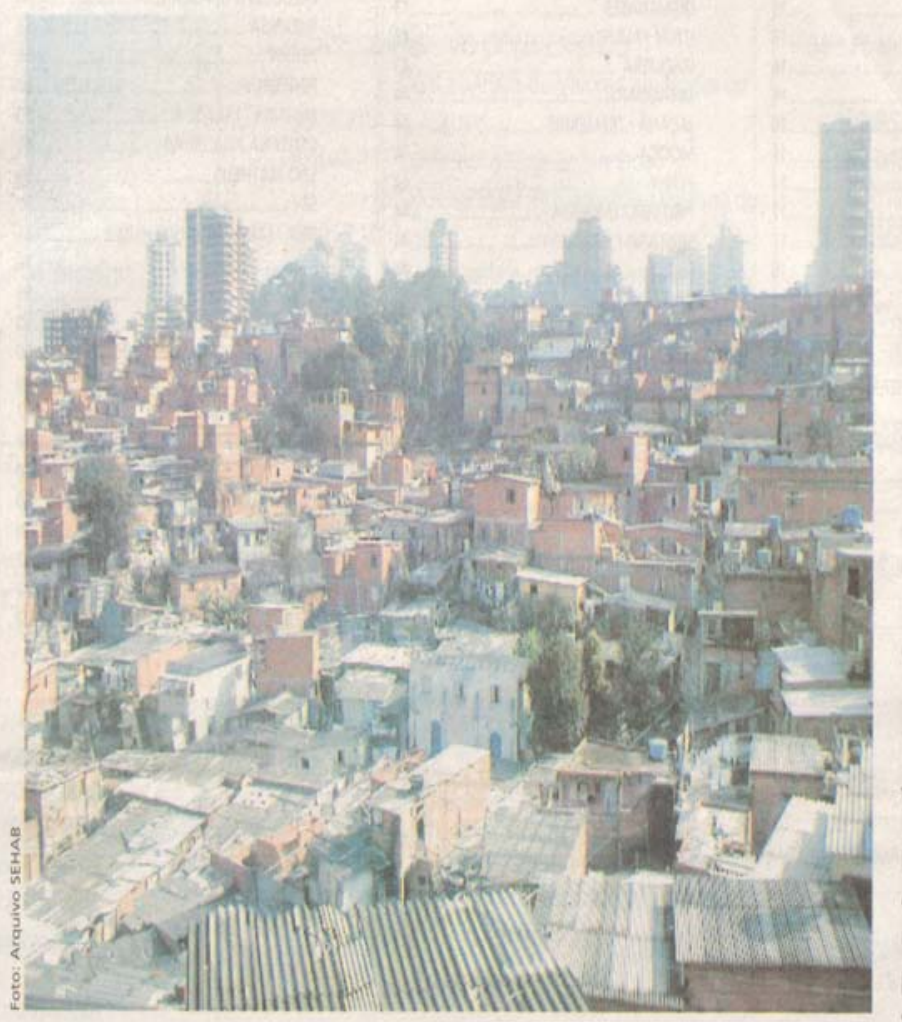

prietários desses imóveis, por publicaçáo no Diário Oficial da Cidade e no site da Prefeitura, junto aos Conselhos Gestores e à comunidade local, além de outros meios de comunicação, para manifesta. rem interesse na doaçáo.

0 instrumento da transferência do direito de construir ainda nảo havia sido regulamentado no Municipio de São Paulo. Até o momento ele é previsto apenas para as ZEIS do Programa Paraisópolis, cujo ob. jetivo é integrar o chamado Complexo Paraisópolis à cidade formal através da regularização urbanistica e fundiária, promovendo a inclusảo social pelo acesso danhia de Desenvolvimento Habitacional no prazo de 60 dias, contados da publi- quela comunidade à infra-estrutura e Urbano (CDHU). caçáo dos decretos, promoverá a divul- urbana, com boas condiçōes ambiengaçáo e chamamento público dos pro- tais, de saúde e moradia.

Fonte: Diário Oficial da Cidade de São Paulo - 30/03/2006.

Apesar de não aparecer como prioridade nos documentos oficiais, a população da favela da Mandioca, em contato com a população da favela Paraisópolis, acredita que o mesmo deverá acontecer no Real Parque, à medida que se comparam da seguinte forma com os remanescentes do Jardim Edith: 
Então a oportunidade para eles desapropriarem lá é agora com a ampliação da Avenida da Água Espraiada ali que é Roberto Marinho agora, com a ampliação o que eles fizeram, eles tiraram só a parte que eles ia alargar a rua que foi o que eles fizeram alargaram a Avenida Roberto Marinho e deixaram o pessoal lá, fizeram um muro de proteção ali protegendo a Avenida e o pessoal continua lá (Wanderley 14/03/07)

Ali o pessoal se amontoa porque tem gente que faz barraco em cima de barraco (Maria Aparecida14/03/07)

$\mathrm{E}$ ali é bem menor que Real Parque ali deve morar o quê umas mil pessoas ali pela quantidade de barracos, aqui nos temos uma comunidade de quase 5 mil pessoas que moram aqui (Wanderley 14/03/07)

Aquela favela ali dava três dessa daqui, dava três, eu andava ali (Maria Aparecida 14/03/07).

Você viu como ficou aquilo ali? Ficou tão pequeno.(Wanderley 14/03/07)

Os moradores entendem que seja "até normal" a retirada dos que permanecem no Jardim Edith uma vez que já era para ter sido desapropriado com a ampliação da Avenida Água Espraiada, possuir gente que constrói barraco em cima de barraco, aumentando o risco, além de uma população bem menor que a do Real Parque, cerca de cinco vezes maior. Dessa forma acreditam que as condições na favela da Mandioca são melhores do que a da favela Jardim Edith e por isso ser mais difícil de sofrerem uma desapropriação.

Contudo o processo de ampliação da Água Espraiada e a retirada da favela do Jardim Edith aconteceu de forma surpreendente para muita gente e não apenas para a população favelada que morava nessa região, como podemos entender no relato de Alberto Botti, apud FIX (2003:179)

... O projeto da Águas Espraiadas tinha uma proposta muito inteligente - criar, ao longo da avenida habitações populares. Diga-se de passagem que as favelas que 0 Maluf removeu, voltaram para lá. Havia um projeto de reserva de área na região para abrigar aquelas famílias. E por que na região? Porque quando se mexe com uma favela, não adianta remover a comunidade para uma área distante, pois a vida daquelas pessoas vincula-se ao local de origem. Tínhamos uma proposta que envolvia 0 remanejamento daquela área na ordem correta, ou seja, 
primeiro faríamos os abrigos, para depois levar os favelados.(18/08/2003)

Os moradores da favela da Mandioca parecem não levar em conta que os interesses de classe, defendido por alguns, acabam produzindo posições e posturas que são surpreendentes até mesmo para aqueles que pensam e planejam a cidade. Alberto Botti denuncia, na entrevista acima, que havia um projeto de habitações populares e uma proposta de remanejamento da população que não se realizou. Mariana Fix (2001) acompanhou e registrou todo o processo em que boa parte da população da favela do Jardim Edith foi "expulsa" para as áreas de mananciais, agravando a situação das pessoas e daquela região.

Assim mesmo e sabendo que o local onde moram pode sofrer uma ação semelhante à do Jardim Edith assim como já serviu e continua a servir como possibilidade de uso político econômico, os moradores da favela da Mandioca esperam permanecer e conseguir melhores condições de vida onde estão e explicam como, na visão deles, as favelas não acabam:

existe ainda muita favela e o interesse político é muito grande em torno disso aí, pelo fato de gerar recursos para eles, entende? A favela é um grande, tipo é um grande comércio porque, se acabar as favelas, eles não vão ter aonde alegar que tá investindo dinheiro, investindo e, também ta desviando pra eles né, tá gerando recursos pra eles, superfaturando essas obras aí, acho que é por isso, o grande desinteresse deles em acabar com as favelas, porque sempre ele vai ali, tem uma favela vem um governador, um prefeito, vai lá tira um pedacinho dela só, urbaniza aquilo ali e faz o marketing dele em cima daquilo e, acaba ficando ainda a favela e continuam os problemas (Wanderley 14/03/2007)

Que nem esse conjunto aí na frente foi só para esconder a favela (Maria Aparecida 14/03/2007)

É, foi só para esconder, o que o Maluf fez aí. (Wanderley 14/03/2007).

Os relatos do Sr. Wanderlei e Dona Maria Aparecida deixam evidente que as pessoas não são ingênuas e não se deixam enganar facilmente, mesmo as que formam o grupo dos agentes não hegemônicos, que foram de "certa forma emparedadas" na administração do Prefeito Paulo Maluf (1993-1996), quando da 
construção de alguns edifícios Cingapura em frente à favela da Mandioca, escondendo o restante da favela que também deveria ter sido reurbanizada e não foi. Permaneceu "escondida" atrás dos edifícios (foto 22), que acabaram funcionando como tapumes, em uma tentativa de não deixar transparecer a permanência da precariedade social naquela região, já que os recursos não foram aplicados devidamente.

A favela não só continuou a existir como passou a abrigar também um alojamento precário de madeira, construído pela prefeitura, que deveria ser provisório, para alojar os moradores das áreas de risco até a construção dos novos Cingapuras. No entanto permanece como marca do descaso do poder público na Gestão Maluf, que utilizou recursos públicos indevidamente com o superfaturamento de obras, enquanto a população da favela da Mandioca permaneceu sobrevivendo precariamente.

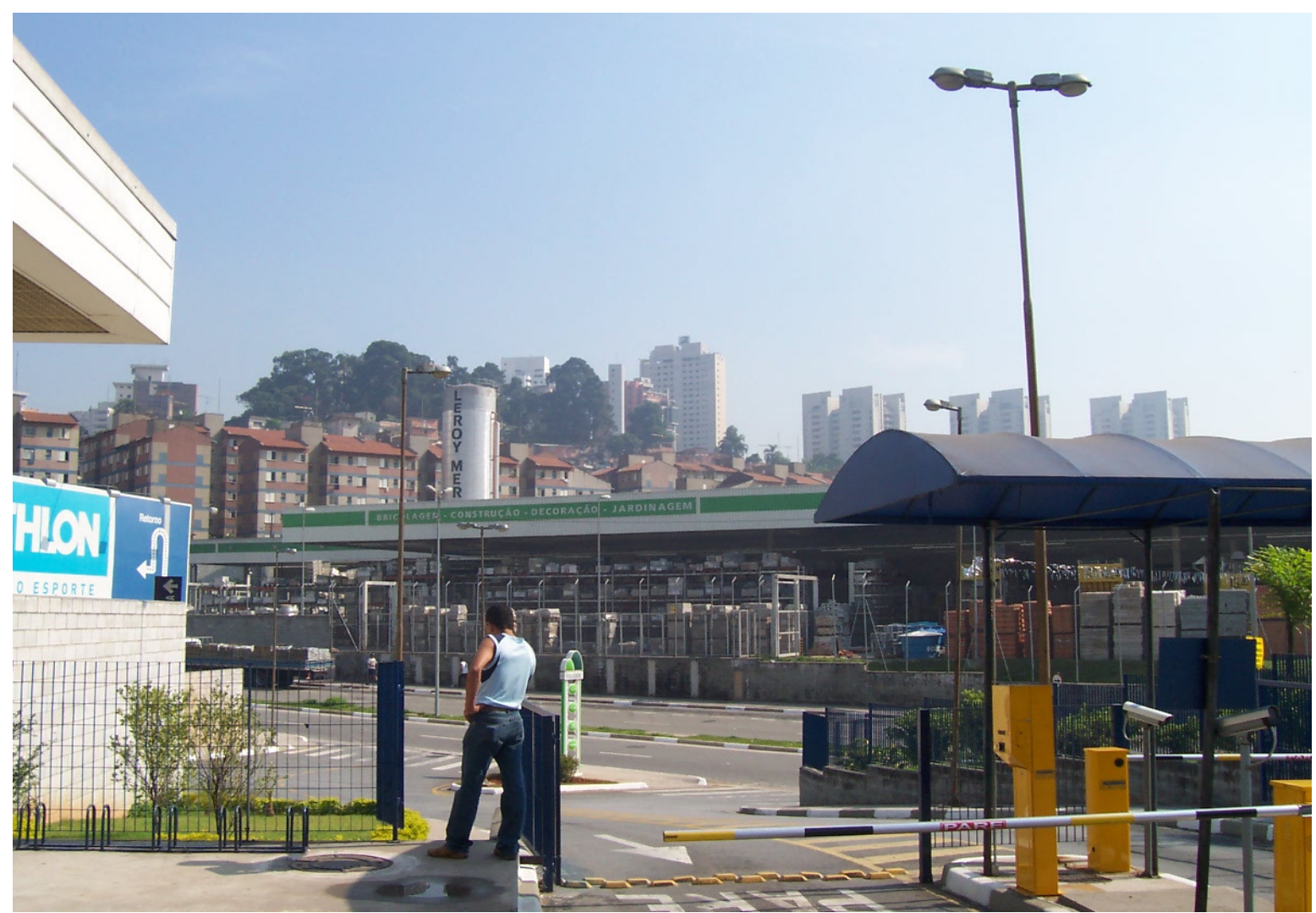

foto 22 do autor março/07- visão do Pão de Açúcar Marginal Pinheiros para a favela da Mandioca, o Conjunto Cingapura encobre a favela que existe atrás. 
Apesar das inúmeras dificuldades, os moradores da favela, do alojamento e do conjunto Cingapura possuem capacidade para entender quando estão sendo usados. Nas falas dos entrevistados se reconhece que a favela é "um grande comércio" e que é utilizada por "alguns dirigentes políticos" como justificativa para investimentos que, na realidade, não acontecem e servem para a promoção pessoal, na criação de uma imagem de "líder que defende os menos favorecidos", mas de acordo com os entrevistados, isso acontece porque esse dirigente político "faz o marketing dele em cima daquilo", conseguindo enganar muitas pessoas.

A colocação desses moradores demonstra que existe, na posição deles, um esforço em saber como funcionam as relações políticas para defenderem seus direitos de permanência no local de moradia.

Esta preocupação fica mais evidente quando estabelece relações com as demais áreas precárias do entorno. Ao serem questionados em relação ao projeto que havia da construção de um conjunto habitacional junto a Berrini, que fez parte do Projeto proposto durante a administração da Prefeita Marta Suplicy (PT de 2001 a 2005), como constatamos em um projeto junto ao Complexo Viário Real Parque e que até o momento não está sendo realizado, entendem que isso ocorre:

\begin{abstract}
Porque essa nova gestão aí o interesse deles é o interesse comercial se eles desapropriar ali por isso que eles jogaram, engavetaram esses projetos porque é muito mais lucro para eles desapropriar e pegar um investimento dos empresários do que eles criar um conjunto popular habitacional. Eles acha que são contra o projeto da Marta por isso que eles não deram continuidade, porque se não pelo tempo que eles estão já era para ter feito ou pelo menos ter iniciado e como eles engavetaram isso aí é esquecido. (Wanderley14/03/07).
\end{abstract}

Para alguns moradores, como o Sr. Wanderley, existe uma estratégia entre poder público e privado para utilizar o espaço como possibilidade de reprodução do capital e, desse modo, o interesse social sempre fica "engavetado" e cai no esquecimento. 
Já em relação ao processo de desapropriação que podem sofrer e em comparação ao processo pelo qual passa a favela vizinha, do Jardim Panorama, cercada por condomínios luxuosos e agora também pelo Shopping Center "Cidade Jardim", que deverá atender a um "público de um poder econômico muito alto", afirmam:

É faz muitos anos que tá essa briga para tirar o Panorama, mas eu acho que aqui é bem difícil de sair por causa do Cingapura né. Agora o Cingapura a partir de maio todo mundo recebeu as cartas, agora todo Cingapura é da Caixa Econômica Federal é subsidiado pelas obras da CDHU, então acho que é por isso que sair daqui é difícil porque a partir de maio todo mundo vai pagar a documentação como CDHU (José Roberto 14/03/07).

Diante da perspectiva de não serem desapropriados, já que os conjuntos de apartamentos do Cingapura serão transferidos para a Caixa Econômica e os moradores se tornarão proprietários e de que, assim como aconteceu em Paraisópolis, a favela da Mandioca deverá ser reurbanizada, muitos moradores se animaram e começaram a refazer suas casas, substituindo os barracos de madeira por alvenaria, em regime de autoconstrução, conforme foto 23 , onde podemos visualizar boa parte da favela. 


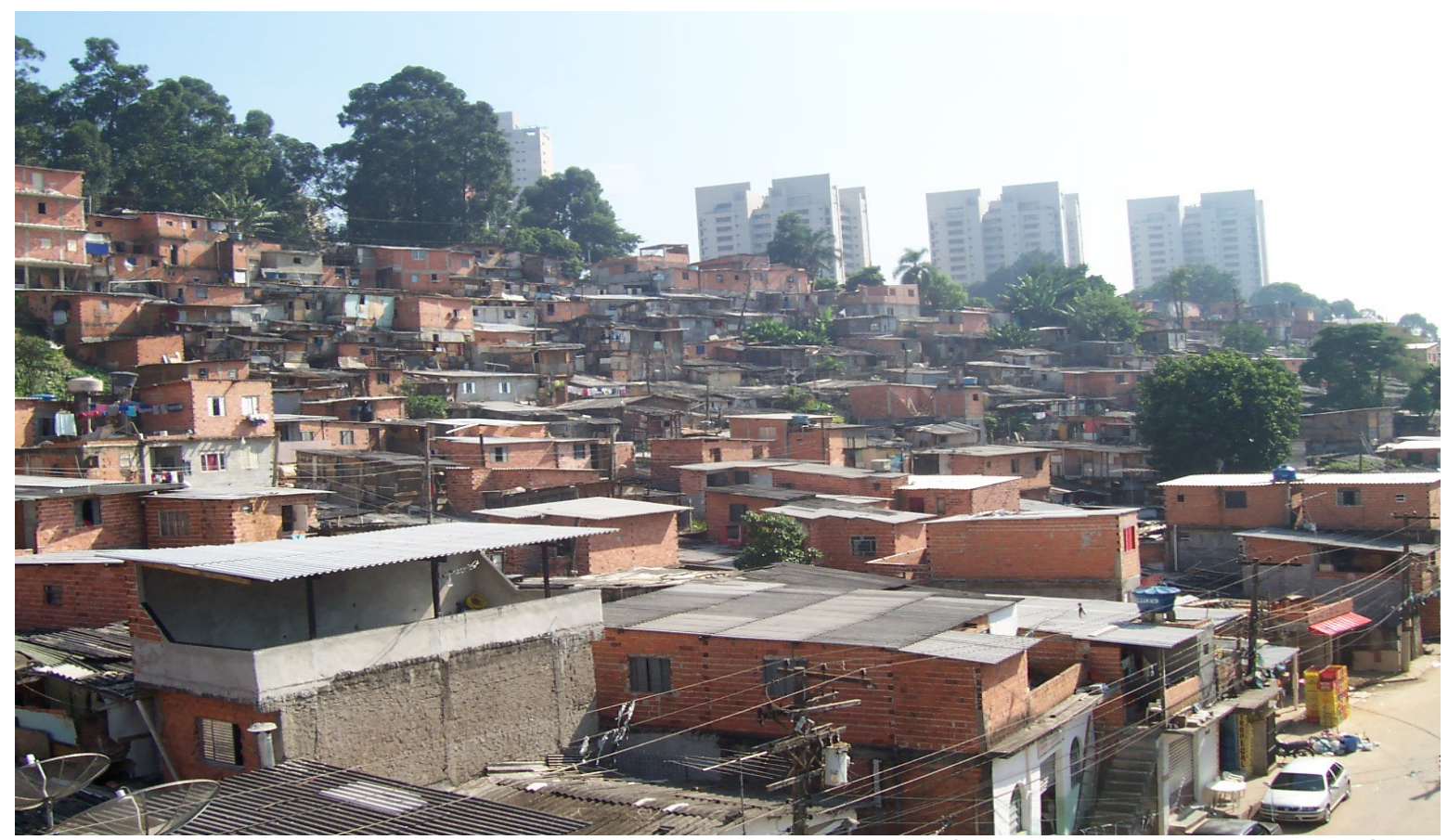

foto 23 do autor abril 2007 visão da favela da Mandioca a partir do Cingapura, percebemos que há um predomínio de casas de alvenaria.

Nesta visão de conjunto, podemos perceber que a maioria dos barracos foi substituída por casas de alvenaria, indicando uma forte posição da população em permanecer e valorizar seu local de moradia.

Porém a construção de casas de alvenaria contribuiu para um maior adensamento das "propriedades", ainda que precárias, já que não existe uma escritura de posse oficial no interior da favela. Com isso, o espaço se tornou mais ocupado e, simultaneamente, mais caro.

Esta condição de ocupação dinâmica do espaço nessa localidade, abre a possibilidade para a especulação, por parte de alguns, com o desejo de "levar vantagem", conseguindo um ganho a mais explorando outros, utilizando para isso o uso do solo no interior da favela; o que acaba por reproduzir ou se assemelhar a algumas práticas de reprodução capitalista do solo urbano, onde a especulação tem sido uma das práticas para se conseguir maiores ganhos. De acordo com o Sr. Wanderley (14/03/2007):

Lá é um mato, é um mato, é umas chácaras, inclusive aquele terreno, uma parte, é do padre que pertence a lgreja Católica, só que o pessoal vai invadindo ali, eles sabe que já foi desapropriado, inclusive policia entrou lá 
desapropriaram um tempo atrás aí desapropriaram, só que o pessoal volta a ocupar ali por gerar recursos entendeu? Eles vão ali não mais por parte de morar, eles vão ali constrói um barraco e começa ocupar por uns dias depois vende para outro e vai gerando (...) especulação.

A prática da ocupação ilegal de terrenos, "o pessoal volta a ocupar ali por gerar recursos", junto à favela e a venda para outras pessoas com maiores necessidades, se assemelha ao que alguns especuladores fazem ao lotear áreas que não podem ser ocupadas por residências junto às represas; portanto, área de proteção aos mananciais, que os especuladores têm todo o conhecimento da ilegalidade, mas exploram. Os menos favorecidos, por não terem alternativa e por desconhecimento, compram os lotes em áreas que não podem ser ocupadas.

$O$ adensamento na ocupação do espaço que explica, pelo menos em parte, a relação centro-periferia na produção da cidade, em que a explosãoimplosão do Centro estruturou as periferias e agora, como vimos, o desdobramento de sua centralidade alcançou e começa a englobar a periferia, ajuda a entender as relações que se estabelecem no interior da favela em relação ao uso do solo:

Lá a área é ruim, eles fazem o barraco, a área é ruim, faz o barraco, vem outra pessoa, o barraco é barato lá, prá cá é caro, prá cá é caro, aí vende, sem tem uma reserva, tem uma economia, tem gente que faz dois, três barracos, vende tudo aqueles barracos (...) lá na encosta, aí desce compra melhor cá pra baixo, compra coisa melhor cá pra baixo.(Maria Aparecida 14/03/2007).

A prática relatada por Dona Maria Aparecida de que "tem gente que faz dois três barracos, vende tudo aqueles barracos", demonstra que o processo de reprodução do espaço urbano que cria uma hierarquia espacial, abre a possibilidade da reprodução das relações capitalistas de exploração, onde os menos favorecidos serão explorados por alguns que especulam o espaço, enquanto mercadoria reprodutível, ampliando a desigualdade social. 
O que está sendo relatado acima pode ser comprovado na foto 24 abaixo, o barraco "novo" está na encosta, acima próximo aos alojamentos, existem muitos em condições piores.

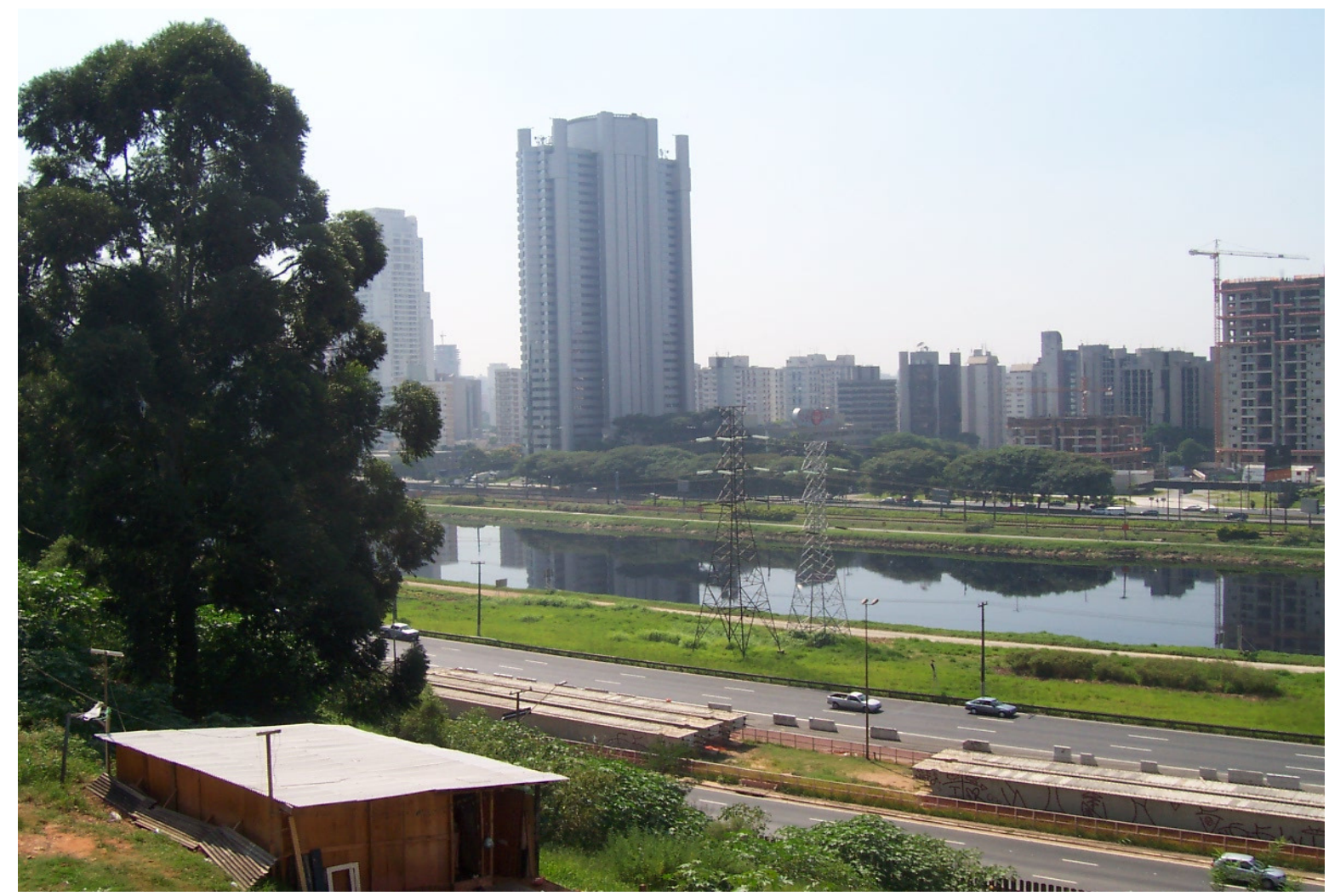

Foto 24 do autor abril 2007 - encosta favela da Mandioca - face para Marginal do Rio Pinheiros.

A precariedade dos barracos que ficam atrás dos alojamentos e a exploração das pessoas em condições mais penosas, de extrema pobreza, foto $\mathrm{n}^{\circ}$ 25 , demonstram que as relações de especulação imobiliária que ocorrem por toda a cidade, dentro da mesma lógica de produção, foram apreendidas e estão sendo reproduzidas neste local. 


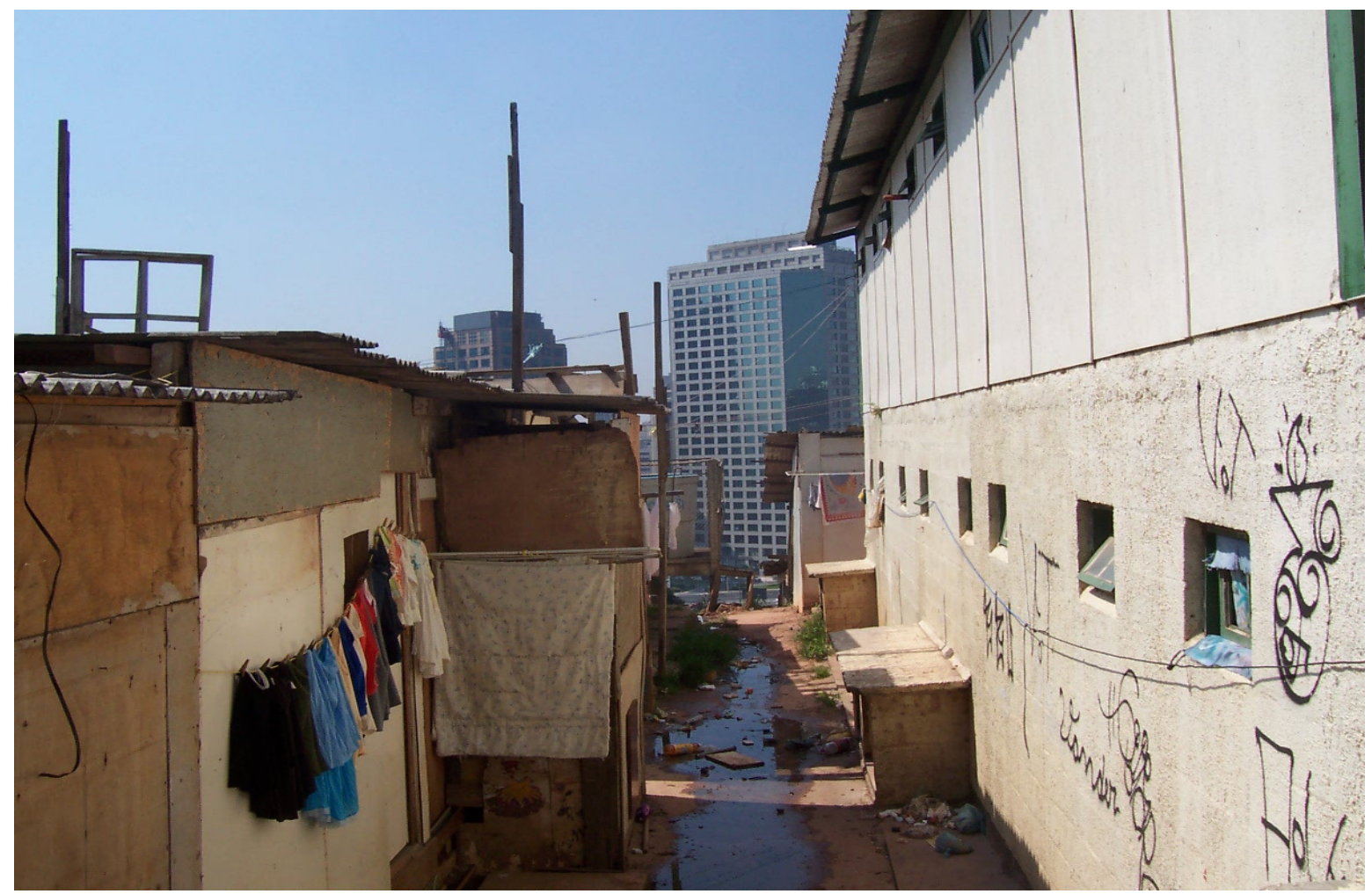

foto 25 do autor abril de 2007 - início dos barracos construídos atrás dos alojamentos, na encosta com face para a Marginal do Rio Pinheiros

Quanto ao uso do espaço, vamos notar que também reproduz a mesma lógica do Centro e da expansão da cidade: "Lá a área é ruim, eles fazem o barraco, a área é ruim, faz o barraco, vem outra pessoa, o barraco é barato lá, prá cá é caro, prá cá é caro" (Maria Aparecida). Assim como as classes menos favorecidas foram sendo empurradas para as áreas com pouca ou nenhuma infraestrutura, nas bordas da cidade, entre o urbano e o suburbano, onde acabavam e continuam a ser alvo dos especuladores imobiliários, é o caso das áreas de proteção de manancial junto às represas Billings e Guarapiranga, onde a população de baixa renda é explorada com loteamentos clandestinos realizados por pessoas inescrupulosas, que sabem da ilegalidade em áreas que não poderiam ser ocupadas para fins residenciais.

Em relação aos acordos políticos que permitem a reordenação do solo urbano, como mudança de zoneamento em algumas áreas, permissão do aumento do índice de construção em outras, desapropriações e licitações duvidosas com empreiteiras e construtoras, sendo que muitas vezes esses acordos são inexplicáveis - caso da Operação Urbana Água Espraiada, nas 
gestões de Prefeito Paulo Maluf e Celso Pitta - conforme noticiou a folha de São Paulo em 18/02/2005:

Os promotores Silvio Marques e Sérgio Turra sustentam que Maluf teria desviado recursos da construção da avenida Agua Espraiada --atual jornalista Roberto Marinho-- e do túnel Ayrton Senna, durante sua gestão na Prefeitura de SP (1993-1996). O esquema teria continuado na gestão Celso Pitta (1997-2000).(Folha on line).

Mesmo com a sustentação dos promotores, não houve conclusão do processo, tanto Paulo Maluf quanto Celso Pitta ficaram impunes da acusação. $O$ que expõe a maneira como o espaço da cidade vem sendo produzido, em determinados momentos, ou seja, o poder público é utilizado em benefício particular, por meio da reorganização espacial que deveria servir a um conjunto de benefícios sociais como moradias, transporte, lazer, etc.

$\mathrm{Na}$ favela da Mandioca e, na ausência do poder público, quem organiza e reorganiza o espaço reproduz uma relação semelhante às de Paulo Maluf e Celso Pitta, em relação ao uso do solo, porque:

para ter um barraco ali tem que ganhar o chão de alguém, alguém tem que dar o chão. Eles tem que pedir aquele chão para alguém , também não é chegar assim e pegar o chão,o chão é ganhado de alguém, alguém tem que dar o chão. $O$ dono é o padre, a prefeitura. (Maria Aparecida)

Da mesma forma que o Poder Público dispõe com o amparo da legislação sobre o solo urbano para realizar o bem público e é necessária uma autorização para se fazer o uso particular, na favela tem que "pedir o chão para alguém", independente se este solo pertence ao padre ou a prefeitura. Questionada sobre quem autoriza a construção, Dona Maria Aparecida responde:

Ah! Os meninos dão o chão. Os que controlam a favela dá o chão. Chega ali invade como se fosse deles entendeu? Só quem tem poder de mexer mesmo é só a Prefeitura, aí se vai indenizar ou não quando eles vierem a pessoa fala, eu não tenho para onde ir, e não tem mesmo, não tem condições. (Maria Aparecida 14/03/07). 
O espaço da favela, seu uso, serve como mercadoria para os que controlam suas relações; "os meninos dão o chão", permitem ou não a ocupação e o uso, geralmente em troca de alguma coisa. De certa forma, legislam sobre o espaço e, novamente, o que deveria ser de benefício social coletivo, acaba servindo a interesses muito particulares de alguns.

Nesta relação há o uso indevido do espaço por meio do Poder Público ou de outro "Poder" que organiza e reorganiza o espaço, concedendo "favores", quer dizer, o uso ilegal de um recurso público para conseguir benefícios pessoais, como os "recursos da construção da Avenida Água Espraiada", caso do Prefeito Maluf , conforme afirma Dona Maria Aparecida (14/03/07): "o que os meninos ganham? Só ganha o silêncio, haja o que houver, só tem que tá de bico fechado é aquela lei: não sei, não vi”.

Existe uma reprodução das relações de "favores" que acaba gerando uma vantagem comparativa para poucas pessoas, que privilegiadas com 0 acesso a determinadas áreas e informações de como será, ou não, as reorganizações de determinado espaço, tiram proveito pessoal, realizando o processo de especulação imobiliária, conseguindo ainda, em alguns casos, propinas ou favores, como acontece na favela da Mandioca com a política do "não sei, não vi ou sou cego, surdo e mudo". Os envolvidos nesse processo entendem que é assim mesmo, porque até mesmo na administração do dinheiro público municipal, que deveria ser utilizado para a resolução dos problemas sociais, o procedimento acaba sendo mais de "favores" e de desvios:

pelo que eu já ouvi comentários cada barraco desse aí custa para a Prefeitura em torno de 20 mil reais, só que no morador mesmo, que mora que ocupa aquele barraco, recebe 5, 6 mil reais ou de 3 a 6 mil reais por aquele barraco dependendo de tamanho e a família dele, e esses outros 14 mil vai pro bolso de quem? Eu não sei, entendeu? Só dos intermediários e de quem fez o movimento para tirar aquelas pessoas, aí eles chega para o morador, o morador assina um papel, tipo como se fosse em branco, dali eles faz um recibo, só que por trás daquilo ali, tem um outro valor que é deve ser correspondente mais ou menos em torno de 20 mil e o morador acaba ficando com de 3 a 6 mil reais e 0 restante ninguém sabe para onde vai (Wanderley 14/03/07) 
A favela da Mandioca reproduz em um nível local as relações que muitas vezes ocorrem em um nível Municipal, utilizando procedimentos exemplares de "muitos políticos", ou seja, alguns tiram proveito pessoal da situação dos demais usando o recurso público indevidamente (dinheiro e solo urbano) e, da mesma forma que desejam fazer parte da sociedade de consumo, também tentam reproduzir a mesma lógica de produção do capital que produziu a periferia onde moram. $\mathrm{Na}$ foto 26 vemos construções de garagens junto ao conjunto Cingapura, a ocupação do espaço que deveria ser pública, utilizada de forma privada, servindo, muitas vezes, como fonte de renda ao serem alugadas.

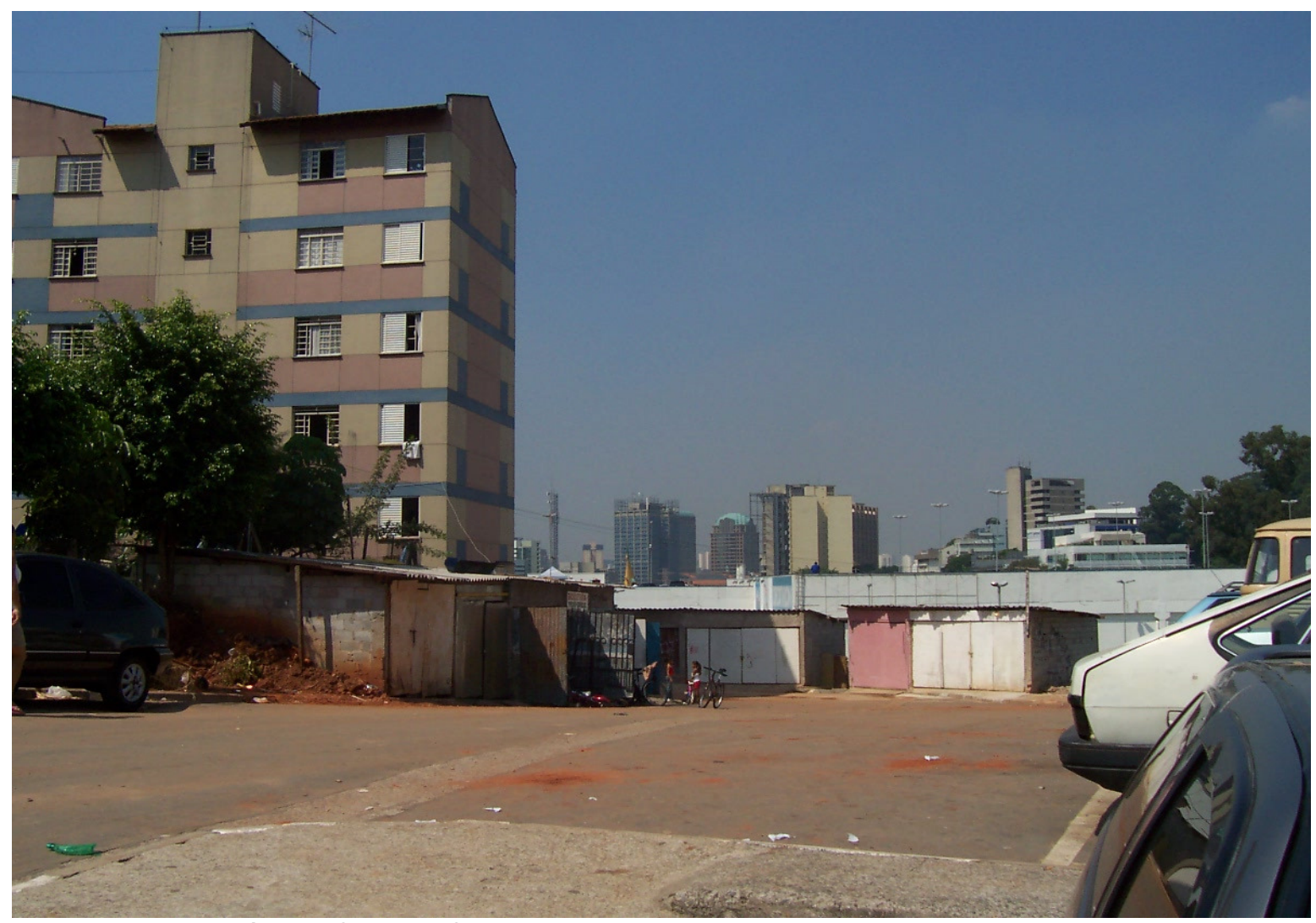

foto do autor 26 - início do Conjunto Cingapura na Rua Paulo Bourroul, garagens.

Embora a população resista com relação a permanecer na região, não resistem ao modelo de produção que gerou a periferia e a favela e que tem, muitas vezes, ocasionado a "expulsão" da população não hegemônica para áreas cada vez mais distantes e precárias. Demonstram o desejo de se sentirem parte, da estarem incluídos, ainda que entendam que o sistema produtivo vigente seja perverso. 
Lembra o romance "A especulação imobiliária", de Ítalo Calvino, em que um de seus personagens, de nome Quinto, um intelectual, não resiste aos encantos do capital, acreditando que se salvará economicamente sendo um especulador imobiliário:

"A minha superioridade em relação a eles", pensava Quinto,
"é que eu ainda possuo o instinto burguês, que eles
perderam no desgaste das dinastias intelectuais. Me
agarrarei a isso e me salvarei, enquanto eles se esfacelarão.
Tenho que ter uma atividade econômica, não basta que eu
venda o terreno a Caisotti, eu também devo construir, farei
uma casa perto da que fará Caisotti com o dinheiro que me
pagará..." Concentrou o pensamento na possibilidade
imobiliária que o terreno ainda oferecia, nas possíveis
negociações... (1986:51)

$\mathrm{Na}$ favela da Mandioca, os instintos burgueses ou capitalistas de lucrar por meio do uso do solo na construção ilegal de garagens ou de barracos, nas encostas, para serem vendidos, reproduz a especulação imobiliária. Até mesmo aquelas pessoas que estão em situação precária, devido à própria especulação, acabam se tornando especuladoras e se agarram nas possibilidades de conseguir uma renda maior, a qualquer custo, mesmo sabendo que o "negócio" que estão realizando é ilegal.

Por outro lado, este tipo de ação estimula o individualismo enfraquecendo a força da comunidade, o que esclarece, um pouco, a fala de Dona Maria Aparecida :

o povo dessa favela são muito sossegado, porque aqui não tem um presidente fixo nessa favela, porque quando entra um, é época de política, sempre vai até um presidente, sempre vai até alguém da comunidade. Aí é só uma política porque eles se beneficiam né. Aí acabou a política, acabou o cargo (14/03/07).

Não existe uma organização permanente da comunidade em relação à questão da urbanização e da defesa dos interesses coletivos, somente em momentos de proximidade eleitoral, alguns candidatos se aproximam de um ou outro morador da favela, que em determinado momento já foi presidente da comunidade, a fim de conquistar eleitores. Assim como o personagem de Calvino, 
Quinto, a população não hegemônica da favela da Mandioca quer se salvar, possuindo a esperança de que a inserção no mesmo modelo de produção seja a solução. Contudo vale lembrar que:

A sociedade que modela tudo o que a cerca construiu uma técnica especial para agir sobre o que dá sustentação a essas tarefas: o próprio território. O urbanismo é a tomada da posse do ambiente natural e humano pelo capitalismo que, ao desenvolver sua lógica de dominação absoluta, pode e deve agora refazer a totalidade do espaço como seu próprio cenário.(DEBORD, 2006:112).

Resistir a este cenário que está sendo produzido em parceria com o setor público e privado, com o objetivo de reproduzir uma imagem de cidade mundial para São Paulo, é uma tarefa um tanto quanto difícil, quando o urbanismo se tornou estratégia de dominação e o território, produto de interesses de alguns. 


\section{Considerações Finais}

Ao iniciar a descrição e a localização do centro Berrini com a proposta de compreender como espacialmente se realiza a globalização econômica, tomando como referência o conjunto de edifícios espelhados e prateados junto à Marginal do Rio Pinheiros que, em sua construção buscam refletir um espaço homogêneo de modernidade, em uma aproximação inicial se revelou que uma suposta homogeneidade não existe.

Vimos que a ocupação dessa região remonta ao uso das águas do Rio Pinheiros pelo Grupo Light, aproveitando-se da oportunidade para se apropriar das terras e do valor agregado que suas obras trariam sobre a região. A não utilização por parte do DER das terras desapropriadas junto ao Córrego Água Espraiada permitiu a ocupação de famílias de baixa renda no local, com a construção de moradias precárias. Mais tarde, no final dos anos 70 , quando se verifica na cidade paulista o processo de desdobramento da centralidade de São Paulo, a empresa Bratke Collet, se apropria de boa parcela dessa área que naquele momento, em função de sua localização e distância do Centro da cidade tem o preço do solo baixo, se comparado às centralidades existentes na época e inicia a construção de um conjunto de edifícios voltados a abrigar escritórios do chamado Terciário Moderno, tanto para empresas nacionais quanto internacionais, atendendo uma nova demanda empresarial.

Com a Operação Urbana Faria Lima, que indicava o vetor sudoeste da cidade como o eixo de desdobramento da centralidade, portanto a região que seria priorizada por investimentos públicos e privados, a Berrini sofreu grande valorização.

Animados e com o auxílio do Poder Público (Gestão Maluf), um "pool" de empresários, na tentativa de valorizar seus investimentos, criou uma associação com cotas para a "indenização" e remoção da favela do Jardim Edith. Apesar do esforço, parte da favela permanece e resiste no local.

A possibilidade de se criar, por meio do espaço, um sobre valor aos investimentos imobiliários e financeiros é o movimento que está produzindo o 
espaço da Berrini, uma ação do mesmo processo que desdobrou a centralidade de São Paulo.

A região é bastante heterogênea com formas de ocupação bem diferentes como já relatamos ao longo da pesquisa, ainda que haja nos discursos oficiais e privados a tendência de se apresentar esse espaço como homogêneo. $O$ que ficou evidente é que existe um interesse econômico explícito, de grupos hegemônicos e do Poder Público, esforçando-se para que algumas áreas ou regiões nas denominadas cidades mundiais sejam produzidas de forma semelhante, com o objetivo de vender a cidade, atraindo fluxos de capital internacional.

Essa ação de se produzir centros mundiais "homogêneos" faz parte de uma tentativa em se potencializar a globalização econômica por meio do espaço. Nesse sentido a produção flexível da economia é um fator que contribuiu muito para a heterogeneidade do centro Berrini, criando possibilidades diferenciadas, como o contato constante com outros centros nacionais e internacionais sem a necessidade de contigüidade física, condição que era, até certo momento, impossível para os demais centros que são anteriores à década de 70, na centralidade de São Paulo.

Sua capacidade de concentração de atividades do Terciário Moderno, exigindo muita comunicação e contato entre os profissionais de diferentes centros que as realizam, em conjunto ou de maneira complementar, se concretiza utilizando avanços tecnológicos que permitem outras relações espaciais. A infraestrutura de acesso por meio do transporte público, linhas de ônibus e metrô, em relação ao Centro, por exemplo, ainda está sendo produzida, mas não foi e não é impedimento para o bom desempenho das atividades do Terciário Moderno nessa região.

O que permite o centro Berrini estar integrado à centralidade de São Paulo são as condições que os trabalhadores dos altos escalões dispõem de meios de transporte e de comunicações que permitem os deslocamentos de maneira rápida, muitas vezes com utilização de meios de transporte como helicópteros e o uso de tecnologias de comunicação instantânea com cabos de 
fibra ótica, celulares, satélite e computadores, fazendo com que as suas relações com o Centro se dêem em um nível diferenciado, que não depende da contigüidade física ou de ligações com vias ou eixos de transporte público, condição que era fundamental no período de produção fordista, que induziu durante muito tempo à produção do espaço na cidade.

Como a Berrini resulta da transição no ajuste do processo produtivo, tendo a ocupação e organização inicial do seu espaço sido induzida pelo modelo fordista e atualmente sua ocupação e reorganização são induzidas por um modelo flexível, a produção desse espaço urbano se torna muito complexa.

Desse modo a Berrini, simultaneamente, através dos esforços nas parcerias público - privadas e de alguns investimentos internacionais, passou a representar um centro "globalizado" na centralidade mundial que é São Paulo, mas permanece com os resíduos das relações e ocupações anteriores, como parte da favela e dos barracos do Jardim Edith.

A construção e sustentação de uma imagem de modernidade para o centro Berrini canalizam muitos recursos públicos em grandes obras como o Complexo Viário Real Parque, em detrimento das necessidades sociais emergentes como a construção de conjuntos populares para aqueles que habitam nas favelas dessa região.

Constatamos que a globalização da economia na Berrini não produziu um centro fragmentado, isolado da centralidade de São Paulo. O que a pesquisa demonstrou é o contrário, cada vez mais, para se sustentar, precisa que as demais áreas da centralidade, o próprio Centro, sejam revalorizadas como forma de atrair os públicos solventes internacional, que além dos negócios, consome e se interessa pela cultura local, sua história, arquitetura, gastronomia, etc.

A noção de espacialização das atividades econômicas e dos serviços, que no processo produtivo reorganiza constantemente o espaço desdobrando a centralidade e expandindo a área urbana, permitiu localizar a Berrini nesse processo, esclarecendo que a produção desse centro se deu no contexto de produção da cidade. Ao considerar o desdobramento da centralidade foi possível apontar um novo conflito sócio - espacial, que é produzido com o movimento da 
centralidade econômica alcançando e começando a englobar a periferia. Surge o problema: um centro global com uma periferia imediata.

O movimento que engendrou a produção da cidade de São Paulo é o mesmo que continua a produzir a globalização da economia e reproduz suas contradições e desigualdades, entre os agentes hegemônicos e os não hegemônicos e o uso do Poder Público. A produção do espaço na Berrini com mega-construções cria uma imagem espetacular com o objetivo de agregar valor e atrair investimentos, mas não resolve os problemas da periferia imediata, apenas desvia a atenção para o espetáculo.

Evidenciamos que os interesses tanto globais quanto locais dos agentes hegemônicos são os mesmos, de reprodução do capital e que a "globalização da economia precisa ser produzida", de maneira que o espaço se tornou uma mercadoria fundamental para garantir o lucro.

A localização, a infra-estrutura e as funções do lugar se tornaram estratégias que o poder hegemônico por meio das parcerias público - privadas consegue se apropriar ou fazer acontecer com as Operações Urbanas, como demonstramos com a Operação Urbana Consorciada Água Espraiada.

Percebemos que a ênfase dada, ao Complexo Viário Real Parque e as instalações da Rede Globo de Televisão nessa região, segue a receita que foi "vendida" por Borja e Castells de transformar a cidade em "mercadoria competitiva".

A concretização desse "espaço mundial", por parte dos agentes hegemônicos, não contempla a existência e a resistência na centralidade com relação aos considerados não hegemônicos, no entanto, eles permanecem nessa região, que sofre transformações intensas com o desdobramento da centralidade e da espacialização da globalização, evidenciando que a Berrini não é apenas o interesse de um grupo hegemônico ou não hegemônico, ou apenas do Poder Público, ou da localização, ou das funções terciárias modernas, é o resultado da complexidade do processo urbano em que "O espaço e a política do espaço ‘exprimem' as relações sociais, mas reagem sobre elas”. (Lefebvre, 2004:26 e 27). 
As entrevistas com moradores na favela da Mandioca revelaram que a influência do centro Berrini é muito forte e o desejo de participar desse processo de "modernidade" surge nas antenas parabólicas, nos celulares, na Lan House em meio aos barracos e no interesse cada vez maior nos cursos de informática.

Nesse processo de produção das relações e do espaço que é contraditório e desigual, constatamos que a permanência e a resistência da população não hegemônica nesse lugar se dá, freqüentemente, através do uso dos mesmos mecanismos dos agentes hegemônicos e do modelo produtivo que produziu a favela e suas desigualdades.

Está se tornando comum, por exemplo, a especulação sobre a ocupação do solo no interior da favela. Como houve um adensamento da ocupação com a construção de casas de alvenaria, as áreas mais precárias passaram a ser utilizadas por alguns que constroem barracos para serem vendidos; outra prática é a construção de garagens, junto ao Conjunto Cingapura, para serem alugadas. Dessa forma, viver na favela está se tornando mais caro e a idéia de propriedade do solo ganhando maior importância.

A propriedade é a maneira que a população local entende que os fará resistir na região, ou seja, buscam possuir a propriedade do solo urbano.

Esta pesquisa não se conclui, expõe um conflito sócio-espacial que precisa continuar a ser estudado, do encontro da centralidade econômica com a periferia.

A potência do pensamento que conduziu a pesquisa é de Lefebvre quando diz: "O centro só pode, pois, dispersar-se em centralidades parciais e móveis (policentralidade), cujas relações concretas determinam-se conjunturalmente" (2004:93).

A Berrini não é um centro isolado e não consegue ser global sem 0 Centro e a centralidade de São Paulo. 


\section{Referências Bibliográficas:}

ANTUNES, Arnaldo. As coisas. $3^{\text {a }}$ ed. São Paulo: lluminuras, 1996. ALVES, Glória da Anunciação. O uso do centro da cidade de São Paulo e sua possibilidade de apropriação. Tese de Doutorado, São Paulo: Departamento de Geografia da FFLCH-USP, 1999.

Cidade: espaço de revelação in CARLOS, Ana

Fani Alessandri (org.) Ensaios de geografia contemporânea Milton Santos: Obra revisitada. São Paulo: Editora da Universidade de São Paulo: Hucitec: Imprensa Oficial do Estado, 2001.

ARANTES, Otília Beatriz Fiori. Cultura e transformação urbana in PALLAMIN, Vera M. (org.) Cidade e cultura. São Paulo: Estação Liberdade, 2002.

ARANTES, Otília Beatriz Fiori. Uma estratégia fatal: a cultura nas novas gestões urbanas in ARANTES, Otília F.; VAINER, Carlos; MARICATO, Ermínia Maricato Cidade do pensamento único. $3^{\mathrm{a}}$ ed. Petrópolis, RJ: Vozes, 2002.

BERMAN, Marshall. Tudo que é sólido desmancha no ar: a aventura da modernidade. $17^{\mathrm{a}}$ reimpressão. São Paulo: Companhia das Letras, 2000.

BONDUKI, Nabil. Depoimento. In Espaço \& Debates Revista de Estudos Regionais e Urbanos. NERU, ano XVII - n $42-2001$.

BOURDIEU, Pierre. Efeitos de lugar. In BOURDIEU, P. (org.) A miséria do mundo, 3ª ed. Petrópolis: Vozes, 1999.

Contrafogos 2: por um movimento social europeu. Rio de Janeiro: Jorge Zahar, 2001.

BRAUDEL, Fernand. La dinamica del capitalismo. Primeira reinpresión. México: Fondo de Cultura Económica, 1993.

CALDEIRA, Teresa. Cidade de Muros: crime, segregação e cidadania em São Paulo. São Paulo, Editora 34/Edusp. 2003.

CALVINO, Ítalo. As cidades invisíveis. $2^{a}$ ed. São Paulo: Companhia da Letras, 2003.

A especulação imobiliária.Rio de Janeiro: Nova Fronteira, 1986. 
CARLOS, Ana Fani Alessandri. Espaço-tempo na metrópole: a fragmentação da vida cotidiana. São Paulo: Contexto, 2001.

. O espaço urbano: novos escritos sobre a

cidade. São Paulo: Contexto, 2004.

CASTELLS, Manuel. A sociedade em rede. $6^{a}$ ed. São Paulo: Paz e Terra, 2002.

CORDEIRO, Helena Kohn. A "cidade mundial" de São Paulo e o complexo corporativo do seu centro metropolitano. In : SANTOS, M. et al. O novo mapa do mundo : fim de século e globalização. $4^{a}$ ed. São Paulo : Hucitec, 2002.

CORRÊA, Roberto Lobato, CASTRO, Iná Elias de, GOMES, Paulo César da Costa. (Orgs.). Geografia: conceitos e temas. $4^{a}$ ed, Rio de Janeiro; Bertrand Brasil, 2002.

DEBORD, Guy. A sociedade do espetáculo. $8^{a}$ reimpressão. Rio de Janeiro: Contraponto, 2006.

DIÁRIO OFICIAL DA CIDADE DE SÃO PAULO. Plano Plurianual - PPA 20062009. Edição oํ 200,p. 181-216. São Paulo, 2005.

FERRARA, Lucrécia D'Aléssio. Olhar periférico: informação, linguagem, percepção ambiental. 2ª ed. São Pulo: Edusp, 1999.

FIX, Mariana de A. B. Parceiros da exclusão: duas histórias da construção de uma "nova cidade" em São Paulo: Faria Lima e Água Espraiada. São Paulo: Boitempo, 2001.

São Paulo cidade mundial: fundamentos financeiros de uma miragem. Dissertação de Mestrado, Departamento de Sociologia da FFLCH-USP, São Paulo, 2003.

FOUCAULT, Michel. Microfísica do poder. 18ª ed, Rio de Janeiro: Edições Graal, 2003.

FRÚGOLI, Heitor. Centralidade em São Paulo. São Paulo, Cortez Editora/Edusp, 2000.

FUJIMOTO, Nelson. A produção monopolista do espaço urbano e a desconcentração do terciário na gestão da cidade de São Paulo. $O$ caso da avenida Engenheiro Luís Carlos Berrini. Dissertação de Mestrado, São Paulo Departamento de Geografia da FFLCH-USP, 1994. 
HARVEY, David. Condição pós-moderna. $14^{\mathrm{a}}$ ed. São Paulo: Edições Loyola, 2005

A produção capitalista do espaço. $2^{a}$ ed. São Paulo:

Annablume, 2006.

GIDDENS, Anthony. As conseqüências da modernidade. São Paulo: Editora UNESP, 1991.

GIL, Gilberto. Todas as letras. São Paulo: Companhia da Letras, 1996.

KOK, Glória. São Paulo 450 anos: de vila a metrópole. São Paulo: BEI Comunicação, 2004.

LANGENBUCH, Juergen Richard. Depoimento. In Espaço \& Debates Revista de Estudos Regionais e Urbanos. NERU, ano XVII - n $42-2001$.

LEFEBVRE, Henri. La production de L'espace, Paris: Anthropos, 1986. . La presencia y la ausencia: contribución a la teoría de las representaciones. México: Fondo de Cultura Económica, 1993. . O Direito à cidade. $3^{\mathrm{a}}$ ed. São Paulo: Centauro, 2004. A revolução urbana. $2^{a}$ reimpressão. Belo Horizonte: Ed.

UFMG, 2004.

LENCIONI, Sandra. O processo de metropolização do espaço. Uma nova maneira de falar da relação entre metropolização e regionalização in SCHIFFER, Sueli (org.) Globalização e estrutura urbana. São Paulo: Hucitec: Fapesp, 2004.

MAGNANI, J. Guilherme C. De perto e de dentro. Revista Brasileira Ciências Sociais V. 17 n. 49 Sào Paulo jun. 2002.

MARICATO, Ermínia. As idéias fora do lugar e o lugar fora das idéias: planejamento urbano no Brasil in ARANTES, Otília F.; VAINER, Carlos; MARICATO, Ermínia Maricato. A cidade do pensamento único: desmanchando consensos. $3^{\text {a }}$ ed. Petrópolis, RJ: Vozes, 2002.

MARTINS, José de Souza. Depoimento. In Espaço \& Debates Revista de Estudos Regionais e Urbanos. NERU, ano XVII - n $42-2001$.

MARX, Karl. Capital, trabajo, plusvalía: conceptos basicos. Buenos Aires: Longseller, 1999. 
MOLES, Abrahan. Labirinto ou nebulosa in Espaces Temps. Voyage au centre de la ville: Eloge de I' urbanité, Espace Temps, 33, Paris: Association Espaces Temps,1986. (Tradução realizada pelo Laboratório de Geografia Urbana LABUR)

PESSOA, Fernando. Poemas. Seleção e introdução de Cleonice Berardinelli. Rio de Janeiro: Nova Fronteira,1985.

PRADO JUNIOR, Caio. A cidade de São Paulo: geografia e história. $1^{\text {a }}$ reimpressão, São Paulo: Brasiliense, 1998.

RONCAYOLO, Marcel. Diluição e implosão in Espaces Temps. Voyage au centre de la ville: Eloge de l' urbanité, Espace Temps, 33, Paris: Association Espaces Temps,1986. (Tradução realizada pelo Laboratório de Geografia Urbana LABUR)

ROSSI, Aldo. A arquitetura da cidade. São Paulo: Martins Fontes, 1998.

SANCHEZ, Joan-eugeni. Metropolização e modernidade in SANTOS, M.; SOUZA, Maria Adélia A.de; SCARLATO, Francisco Capuano; ARROYO, Mónica. $O$ novo mapa do mundo: fim de século e globalização. $4^{\text {a }}$ ed. São Paulo: Hucitec, 2002.

SANTOS, Milton. O espaço do cidadão. São Paulo: Nobel, 1987.

.Técnica, espaço, tempo. Globalização e meio técnicocientífico informacional.São Paulo: Hucitec, 1998.

SASSEN, Saskia. As cidades na economia mundial. São Paulo: Studio Nobel, 1998.

. Globalização da economia e as cidades in SCHIFFER, Sueli

(org.) Globalização e estrutura urbana. São Paulo: Hucitec: Fapesp, 2004.

SANTOS, Sergio Pinheiro dos. São Paulo: de colégio a cidade mesopotâmica.

Trabalho de Graduação Individual, São Paulo, Departamento de Geografia: FFLCH-USP, 2005.

SCARLATO, Francisco Capuano. Busca do centro - o reencontro com a cidade in CARLOS, Ana Fani Alessandri; OLIVEIRA, Ariovaldo Umbelino de (orgs.) Geografias de São Paulo: representação e crise da metrópole. São Paulo: Contexto, 2004. 
SEABRA, Odette C. L. Os meandros dos rios nos meandros do poder. Tietê e Pinheiros: valorização dos rios e das várzeas na cidade de São Paulo. Tese de doutorado, FFLCH-USP, São Paulo, 1987.

SOJA, Edward W. Geografias pós-modernas: a reafirmação do espaço na teoria social. Rio de Janeiro: Jorge Zahar, 1993.

SOMEKH, Nádia. Globalização e forma urbana: a intervenção urbanística na cidade de São Paulo. In : SANTOS, M. et al. O novo mapa do mundo: fim de século e globalização. $4^{\mathrm{a}}$ ed. São Paulo: Hucitec, 2002.

SPOSITO, Maria Encarnação Beltrão. "O centro e as formas de expressão da centralidade urbana" In: Revista de Geografia, v.10, Presidente Prudente: UNESP, 1991, pp.1-18.

TOURINHO, Andréa de Oliveira. Do centro aos centros: bases teóricoconceituais para o estudo da centralidade em São Paulo. Tese de Doutorado, Departamento da Faculdade de Arquitetura e Urbanismo da Universidade de São Paulo, São Paulo, 2004.

WIRTH, Louis. O urbanismo como modo de vida. In VELHO, O. (org.) O fenômeno urbano. Rio de Janeiro: Zahar, 1967.

Música:

A cidade in Chico Science e Nação Zumbi. Da Lama ao caos. Sony Bmg/Chaos. 1994. 